\title{
Archaeological Testing and Collecting at Choke Canyon Reservoir, Nueces River Project, Texas
}

Carl S. Weed

Center for Archaeological Research

Harry J. Shafer

Center for Archaeological Research

Follow this and additional works at: https://scholarworks.sfasu.edu/ita

Part of the American Material Culture Commons, Archaeological Anthropology Commons, Environmental Studies Commons, Other American Studies Commons, Other Arts and Humanities Commons, Other History of Art, Architecture, and Archaeology Commons, and the United States History Commons

Tell us how this article helped you.

This Article is brought to you for free and open access by the Center for Regional Heritage Research at SFA ScholarWorks. It has been accepted for inclusion in Index of Texas Archaeology: Open Access Gray Literature from the Lone Star State by an authorized editor of SFA ScholarWorks. For more information, please contact cdsscholarworks@sfasu.edu. 


\section{Archaeological Testing and Collecting at Choke Canyon Reservoir, Nueces River Project, Texas \\ Creative Commons License \\ (c) (1) \&}

This work is licensed under a Creative Commons Attribution-NonCommercial 4.0 International License 


\section{ARCHAEOLOGICAL TESTING AND COLLECTING AT CHOKE CANYON RESERVOIR, NUECES RIVER PROJECT, TEXAS}

By

Carol S. Weed and Harry J. Shafer

Report prepared by the

Anthropology Research Laboratory,

Texas A\&M University

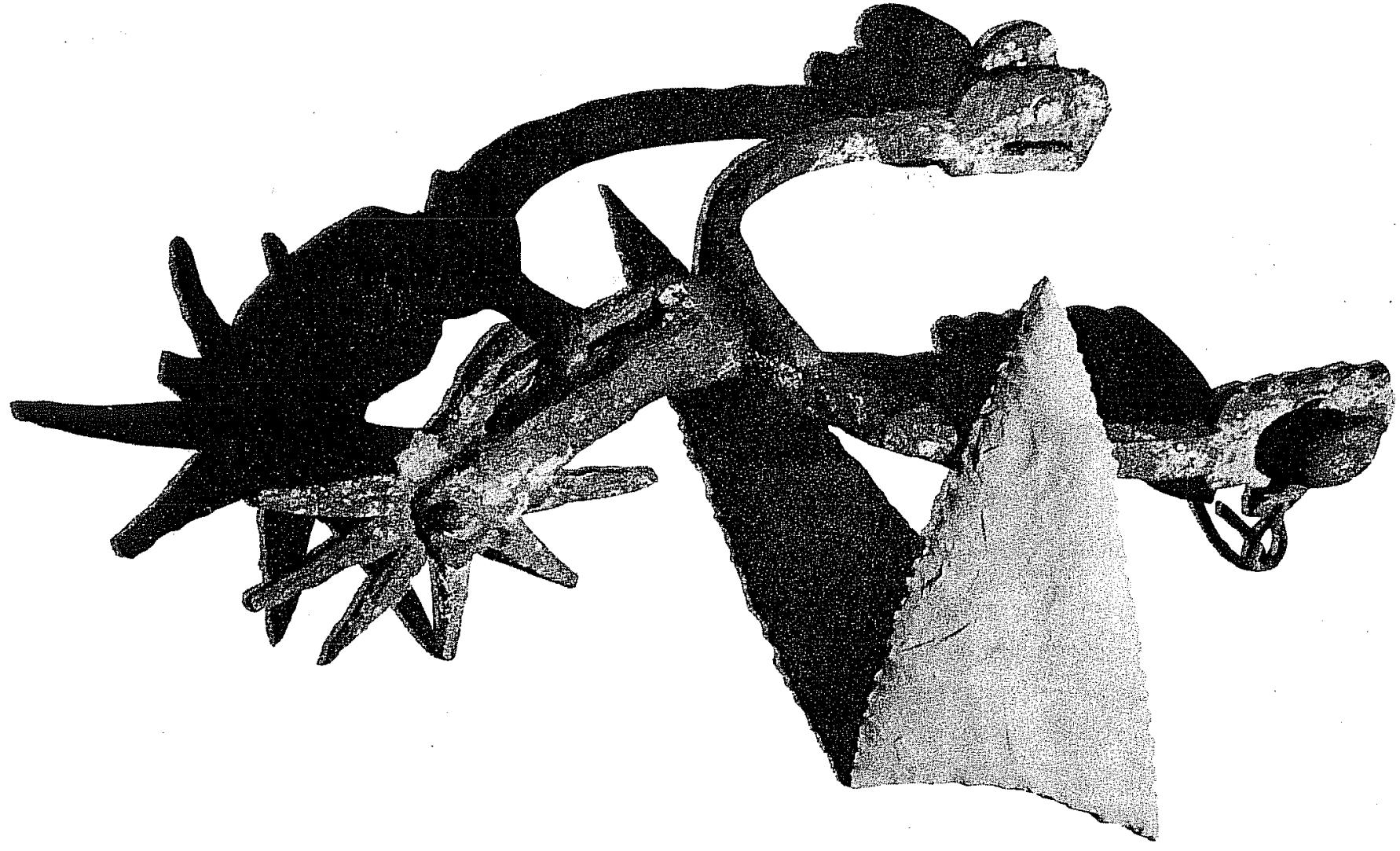

Center for Archaeological Research

The University of Texas at San Antonio

Choke Canyon Series: Volume 6 



\title{
ARCHAEOLOGICAL TESTING AND COLLECTING AT \\ CHOKE CANYON RESERVOIR, NUECES RIVER PROJECT, \\ TEXAS
}

Carol S. Weed and Harry J. Shafer

Report Prepared by the

\begin{abstract}
Anthropology Research Laboratory,
\end{abstract}
Texas A\&M University

Center for Archaeological Research

The University of Texas at San Antonio

6900 N. Loop 1604 West

San Antonio, Texas 78249-0658

Center for Archaeological Research

The University of Texas at San Antonio

Choke Canyon Series: Volume 6

1987 


\section{Center for Archaeological Research \\ The University of Texas at San Antonio}

78285

Thomas R. Hester, Director

Volumes in the Phase I Choke Canyon Series.

Volume 1 Historic Indian Groups of the Choke Canyon Reservoir and Surrounding Area, Southern Texas. By T. N. Campbell and T. J. Campbe11.

Volume 2 Part I - Historical Resources of the Choke Canyon Reservoir Area in McMullen and Live Oak Counties, Texas. By Dianna Everett.

Part II - Historical Archaeological Resources of the Choke Canyon Reservoir Area in McMulien and Live Oak Counties, Texas. By Philip A. Bandy.

Volume 3 An Archaeological Survey of a Portion of the Choke Canyon Reservoir Area in McMullen and Live Oak Counties, Texas. By Alston V. Thoms, John L. Montgomery, and Alice W. Portnoy.

Volume 4 The 1979 Archaeological Survey of Portions of the Choke Canyon Reservoir in Live Oak and McMullen Counties, Texas. By Erwin Roemer, Jr.

Volume 5 Archaeological Investigations at Choke Canyon Reservoir, South Texas: The Phase I Findings. By Grant D. Ha1l, Carol Graves, and Stephen L. BTack.

Volume 6 Archaeological Testing and Collecting at Choke Canyon Reservoir, Nueces River Project, Texas. By Carol S. Weed and Harry J. Shafer.

Volume 7 Excavations at 41 LK 67, A Prehistoric Site in the Choke Canyon Reservoir, South Texas. By Grant D. Hall.

Volume 8 Excavations at Sites 41 LK $31 / 32$ and 41 LK 202 in the Choke Canyon Reservoir, South Texas. By Robert F. Scott IV and Daniel E. Fox.

Volume 9 Phase I Archaeological Investigations at Choke Canyon Reservoir, South Texas: A Summary and Synthesis. By T. R. Hester and Grant D. HaTl.

NOTE: Titles of the above volumes are only tentative and may change at time of publication. 
This volume is Report No. 51 of the Texas A\&M Anthropology Laboratory 


\section{ABSTRACT}

This monograph reports the findings made during the summer of 1977 of test excavations and/or surface collections at 17 prehistoric archaeological sites in the Choke Canyon Reservoir area. The work was carried out by Texas A\&M University for the Center for Archaeological Research, The University of Texas at San Antonio. The field work was conducted to assess the archaeological potential of each site in order to advance recommendations for further investigations. The artifact samples, although meager, are described and these data are incorporated with other information from each site towards an overall site evaluation. Recommendations for further work are also included at the end of the report. 
TABLE OF CONTENTS

Page

ABSTRACT ...........................

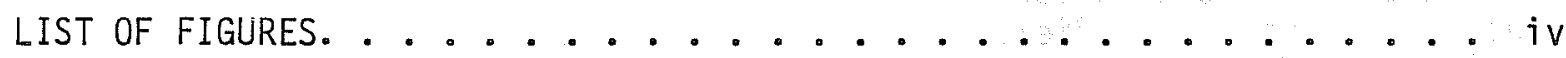

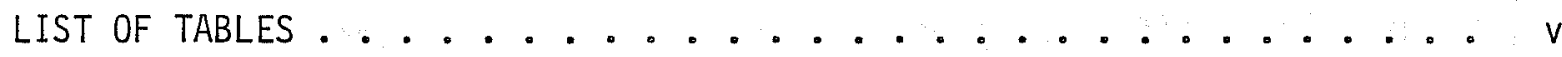

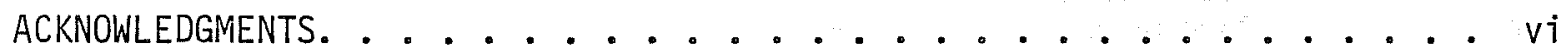

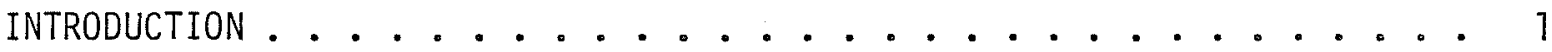

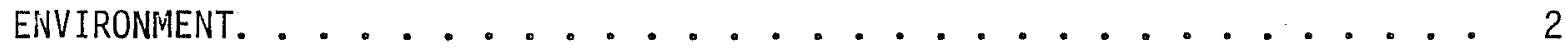

Local Physiography..................... 4

Geology ...................... 6

Hydrology ...................... 6

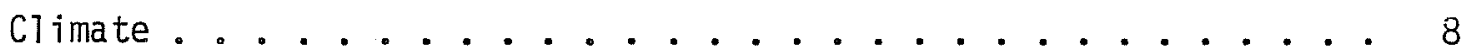

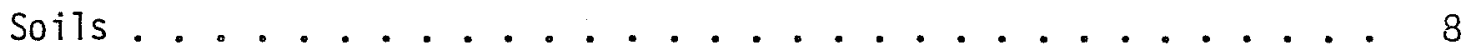

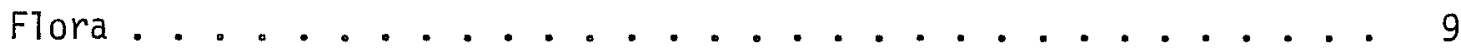

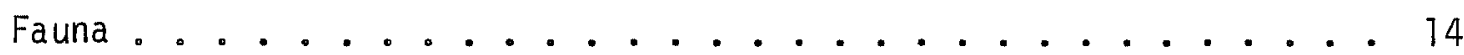

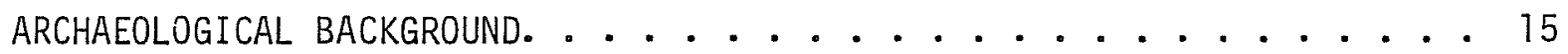

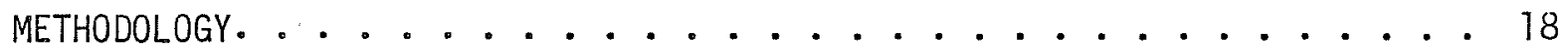

SITE DESCRIPTIONS. . . . . . . . . . . . . 20

41 LK 19......................... 20

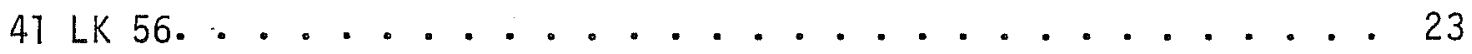

41 LK 90......................... 25

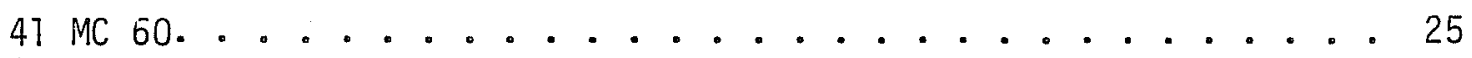

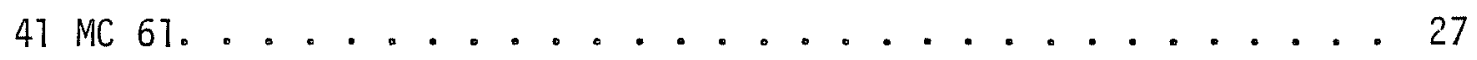

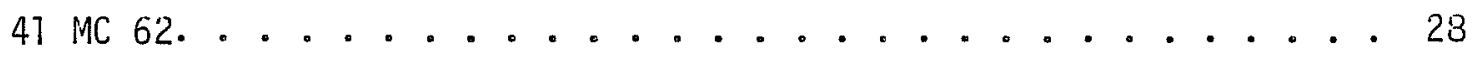

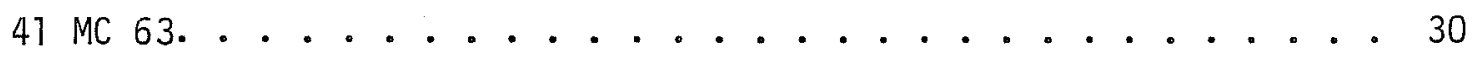

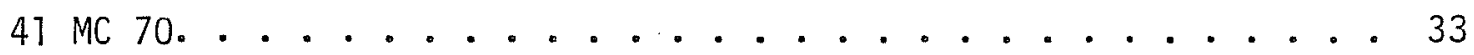




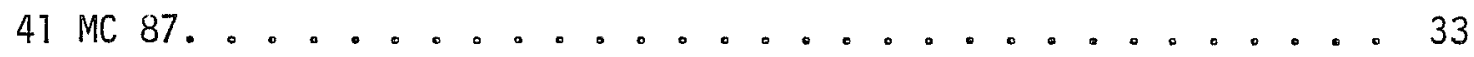

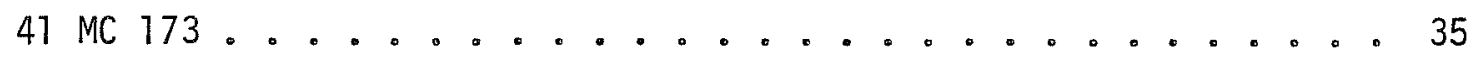

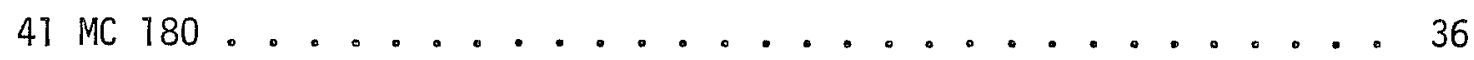

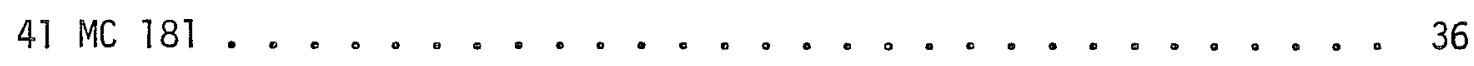

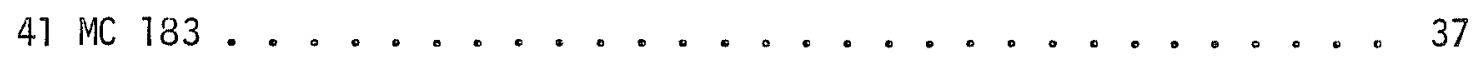

41 MC $184 \ldots \ldots \ldots \ldots \ldots \ldots \ldots \ldots$

41 MC $186 \ldots \ldots \ldots \ldots \ldots \ldots \ldots \ldots$

41 MC $187 \ldots \ldots \ldots \ldots \ldots \ldots \ldots . \ldots \ldots \ldots$

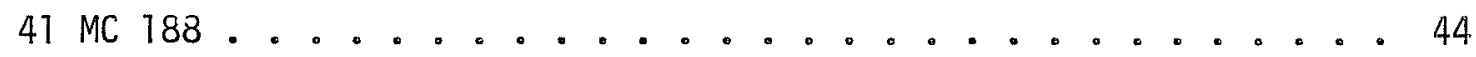

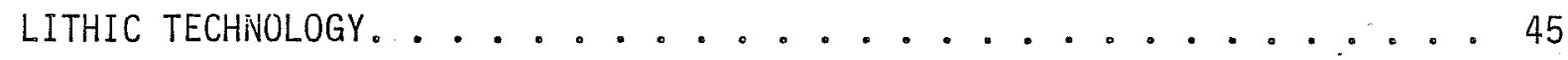

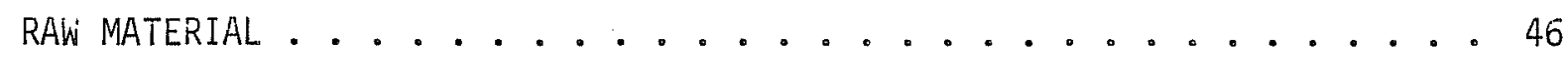

ARTIFACT DESCRIPTIONS. . . . . . . . . . . . 47

Biface Implements ................ 47

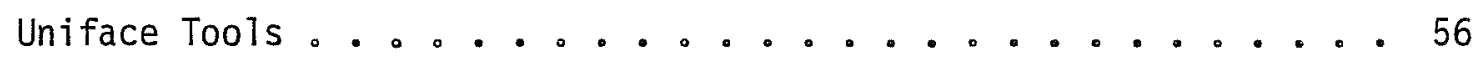

Miscellaneous Lithic Artifacts................ 58

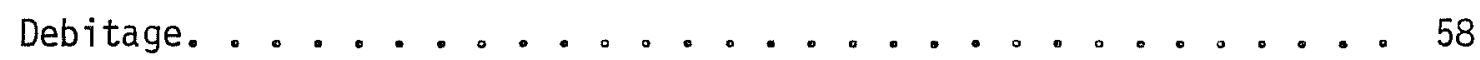

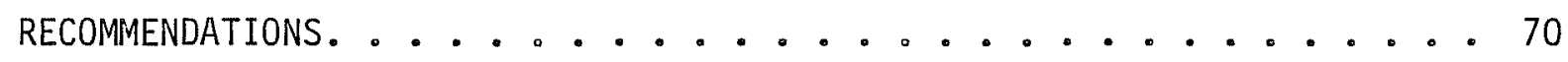

REFERENCES CITED ..................... 74 


\section{LIST OF FIGURES}

Page

1. Reservoir Map Showing Locations of Investigated Sites. ...... 3

2. Nueces River Drainage Network. . . . . . . . . . . . . 5

3. Surface Geology of South Central Texas . . . . . . . . . . 7

4. Vegetation Regions of South Central Texas. . . . ....... 10

5. Nueces River Project: Elm Creek/Frio River Complex........ 19

6. 41 LK 19 Site Map. .................... . . 22

7. 41 LK 56 Site Map. .................... 24

8. 41 LK 90 Site Map. . . . . . . . . . . . . . . . 26

9. 41 MC 62 Site Map. . . . . . . . . . . . . . . . . . 29

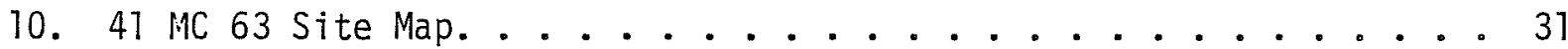

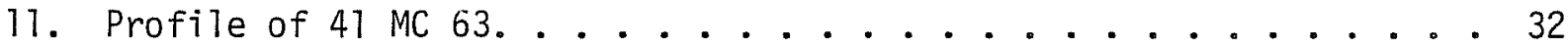

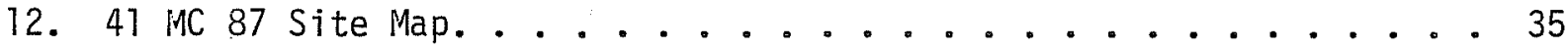

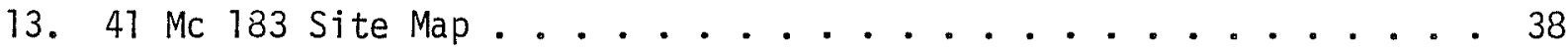

14. Site 41 MC 183, Location of Test Pits. . . . . . . . . . 39

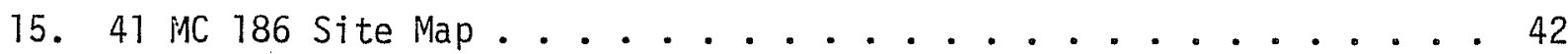

16. Biface Implements. . . . . . . . . . . . . . . . 50

17. Projectile Points. . . . . . . . . . . . . . . . 53

18. Uniface Tools. . . . . . . . . . . . . . 57

19. Biface Failures. . . . . . . . . . . . . . 65

20. Biface Failures. . . . . . . . . . . . . . 66 


\section{LIST OF TABLES}

Page

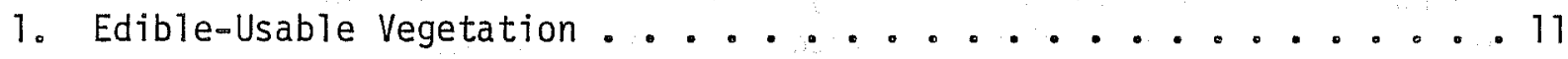

2. References to Southern Texas Archaeology ............ 15

3. Implements: Provenience and Metric Data ............ 48

4. Debitage, Biface Failures, and Cores: Provenience and Metric Data . . 60 


\section{ACKNOWLEDGMENTS}

The authors would like to express sincere appreciation to those individuals who put forth a special effort to aid and assist in this project. The field work was carried out under the direction and responsibility of Carol S. Weed, with the assistance of Kenneth J. Lord. Other crew members were Gordon McEwan, Johnny George, Ellen Murry, Joe Shafer, Tom Stearns and Hugh Sterns. Dr. Harry J. Shafer, the Principal Investigator, assumed overall project responsibility.

We wish to thank the Bureau of Reclamation, Nueces River Project personnel for their cooperation, especially Allen C. Gates and Bob Rowell who assisted the survey crews in providing land access for field work, we owe a special debt of gratitude.

The cooperation and patience of Dr. Thomas R. Hester, overall director of the Choke Canyon archaeological project, is also gratefully appreciated along with the invaluable assistance of Grant $\mathrm{Hall}$ who was field supervisor of the UTSA project. We would also like to express our thanks to Royce Mahula and Carol Graves for their patience and understanding. At TAMU, Anita Demirs, Sherry Keaton, Edie Schaffer, Phil Dering and John Ippolito all assisted in some way toward the completion of this study. While the assistance by the persons mentioned above, as well as others not listed, was most beneficial, any error of fact or interpretation is the authors'. 


\section{INTRODUCTION}

The Nueces River Project, developed by the Department of the Interior, Bureau of Reclamation, will lead to the construction of Choke Canyon dam and lake centered primarily along the middle and lower Frio River drainage. The water retained within the dam will be utilized by the Coastal Bend area, and the dam itself will "regulate the flow of the Frio River for municipal and industrial use" (Wakefield 1968:1) for the aforementioned region.

While initial archaeological survey of the reservoir area was conducted in 1967 (Wakefield 1968), fu11-scale survey operations did not commence unti 7 1974 when the Texas Historical Commission began two seasons of reconnaissance of the affected land, in an effort to accurately assess the prehistoric and historic resource potential of the region. Recommendations based upon the results of that work (Lynn, Fox, and O'Malley 1977) led to a multi-level series of investigations which will ultimately result in the full mitigation of selected sites within the reservoir boundaries.

The Anthropology Research Laboratory, under the auspices of the Texas A\&M Research Foundation, began work within the Choke Canyon Reservoir district in July 1977. Their role within the project was as a subcontractor to The University of Texas at San Antonio (UTSA), which is coordinating the Phase I cultural resource investigations of the recommended sites (Contract No. 7-0750-V0897). The Principal Investigator for the total project is Dr. Thomas R. Hester of the Center for Archaeological Research at UTSA and Dr. Harry J. Shafer served as Principal Investigator for the TAMU subcontract. Thirty field days were allotted by terms of the TAMU proposal to complete Intensive Testing of 12 sites. A crew of eight, divided into two crews under the direction of either Carol S. Weed or Kenneth J. Lord completed six sites prior to encountering access problems. A smaller crew returned to the area early in August to complete additional work.

The Phase I culture resource investigations, as outlined by the Bureau of Reclamation Scope-of-Work, encompassed the following objectives:

(1) testing and evaluating previously identified cultural resources in the project area;

(2) surveying those portions of the reservoir area which have not, to date, been inspected;

(3) making detailed recommendations for Phase II mitigation.

The field work deemed "necessary by the Bureau. . . in order to reach those goals" involves:

(1) intensive evaluation at three prehistoric sites in the dam and borrow pit areas;

(2) intensive testing of 12 sites and minimal testing of 36 additional sites, primarily for purposes of better evaluation; 
(3) surface collection at 64 prehistoric sites for purposes of better evaluation;

(4) intensive surface survey of 6000 acres not previously inspected for cultural resources;

(5) historic sites archaeology, involving testing at four sites and surface collections at six others.

The relative complexity of the objectives and the limited amount of time available for the complete mitigation of the cultural resources in the reservoir area demanded that the work load be divided. As originally outlined in the UTSA proposal, UTSA would be responsible for the intensive evaluation of the three sites, the minimal testing and surface collection segments, and the ethnohistoric research. Texas Tech University, the other subcontractor, was responsible for the historic sites archaeology and the supervision of the historical research, plus the completion of the survey. Texas A\&M was to conduct the intensive testing of 12 sites, 41 LK 13, 41 LK 19, 41 LK 51, 41 LK 85, 41 LK 87, 41 LK 90, 41 LK 94, 41 MC 63, 41 MC 75, 47 MC 87, 41 MC 183, and 41 MC 186. The following objectives were outlined for the scope of this work:

a. Conduct test excavations at each site to ascertain the vertical and horizontal limits of cultural materials.

b. Conduct investigations to ascertain the stratigraphic nature of the cultural materials at each site.

c. Recover cultural materials which could integrate the sites into the cultural, chronological and functional framework which is being established for the reservoir area.

d. Conduct investigations which will determine the eligibility of the sites for nomination to the National Register of Historic Places.

e. Conduct investigations which will result in the formulation of recommendations for Phase II, Mitigation.

The work was accomplished at on1y six sites, 41 LK 19, 41 LK 90, 41 MC 63, 41 MC 87, 41 MC 183, and 41 MC 186 during the first field session due to land access problems. Because of these access problems, arrangements were made to trade certain sites with the UTSA crew working under the direction of Grant Hall. Therefore, during the second field session, TAMU conducted minimal testing and/ or surface collections at the following sites: 41 LK 56, 41 MC 173, 41 MC 181, 41 MC 184, 41 MC 188, 41 MC 187, 41 MC 60, 41 MC 61, 41 MC 62, and 41 MC 70 (Fig. 1). Site 41 MC 180 was located but due to the virtual absence of cultural material, no collections were made. Site 41 LK 174 was inaccessible to the survey crew.

\section{ENVIRONMENT}

A general description of the environment for the Choke Canyon area is presented here as a necessary reference for the site discussions. More detailed 
Figure 1. Reservoir Map Showing Locations of Investigated Sites.

PAGE 15 REDACTED 
environmental studies are being conducted by UTSA and a general summary has already been presented by Lynn, Fox, and O'Malley (1977).

The Choke Canyon Reservoir lies about equal distance between the Balcones Escarpment and the Gulf of Mexico some 137 kilometers (85 miles) south of San Antonio. The immediate area is characterized by low rolling hills and thorny brush cover. Bounded on the east by the town of Three Rivers and on the west by Tilden, the reservoir boundaries are such as to essentially cut Live Oak and McMullen Counties in half. The Frio River meanders a basically west-toeast course through the reservoir area and is joined by the Atascosa River just west of Three Rivers, but east of the dam site.

The reservoir district lies in the physiographic region known as the Interior Coastal Prairies, a subdivision of the West Gulf Coastal Plain Physiographic Province (Fenneman 1938:102-103). The area within which the reservoir and dam are located is bounded on the east by the Bordas-Oakville Escarpment and on the west by the Nacogdoches Escarpment (Johnson 1931:136). An excellent description of the physiography and geology is presented in Lynn, Fox, and 0'Malley (1977:4-21) and need not be repeated in ful1 here. The major features that would influence the human adaptive patterns are, however, stressed.

\section{Local Physiography}

Lynn, Fox, and 0'Ma1ley (1977:7-18, Fig. 2) define five physiographic zones in the reservoir area: Floodplain, Pleistocene Terrace, Valley Wal1, Tributary, and Uplands. This Floodplain zone was subdivided into fossil and modern (active) units and consists of the low-level, post-Pleistocene terrace deposits of sands, clays, silts, and gravels. The Floodplain zone also incorporates the present and relict channels of the Frio River and its tributaries.

The Pleistocene Terrace remnants are located along the edges of resistant bedrock formations and are characterized by red-brown to red sandy clays, yellow clays, sand, and gravels. Lynn, Fox, and 0'Malley (1977:13) also note that these terrace remnants occur at elevations of 9-20 meters above the present Frio River channel. The surface areas vary from $1 \times 2 \mathrm{~km}$ to $1.6 \times 4.5 \mathrm{~km}$.

The Valley Wall zone consists of those relatively steep slopes of bedded geological deposits that have been cut through by the Frio system. Elevations range from 25-36.6 meters above the Frio channel. The exposed geological deposits include the Lipan, Whitsett, Frio, and Catahoula outcrops and provided ready access to such 1 ithic resources as sandstones, sittstones, and silicified wood to the aboriginal population.

The Tributary zone encompasses the named and unnamed drainages of the Frio River and San Miguel Creek. These drainages, which are typically deeply cut with steep valley walls, create environmental alternatives and resource locales for plant, anima1, and mineral resources.

The Uplands consist of the flat, unusually featureless plains that border the Frio River Valley dominated in uncleared segments by thorny brush vegetation. In prehistoric times they were most likely grasslands. The elevations range from 25-36.6 meters to over 52 meters above the Frio channel. 


\section{NUECES RIVER DRAINAGE NETWORK}

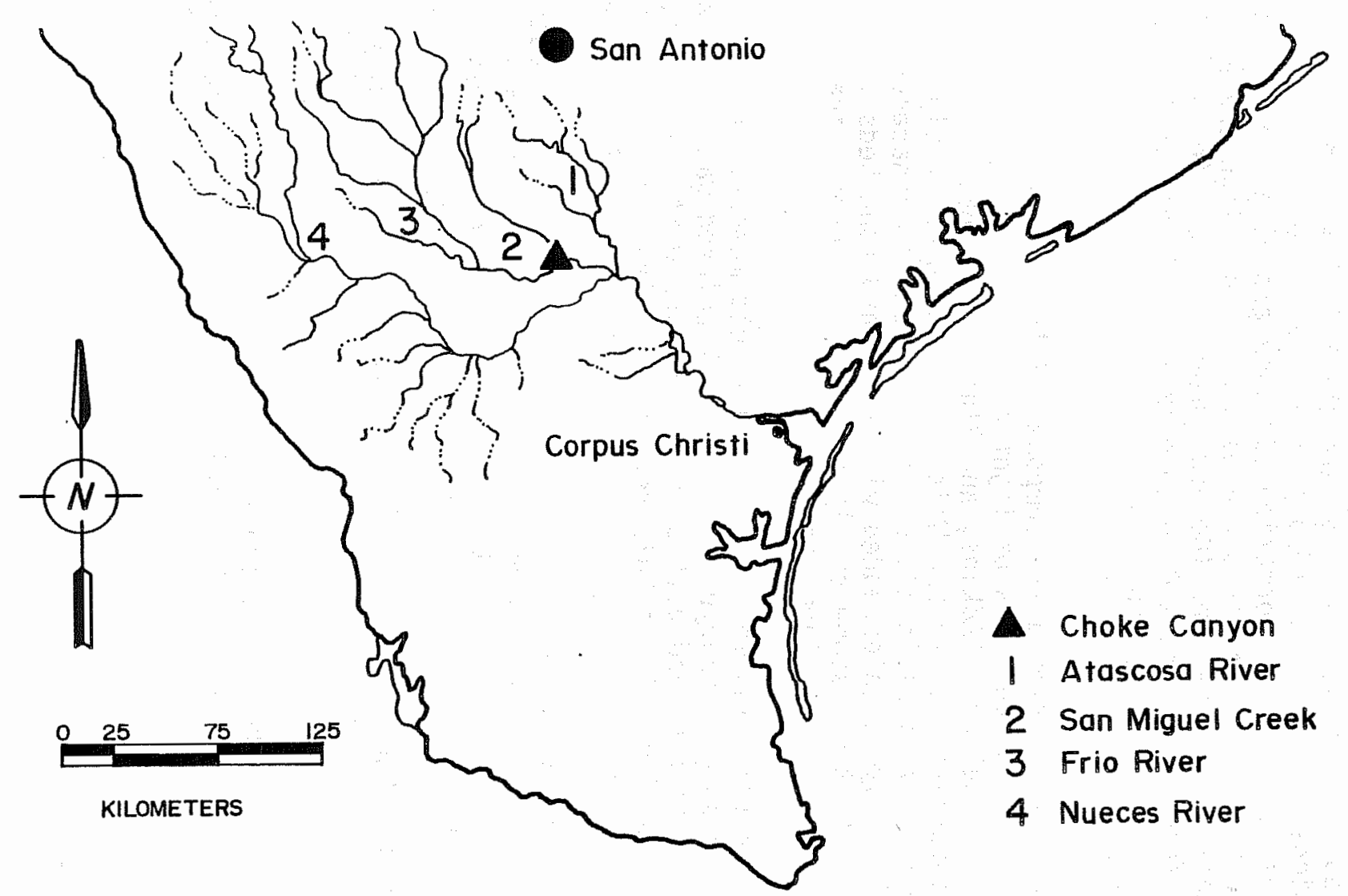

Figure 2. Nueces River Drainage Network. 


\section{Geology}

The Choke Canyon Reservoir area lies in the lower Frio River Valley (Fig. 2). The site of the reservoir is $16 \mathrm{~km}$ upstream from the confluence of the Nueces River and $6.4 \mathrm{~km}$ upstream from the confluence of the Atascosa River.

The general area slopes gently to the southeast. All geologic formations are sediments of tertiary age and the Frio River encounters three of these formations on its course through the area. These include one formation of Eocene age--the Fayette Formation (Jackson group) generally found in the western portion of the reservoir area and two of 0ligocene age (Fig. 3), the Frio and Catahoula formations (Geuydan group). The Frio is early 01igocene and the Catahoula is middle 01 igocene in age. Generally the above strata consist of shale, shalelike sandstone, tuff, siltstone, and a tuffaceous or bentonitic clay.

The Fayette strata are composed of "marine, brackish-water, near shore, and continental deposits of 1 ight colored sand, sandy clay, and green tuffaceous clay" (Se1lards, Adkins, and Plummer 1958:681) that have been divided into two members--the Lipan and Whitsett. The lower or Lipan formation consists of "a series of lignitic clays, volcanic ash, carbonaceous clays, and impure lignitic layers interbedded with thin sandstone beds . . ." (ibid.:686). A resistant sandstone cap layer limits the upper Lipan while the Yegua formation lies below this formation.

Above the Lipan member is the Whitsett member. These beds are composed of greenish-gray and yellow clay, dark-colored waxy carbonaceous clay, and sandy clays interbedded with gray, yellow and white sand (Sellards, Adkins, and Plummer 1958:867). This member is 1imited at its base by the upper sandstone of the Lipan and it is overlain by either the Frio or the Catahoula formations.

The Frio formation, when it outcrops, is usually a featureless plain (Frio Plain) consisting of greenish-gray clays that are interbedded by sandy clays of the Fayette at its base grading to a greenish-gray clay at the top of the formation. In the lake area the Frio is overlain by the Catahoula formation.

The Catahoula formation is composed of tuffaceous clays, volcanic conglomerates, sandstone, tuff, and volcanic ash (ibid.:716). It is the outcropping of the Catahoula that forms the "Choke" of Choke Canyon (Lynn, Fox, and O'Ma1ley 1977).

The sites themselves are in Quaternary deposits. These include Pleistocene outwashes and modern alluvial deposits from the Frio River and its tributaries containing varying amounts of clay, sand, and gravels (Sam Jett 1977, persona? communication).

\section{Hydrology}

The Choke Canyon Reservoir will successfully inhibit the flow of the Frio River, which currently drains an area of some 14,156 square kilometers. The Frio represents a major drainage system unto itself and is one of the three principal drainages for the southern Texas region, the other two being the Rio Grande 


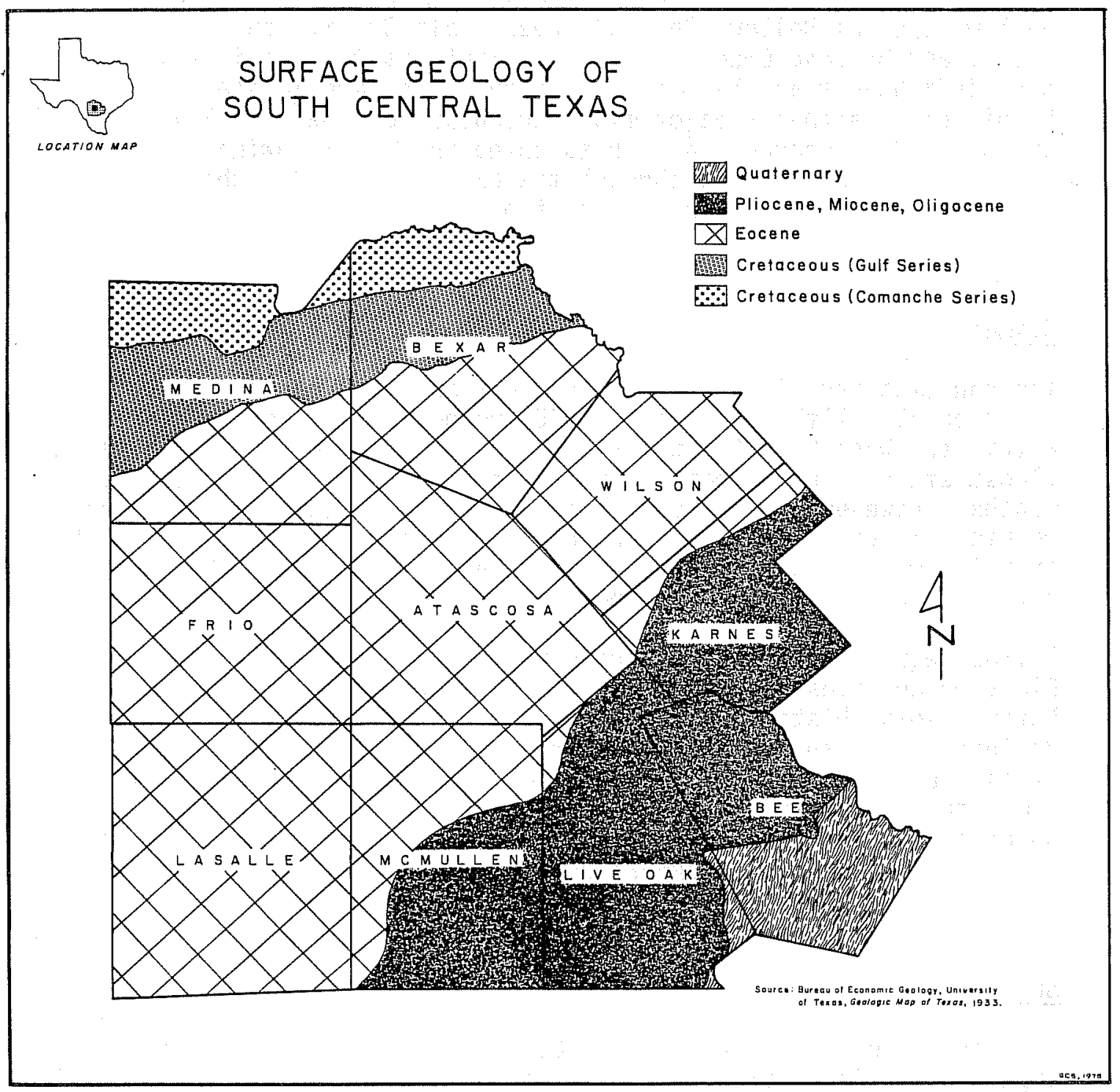

Figure 3. Surface Geology of South Central Texas. 
and Nueces Rivers. However, in addition, the Frio is the major tributary within the Nueces River drainage basin; the basin is characterized by a well-entrenched, dendritic network (Fig. 1) composed of up to Rank 6 named secondary streams.

The Frio River originates in Real County, northwest of the project area, in the Edwards Plateau as a spring-fed stream. It is soon joined by Hondo Creek and the Sabinal and Leona Rivers. Within the project area there are 11 major secondary tributaries to the Frio River, seven of which are named: Willow Hollow, Opossum. Hollow, Opossum Creek, Salt Creek, San Miguel Creek, Elm Creek, and Mustang Creek. Site distributions for the immediate project area have indicated that the majority of the sites are located within one half kilometer of either a major/minor tributary or the Frio River itself. This pattern is not unexpected, for as noted in the following Climate section, there is every indication that through the Late Prehistoric the majority of the streams were perennial in nature, though the overall climate was shifting to a more xeric pattern.

\section{Climate}

The contemporary climate of the project area has been described as semiarid and megatherma1. A1though Russel (1945) recognizes two major climatic divisions within the West Gulf Coastal Plain, the interior of the Plain maintains an almost steppe-like climate, with the dry season occurring during the winter months. However, the winter is not a period of complete dessication, as early morning fog banks and low-lying cloud formations off the Gulf of Mexico roll over the region, dissipating in the general vicinity of San Antonio. The region is generally given to hot and humid summers, with mild winters.

Pollen sequences from neighboring regions indicate that the climate in postPleistocene times was characterized by increasing aridity (Hester 1976:2). Nevertheless, historic accounts of the general area indicate that the major drainages, and their now intermittent tributaries, were perennially-flowing streams up until the early decades of this century (Hester 1975:109). At that time, the increasing numbers of cattle radically altered ground cover types, which greatly affected ground water levels. Concomitant with the introduction of large-scale ranching operations came deep well drilling to supply, for instance, increasing mining demands within the region.

Soils

McMullen County and a portion of Live Oak County belong to the Manteola-Monte11Zapata soil association. The formation is composed of clayey and loamy marine and deltaic sediments, with some stream and outwash alluvial clayey deposition (Godfrey, McKee, and Oakes 1973). Perhaps more important, however, is the fact that the soils fall into the vertisols class. Vertisols [which are also known as regur, black cotton soils, tropical black earths, margalitic soils or tersified soils (Butzer 1971:94)] are found mainly in locales on both margins of the lower latitude dry belt which are subject to seasonally waterlogged conditions. The upper portions of the formation are subject to an extremely high shrink-swell potential, and in all cases overlie an impervious bedrock or highly caliche 
subsoi1, in this case the Zapata formation. The nature of vertisols is such as to allow for the extreme displacement. of materials either within the soils or lying on top of the soils; for instance, severe building foundation displace: ment is apt to occur in localities where vertisols are present. What is seen on an archaeological level is a significant mixing of artifactual materials, resulting in a somewhat confused chronological patterning.

\section{Flora}

Live Oak and McMullen Counties lie within the Nuecian district of the Tamaulipan Biotic Province (B1air 1950:230-250). The predominant vegetational pattern now is a thorny brush woodland, with mesquite, various acacia, and prickly pear cactus dominating the region (Fig. 4). This pattern is slightly altered from that which has been present in the region since post-Pleistocene times. A11 indications point to a more savannah or steppe-like community, with the woody types restricted to riparian zones, principally along streams (Hester 1976:2).

Overgrazing has caused a change in this once dominant pattern; however, there is no evidence to indicate that any species currently in the region was not also present at time of contact, and probably before. Inglis (1964:69) notes, for example, that while mesquite may be a rather late introduction into the region, it nonetheless was present as early as 1691. What has occurred, obviously, is a shifting distributional pattern, and a higher incidence of certain species than was previously so. Michler in 1849 (Hester, White, and White 1969:132) noted that along creeks in nearby LaSalle County he encountered dense chapparal, but that away from the Frio River he observed a "fine, rolling prairie, which extended as far as the eye could see" (ibid.).

The exploitation of the savannah and the riparian zones by prehistoric populations is unquestioned. What remains in doubt is the extent, if at all, to which groups, either prehistoric or historic, could have exploited the resources of the region on a year-round basis. The Coahuilteco Indians are known to have taken advantage of the prickly pear tunas.* At least three Coahuilteco bands are known to have been in - the immediate vicinity of the project area from 1650 on, though not al1 were present necessarily simultaneously. Each was considered part of the Pachal cluster (Ruecking 1955:29) and included the Cacaxtle, Pajalat, and Pitalac bands. Actual territorial ranges for the three groups are not known, however both Newcomb (1961) and Campbe11 (1975) indicate that general seasonal rounds for the Coahuiltecos were confined to areas with an elliptical radius of no more than 80 miles.

The significant point is that such a range size would allow for maximum exploitation of more than one biotic zone, especially to the north where the groups would be encountering species present in the Balconian and Texas provinces. Listed in Table 1 is the plant list for the exploitable flora within the reservoir area proper taken from Vines (1960) and Kearney and Peebles (1960). As

*After this section was written, a review of ethnohistoric data for the Choke Canyon area was prepared by Campbe11 and Campbe11 1981. 


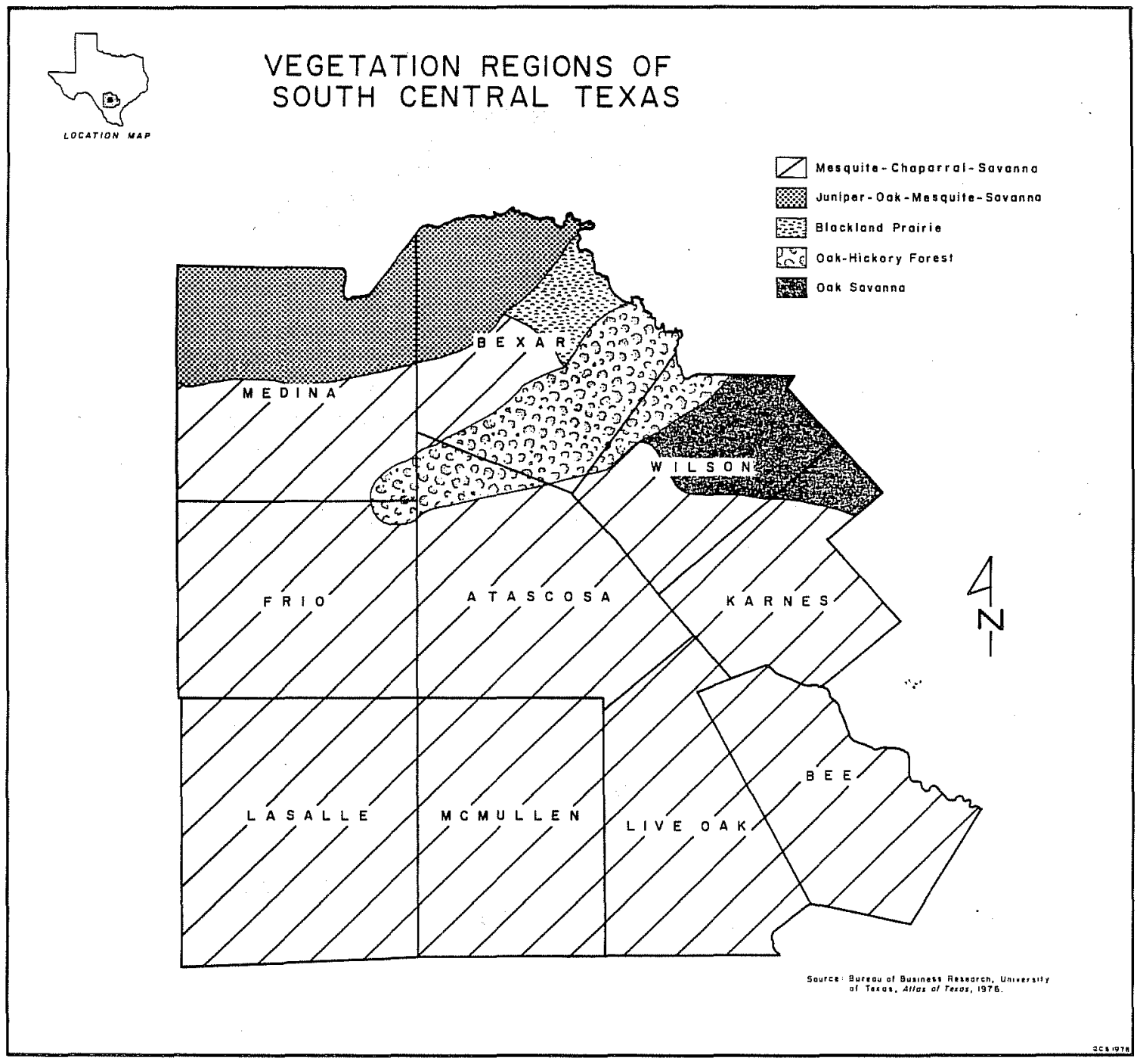

Figure 4. Vegetation Regions of South Central Texas. 
TABLE 1. EDIBLE-USABLE VEGETATION.

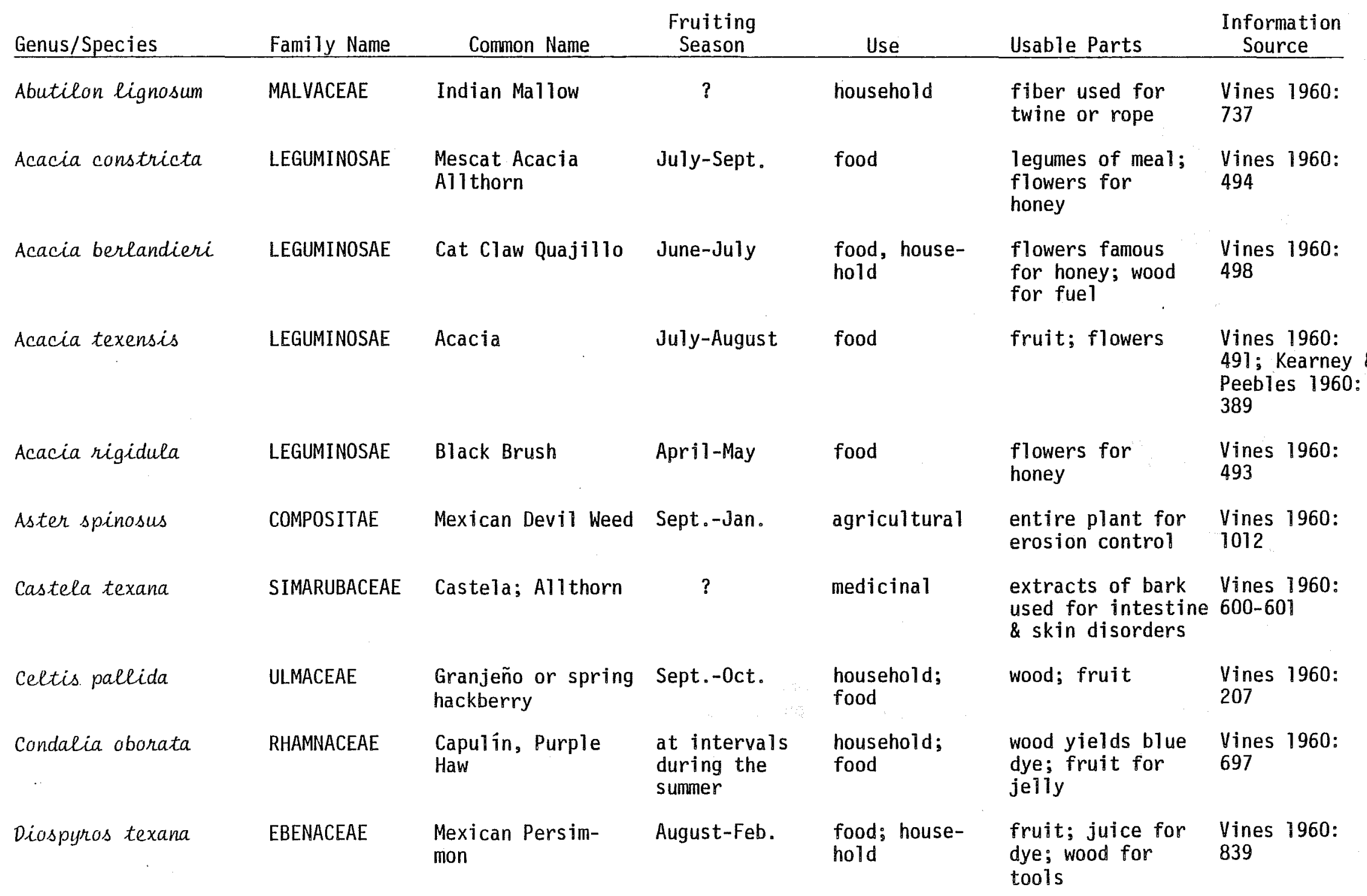


TABLE 1. (continued)

\begin{tabular}{|c|c|c|c|c|c|c|}
\hline Genus/Species & Family Name & Common Name & $\begin{array}{c}\text { Fruiting } \\
\text { Season }\end{array}$ & Use & Usable Parts & $\begin{array}{c}\text { Information } \\
\text { Source } \\
\end{array}$ \\
\hline $\begin{array}{l}\text { Ephedra anti- } \\
\text { syphilitica }\end{array}$ & EPHEDRACEAE & Clapweed & $\begin{array}{l}\text { Spring and } \\
\text { Early Summer }\end{array}$ & medicinal & $\begin{array}{l}\text { entire plant used } \\
\text { to treat syphilis }\end{array}$ & $\begin{array}{l}\text { Vines 1960: } \\
42-43\end{array}$ \\
\hline $\begin{array}{l}\text { Fraxinus } \\
\text { berlandieriana }\end{array}$ & OLEACEAE & Mexican Ash & May & household & wood & $\begin{array}{l}\text { Vines 1960: } \\
862\end{array}$ \\
\hline $\begin{array}{l}\text { Gymnosperma } \\
\text { glutinosum }\end{array}$ & COMPOSITAE & Talalencho & March-Dec. & medicinal & $\begin{array}{l}\text { entire plant used } \\
\text { to treat diarrhea }\end{array}$ & $\begin{array}{l}\text { Kearney \& } \\
\text { Peebles 1960: } \\
851\end{array}$ \\
\hline $\begin{array}{l}\text { Leucophyelum } \\
\text { frutescens }\end{array}$ & SCROPHULARIACEAE & $\begin{array}{l}\text { Cenizo Texas } \\
\text { Silverleaf }\end{array}$ & $?$ & medicinal & $\begin{array}{l}\text { flowers used to } \\
\text { treat fever \& } \\
\text { chills }\end{array}$ & $\begin{array}{l}\text { Vines 1960: } \\
920-921\end{array}$ \\
\hline Mimosa biuncifera & LEGUMINOSAE & Mimosa & Sept. & food & honey from flowers & $\begin{array}{l}\text { Vines 1960: } \\
507-508\end{array}$ \\
\hline opuntia lindheimeri & CACTACEAE & Prickly Pear & April-June & $\begin{array}{l}\text { food; } \\
\text { medicinal }\end{array}$ & fruits; narcotics & $\begin{array}{l}\text { Vines 1960: } \\
775\end{array}$ \\
\hline $\begin{array}{l}\text { Porliera } \\
\text { augustifolia }\end{array}$ & ZYGOPHYLLACEAE & $\begin{array}{l}\text { Guayacán; } \\
\text { Soap-bush }\end{array}$ & $?$ & $\begin{array}{l}\text { household; } \\
\text { food; } \\
\text { medicinal }\end{array}$ & $\begin{array}{l}\text { roots for soaps; } \\
\text { fruit for honey; } \\
\text { extract of root } \\
\text { for treatment of } \\
\text { veneral disease } \\
\text { and rheumatism }\end{array}$ & $\begin{array}{l}\text { Vines 1960: } \\
575\end{array}$ \\
\hline Prosopis julifeora & LEGUMINOSAE & Mesquite & $\begin{array}{l}\text { Late Summer- } \\
\text { Early Autumn }\end{array}$ & $\begin{array}{l}\text { food; } \\
\text { household }\end{array}$ & fruit; bark \& root & $\begin{array}{l}\text { Kearney \& } \\
\text { Peebles 1960: } \\
402\end{array}$ \\
\hline Quercus virginiana & FAGACEAE & Live 0ak & Spring & $\begin{array}{l}\text { food; } \\
\text { household }\end{array}$ & $\begin{array}{l}\text { bark for producing } \\
\text { tannin; acorn oil } \\
\text { for cooking; } \\
\text { excellent wood } \\
\text { source }\end{array}$ & $\begin{array}{l}\text { Vines 1960: } \\
170-171\end{array}$ \\
\hline
\end{tabular}




\begin{tabular}{|c|c|c|c|c|c|c|}
\hline Genus/Species & Family Name & Common Name & $\begin{array}{c}\text { Fruiting } \\
\text { Season }\end{array}$ & Use & Usable Parts & $\begin{array}{l}\text { Information } \\
\text { Source } \\
\end{array}$ \\
\hline Rhis microphylla & ANACARDIACEAE & Desert Sumac & May-July & food & fruit & $\begin{array}{l}\text { Vines 1960: } \\
637\end{array}$ \\
\hline Rivina humilis & PHYTOLACCACEAE & $\begin{array}{l}\text { Pigeon-berry } \\
\text { Pokeberry }\end{array}$ & June-0ct. & $\begin{array}{l}\text { household; } \\
\text { food }\end{array}$ & $\begin{array}{l}\text { leaves for dye; } \\
\text { fruit }\end{array}$ & $\begin{array}{l}\text { Vines 1960: } \\
253\end{array}$ \\
\hline Salix nigra & SALICACEAE & Black Willow & May-June & household & wood & $\begin{array}{l}\text { Vines 1960: } \\
95\end{array}$ \\
\hline $\begin{array}{l}\text { Salvia ballotae- } \\
\text { flora }\end{array}$ & LABIATAE & $\begin{array}{l}\text { Shrubby Blue } \\
\text { Sage }\end{array}$ & $\begin{array}{l}\text { Throughout } \\
\text { Summer }\end{array}$ & food & $\begin{array}{l}\text { leaves used for } \\
\text { flavoring }\end{array}$ & $\begin{array}{l}\text { Vines 1960: } \\
903\end{array}$ \\
\hline $\begin{array}{l}\text { Shaefferia } \\
\text { cunefolia }\end{array}$ & CELASTRACEAE & Desert Yaupon & $?$ & medicinal & $\begin{array}{l}\text { root used to } \\
\text { treat veneral } \\
\text { disease }\end{array}$ & $\begin{array}{l}\text { Vines 1960: } \\
666\end{array}$ \\
\hline $\begin{array}{l}\text { Talinum } \\
\text { aurantiacum }\end{array}$ & PORTULACACEAE & $\begin{array}{l}\text { Orange Flame } \\
\text { Flower }\end{array}$ & $?$ & food & root & $\begin{array}{l}\text { Kearney \& } \\
\text { Peebles 1960: } \\
286\end{array}$ \\
\hline Ulmus crassifolia & ULMACEACE & Cedar Elm & Late Summer & household & wood & $\begin{array}{l}\text { Vines 1960: } \\
210\end{array}$ \\
\hline
\end{tabular}


indicated on Table 1, the fruiting and harvesting seasons of many of the species overlap, allowing for continuous exploitation of this one province over an extended period of time. This is not to say that the groups did not range over the larger potential use area, but that they possessed the option of not necessarily having to continually move, as is usually indicated for southern interior groups.

Fauna

Obviously an interrelated, integral portion of any discussion of the environment of a region is the identification of the various faunal species which interdigitate with the floral communities. Blair, creating his biotic provinces of Texas, weighs the floral and faunal assemblages equally in his definitions. Therefore, the occurrence of various animal species utilizing a specific region on a general basis helps to define the character of that region. The Tamaulipan Biotic Province contains some 62 mammalian species alone and according to Blair ". - has a greater diversity of faunal elements than any other in Texas" (B1air 1950:249).

The significance of the variety of faunal types is emphasized by the fact that the Tamaulipan Province represents the eastern extent of many mammal species whose original home ranges were in Mexico. While there is some question whether or not the Nuecian district, or the entire Tamaulipan Province, represents an actual ecotone as defined by Odum (1971:157-159), nonetheless it is known that the province conforms to one portion of the definition, increasing variety and density in terms of either plant and/or animal species.

Indications are that as early as the Middle and Late Pleistocene the environment of the Rio Grande Plain was more savanna or "parkland" in type (Hester 1976:2). The reported occurrence of both mastodon and mammoth in southern Texas reinforces the notion of both savanna and possibly more diverse riparian woodland communities, the latter ideal foraging habitats for mastodon. The resulting disappearance of both species is probably the result of several factors. Increasing aridity definitely affected the floral communities present in the overall area, but to a relatively limited extent.

At least two species, both grassland habitat specific, are known to have been present in the region prehistorically, but post-Pleistocene: bison and antelope (Hester and Hil1 1975:17). These two were present up through the Late Prehistoric period, and their current absence from the region is probably indicative of the more radical change from open savanna grassland to thorny brush woodland which has occurred only over the last 400 years. Obviously, man's influence has also affected the bison, but that cultural factor may have had less to do with the disappearance of the species in this particular area than the environmental changes which greatly affected the nature of the foraging localities. 


\section{ARCHAEOLOGICAL BACKGROUND}

Southern, interior Texas has only within the last 20 years begun to take on a regional archaeological identity of its own. What has been found to date indicates a long period of utilization of the region, beginning as early as PaleoIndian and concluding during the historic period. Southern, interior Texas covers the following counties: Maverick, Zavala, Dimmit, Frio, LaSalle, Atascosa, McMul len, Live Oak, Jim Wells, Duval, Jim Hogg, Brooks, Starr, Hidalgo, Zapata, and Webb (Hester, White, and White 1969:131), and is commonly referred to in the literature as Southwest Texas. It is bordered on the west by the Rio Grande River, on the north by the Edwards Plateau, on the south by the Rio Grande delta, and on the east by the central and southern Texas coast. While the area becomes slightly more rugged and dissected, the essential outline remains remarkably similar throughout the region. Most of the area falls within the Tamaulipan Biotic Province, although several localities, especially toward the west and north, merge with adjacent provinces.

The earliest summary statement for the region was written by E. B. Sayles (1935). He placed the entire region into his "Coahuiltecon Branch," and emphasized the extremely rudimentary nature of the cultural remains which had been identified to date. Sel1ards (1940), Evans (1941), and Weir (1956) al1 reported on specific sites within the region, but restricted what little interpretation there was to an attempt in estabijishing the sites within chronological frameworks developed for either coastal or central Texas. Suhm, Kreiger, and Jelks (1954:134-143) did much to clarify the picture by describing previously unpublished work, and placing the chronological situation within an acceptable panTexas categorization. Their synthesis tended to point up the glaring gaps in the knowledge available on the archaeology of the region.

Since 1960 archaeological investigations in southern, interior Texas have multiplied and publications have increased. An exceptionally cogent discussion of previous work was done by Nunley and Hester (1975) and will only be briefly reviewed here. The publications to date fall into four major categories, with additions of work not available at the time of publication of the Nunley and Hester monograph, or not cited therein, are listed in Table 2 below:

TABLE 2. REFERENCES TO SOUTHERN TEXAS ARCHAEOLOGY.

Report Type Author (s)

Date

Specific Area

Site Reports

Hester, White, and

1969

White

Hester and Parker

1970

1971

Hi1l and Hester

Hester

1971

Oulline site (LaSalle County)

Berclair site (Goliad County)

Honeymoon site (Zavala County)

La Jita site (Uvalde County) 
TABLE 2. (continued)

\begin{tabular}{|c|c|c|c|}
\hline Report Type & Author(s) & Date & Specific Area \\
\hline \multirow{7}{*}{$\begin{array}{l}\text { Regional and } \\
\text { Reservoir Basin } \\
\text { Surveys }\end{array}$} & Nun1ey and Hester & 1966 & Dimmit County \\
\hline & Wakefield & 1968 & Choke Canyon \\
\hline & Fox et al. & 1974 & Cuero I Reservoir \\
\hline & Patterson and Ford & 1974 & $\begin{array}{l}\text { Oso Creek Flood } \\
\text { Control }\end{array}$ \\
\hline & Nunley and Hester & 1975 & Starr County \\
\hline & Shafer and Baxter & 1975 & $\begin{array}{l}\text { Atascosa and } \\
\text { McMullen Counties }\end{array}$ \\
\hline & Lynn, Fox, and O'Malley & 1977 & Choke Canyon \\
\hline \multirow{3}{*}{$\begin{array}{l}\text { Prehistoric } \\
\text { Technologies }\end{array}$} & Hester and $\mathrm{Hill}$ & 1971 & Ceramic \\
\hline & Hester and Shafer & 1971 & Lithic \\
\hline & Hester & 1975 & Lithic \\
\hline \multirow[t]{5}{*}{ Syntheses } & $\begin{array}{l}\text { Hester, White, and } \\
\text { White }\end{array}$ & 1969 & Southern Texas \\
\hline & Hester & 1976 & $\begin{array}{l}\text { Rio Grande Plain } \\
\text { Lower Coast Texas }\end{array}$ \\
\hline & Hester and $\mathrm{Hill}$ & 1975 & Southern Texas \\
\hline & Nunley and Hester & 1975 & Southern Texas \\
\hline & Hester & 1980 & Southern Texas \\
\hline
\end{tabular}

Obviously, Table 2 in no way reflects all the work done in southern, interior Texas, nor does it include those reports which have apparent cross-regional pertinence. The gathering of data within the region has led to a series of generalized conclusions concerning settlement patterns, chronological placement of sites, subsistence patterns, and technology. The first of these to be discussed will be the chronological framework which, though still tentative, has led to a temporal reality for the area. 
The accepted, and most operable, temporal framework for the region is based on the Suhm, Krieger, and Jelks (1954) categorization: Paleo-Indian, Archaic, and Neo-American (Late Prehistoric). This system is the basis for all temporal interpretation in Central, Coasta1, and Southwest Texas. The horizon markers within the framework are differing projectile point types, plus the addition of secondary trait information. The three stages, nonetheless, represent a temporal continuum, with the major change occurring between the Late Archaic and the Neo-American stages when the bow and arrow and, probably later, ceramics are introduced into the region. Of the three stages, the Paleo-Indian is the least we11-defined but is represented by numerous surface finds (see Hester 1977 for a discussion of these early assemblages). The subsequent Archaic is divided into three periods: Early, Middle, and Late. The Neo-American follows the Late Archaic, with the former in reality lasting into the post-contact period. While the framework may upon first perusal seem elementary, it becomes increasingly complex due to the regional variation of the horizon markers, and the lack of absolute dates for the majority of the region.

For instance, Johnson (1967), performing a statistical analysis of material remains from nine sites in the central and lower Pecos areas of Texas, determined that for a period of some 5000 years no significant comparison could be made between the assemblages, even though all fell well within accepted definitions and time ranges for Early or Middle Archaic. The dichotomous nature of the assemblages for those nine sites (Roark, Centipede, Coontail Spin, Devil's Mouth, Wunderlich, Oblate, Levi-Fox, Smith, and Kyle) is reflective of the amount of variation identified throughout the region. While the assemblages possess basically the same components, the number of varieties of diagnostic artifact types is extreme.

Part of the problem is in the nature of the diagnostic artifacts. Johnson (1967:14) points out that it is ". . . always the projectile points (usually their bases or stems) which show the greatest elaboration and variability." However, it is this very variability which makes it so difficult to classify the artifacts with consistency. No other class of artifacts within the lithic spectrum appears to have the time sensitivity as the projectile points. Scraper and knife styles have been shown to be relatively consistent throughout a long period of time and are therefore "unsuitable for delimiting short depositional, and hence temporal, intervals" (ibid.). The other problem lies in the fact that the majority of the sites worked in the region have been multi-component sites, which have with consistency displayed mixed depositional sequences. The presence of vertisols, plus the fact that many of the sites are located in floodplain or first terrace situations, has led to mixing within the vertical sequences. On a horizontal level, localities have been shown to have been utilized repeatedly over lengthy spans.

The latter point is one of some concern. Settlement pattern studies within the various reservoir or regional surveys have shown that while there are basic patterns in site placement, again it is highly variable from locality to locality. Overall patterning for the region has been reduced to the following:

Late Prehistoric sites are concentrated in riparian microenvironments on the banks of large creeks (or the Nueces River and its former channels). Some sites of this period do occur in the floodplainriparian ecotone. The settlement distribution of the earlier 
Archaic and Paleo-Indian periods is inadequately known. Some late

Prehistoric remains in the riparian zone; other Archaic sites are found in mid-floodplain and on the bordering uplands. Early

Archaic and Paleo-Indian are most commonly found at sites scat-

tered along high terraces or upland fringes (Hester and Hil1 1975:7).

This is not to imply that the research which has gone into such studies has been inadequate; 'it is meant to point up the fact that the lack of site depth, temporal control and large scale excavations has significantly impeded the progress of such studies within the region.

It has been emphasized repeatedly that sites in southern Texas are characterized by a lack of cultural associations. While this may be a function of sampling, nonetheless the sites excavated to date in the region have shown a remarkable dearth of hearths, living floors, etc. Therefore, the characterization of the sites is based principally upon size, locality (to a lesser extent) and temporal placement, which in more cases than not, cannot be isolated to one specific period. Settlement pattern studies, subsequently, in the region, are virtually nullified before they begin because of a lack of sufficiently stringent chronological control upon which to base conclusions. Models, to be presented in the subsequent section, will attempt to take the various environmental data available and, by viewing it in three differing interrelational networks, supply some clue as to possible settlement and subsistence strategies.

Subsistence strategies for the region have been primarily inferred, because of an insufficiency of faunal and ethnobotanical data. What has been recovered indicates an exploitation of rabbit, deer, and small rodents. In addition, the utilization of various land snails (Rabdotus sp.), bivalves (mussel), and reptiles has been demonstrated. What has not been recovered is information on the economic use of plants. Based on recent findings in south Texas (Shafer and Bryant 1977; Dering and Shafer 1976; Dering 1979), and from information provided by the narratives of the travels of Cabeza de Vaca (Kreiger 1956), plant foods predictably served as the mainstay of the diet.

\section{METHODOLOGY}

The sites, both to be minimally tested and/or surface collected were investigated using standard archaeological procedures and controls. All material was screened through a 1/4-inch mesh, or smaller in some instances. Soil and pollen samples were systematically collected. Site size determinations, however, proved a difficult task. Unusually dense vegetation, ownership problems, and errors in original assessment prohibited the development of accurate site-contour data.

At each site, an effort was made to identify to as great a degree as possible the boundaries as originally set by the Texas Historical Commission survey (Lynn, Fox, and 0'Malley 1977:104-108). In certain instances, arroyo cutting, plowing, or seasonal variations in vegetation had obliterated or obscured the boundaries as defined. In those instances, new boundaries were set (Fig. 5). After determining the boundaries, permanent datum and north-south and eastwest transect lines were set across the sites dividing them into four quadrants. Depending on the size of the quadrants, either transect lines or random $4 \mathrm{~m}^{2}$ units were utilized in order to surface-collect each site. If the sites were 
Figure 2. Nueces River Project: Elm Creek/Frio River Complex.

\section{PAGE 31 REDACTED}


to be tested, units within the collection areas were excavated. Units were located by grid coordinates and can be relocated from the permanent datum.

A11 site data was taken to Texas A\&M University for processing and will ultimately be curated at the Center for Archaeological Research at San Antonio. Initially the excavation units were $2 \mathrm{~m}^{2}$, however later, because of 1 imited returns, $1 \mathrm{~m}^{2}$ units were excavated in an effort to cover more areas within the site. The placement of the $1 \mathrm{~m}^{2}$ units was partially predicated on returns from $50 \mathrm{~cm}$ square shovel tests. The shovel tests were usually placed at $10 \mathrm{~m}$ intervals across the site, usually following the north-south and/or east-west datum lines partially in an effort to gauge the accuracy of the boundaries as defined for the site. The shovel tests were dug in $10 \mathrm{~cm}$ arbitrary leve1s, and 1ocalities showing minimal to heavy artifact returns were enlarged upon.

As noted in Lynn, Fox, and 0'Ma1ley (1977) soil conditions in the reservoir area tend to be extremely clayey. The soils did not lend themselves to easy digging, nor straight profiles. Most units, shovel tests or larger test units, were excavated down to sterile soil, which averaged $70 \mathrm{~cm}$. Sterile was defined as a $25 \mathrm{~cm}$ thick calcium-laden layer which underlies the clayey loam. At two sites 41 MC 63 and 41 MC 84 crews excavated $40 \mathrm{~cm}$ into the caliche layer in an effort to determine if that layer represented a false hiatus in the cultural sequence at the sites. Excavation into the caliche layer was also done at $41 \mathrm{MC} 63$ and 41 MC 186, where there was a $35 \mathrm{~cm}$ interruption in the cultural material within the buried deposits.

Although some natural stratigraphy was apparent in the units, in most cases arbitrary levels were dug. The natural stratigraphy was typically a decrease in gravel size as one dug lower, with a concomitant increase in clay and decrease in rodent activity. Soil color did not vary to any great extent, except becoming slightly darker as clay was encountered.

\section{SITE DESCRIPTIONS}

Each of the sites tested and surface collected by the TAMU crew are described as to their physical characteristics, location, and artifacts recovered. Although an attempt was made to standardize collection and testing procedures from site to site, obviously differences occurred depending upon the topographic and vegetational variables encountered at each locality.

\section{LK 19}

Site 41 LK 19 is located about 200 meters south of the Frio River and 900 meters north of Highway 72 , about $3 \mathrm{~km}$ east of Calliham. The site is situated on the modern floodplain with an oxbow lake forming the northeastern boundary and the Frio River channel delimiting the north and northwest portions of the site. The site is bisected by $a^{-}$former property line designated here as the Johnson (west) and Davidson (east). The Johnson property was not accessible to the survey crew so all work was confined to the Davidson property. 
Previous test excavations consisting of a single $1 \mathrm{~m}^{2}$ unit were conducted by the Texas Historical Commission during the course of their survey of the reservoir basin (Lynn, Fox, and 0'Ma11ey 1977:104-108).

The site area is estimated to be about 30,000 square meters, or some 175 meters north-south and 175 meters east-west. Two dirt ranch roads intersect at the western line of the Davidson property. The east-west oriented road separates the site into two arbitrary horizontal divisions termed "strata." To the south of the road is a cultivated field and an extensive area of dense mesquite, persimmon, slippery elm, and grapevine and assorted thorny brush 7 ies to the north of the road.

Cultural material occurs in the form of isolated scatters of 1ithic and shell debris within the area designated by the site boundaries. These scatters are more evident in the cultivated field because of better ground visibility. Erosional areas in the brush covered portions of the site also reveal traces of cultural refuse.

A baseline was established 12 degrees east of magnetic north and a secondary basel ine was marked 12 degrees south of east (Fig. 6). Grid points were established along these base lines in order for test excavations to be oriented on a grid system.

One test pit was excavated in each of the two designated strata. These are described as follows:

Test 1 (N69.5/E90) was a $2 \mathrm{~m}^{2}$ unit located in Stratum 1 . It was excavated in $10 \mathrm{~cm}$ arbitrary levels. After level 1, the excavation was confined to the southeastern $1 \times 1$ quadrant which was excavated an additional $10 \mathrm{~cm}$. Excavation did not extend below $20 \mathrm{~cm}$ below ground surface. Cultural material was found to be sparse but the greatest concentration was in the southeast corner. Lithic material was not common but mussel and snail shells were noted in the 10-20 cm level. The matrix was a very hard, compact gray clay which appeared homogeneous and was difficult to excavate.

Test 2 (N88/E44) was a $2 \mathrm{~m}^{2}$ unit located in Stratum 2. The area was selected for testing because of the relatively concentrated amount of lithic materials eroding out of the edge of the north-south dirt road. The full unit was excavated to a depth of $20 \mathrm{~cm}$ and the southwestern quadrant was excavated to a depth of $50 \mathrm{~cm}$. The soil was gray-brown slightly friable loamy clay grading to a dense gray-brown loamy clay. Cultural materials, consisting of chipped stone residue, mussel and snail shells and some burned chert, were found to a depth of $40 \mathrm{~cm}$ level.

Exploratory shovel tests were made along the northern and eastern boundaries of the site in an effort to better define the site boundary. These tests yielded no cultural material.

\section{Artifact Discussion}

The artifacts from 41 LK 19 other than shel1 consist of only 2 cores and 140 flakes. The sample is too small to advance anything other than a minimal 


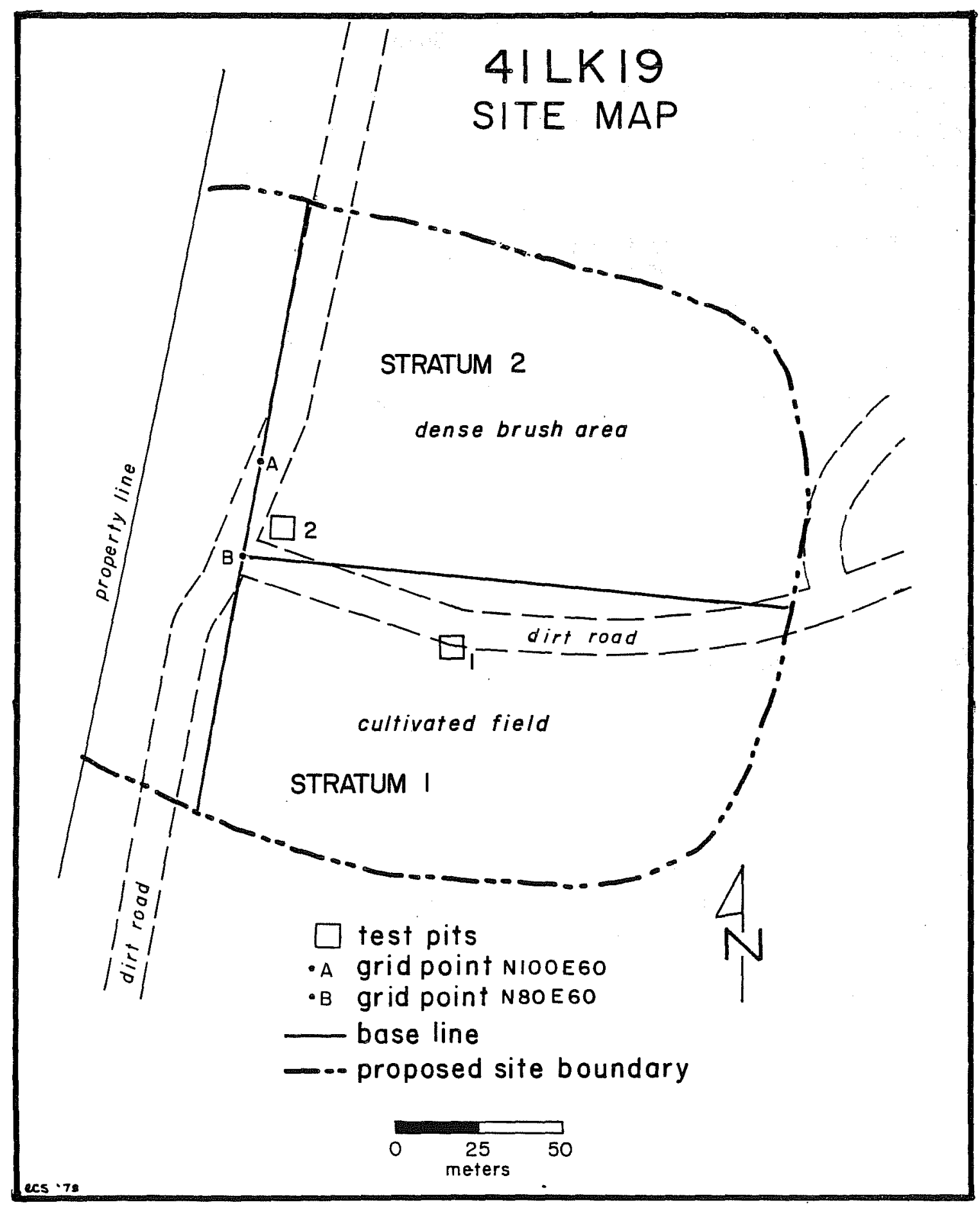

Figure 6. 41 LK 19 Site Map. 
statement regarding site utilization. The presence of cores, flakes, mussel, and snail shell indicates a habitation site of unknown duration and of unknown frequency of use. Its temporal placement also remains obscure.

\section{LK 56}

41 LK 56 is situated $5.44 \mathrm{~km}$ east of FM99 at the junction between the fossil floodplain and the Valley Wall (Lynn, Fox, and 0'Malley 1977:Table 5). The site is a large lithic scatter, $150 \mathrm{~m}$ east-west and $176 \mathrm{~m}$ north-south. It has been disturbed by a ranch road which trends south to north through the western portion of the site. In addition, some clearing was conducted to the northern edge of the site and a deer blind constructed within the cleared area.

The site, which is situated on the slope of a small hill, follows the slope downward. The greatest concentration of material is located on a natural plane which interrupts the gentle rise of the slope. Some erosion is occurring in both the road bed designated as Transect 1 (see Fig。7), and to the western edge of the site.

Vegetation is thicker to the downslope, southern portion of the site, with several large mesquite present. The upper, or central and northern sections are covered with several varieties of grass, scrub oak, and creosote. As the surface collecting was conducted during the late summer, the grasses did not present themselves as a hindrance to either collection or determination of site boundaries.

The site was initially walked and boundaries were flagged when the artifacts reached a density of three or less per square meter. Because of the dense concentration of material in the flat area of the site, a temporary datum was established at the western edge of the flat area of the site and an east-west transect (Transect 3) was established from this point. Another transect (Transect 4) was estab7ished $15 \mathrm{~m}$ to the south. The transect 1 ines were three meters wide, walked by two people, each on one side of the transect corridor. In addition, one north-south transect, again three meters wide, was run from the temporary datum downslope along the road bed to the southern boundary of the site.

\section{Artifact Discussion}

The artifact sample from 41 LK 56 is diverse and indicates extensive use of this site during prehistoric times. Although temporally diagnostic artifacts are rare (namely one Pandora projectile point), we suspect that most of the debris accumulated during the Archaic period. Activities carried out at this site were evidently many and varied as the material remains indicate. Manufacture of stone tools resulted in an impressive array of debitage including cores of every category; primary, secondary, and interior flakes, Stages 1-3 biface failures, and several biface implements. The location of the site in the proximity of good lithic resources may account for the high incidence of debitage. However, we would not classify the site as a lithic procurement locality in view of the number and kinds of implements found here. 


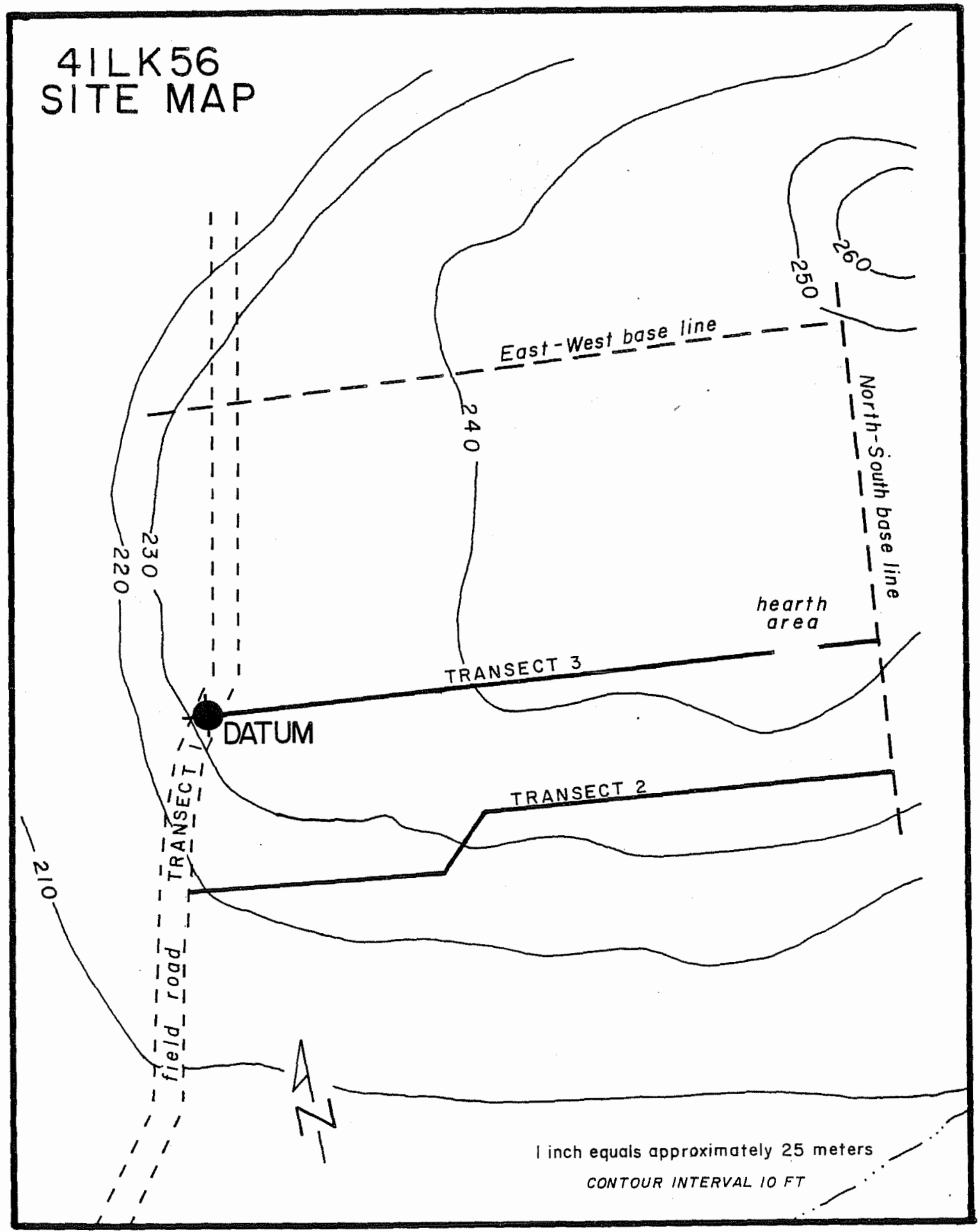

Figure 7. 41 LK 56 Site Map. 
Site 41 LK 90 is located on the north side of Charlie York Hollow on a segment of the fossil floodplain. The site was covered with rather dense vegetation at the time of testing although concentrations of scattered cultural materials could be seen in bare and eroded areas. The site slopes gently from north to south and where vegetation is sparse, erosion is considerable.

A metric grid system was established using triangulation from a north-south base line (Fig. 8). Three $2 \mathrm{~m}^{2}$ units were excavated for the purpose of examining the subsurface structure of the site. Unit 1 (N92/W105) was found to be in an area of severe sheet wash and was excavated to a depth of only $10 \mathrm{~cm}$. Although a relatively good sample of cultural material was recovered from the unit, refuse was confined to the surface. The subsurface soil was a gray clay, extremely hard and essentially devoid of cultural material.

Unit 2 (N20/W49.5) was excavated to a depth of $30 \mathrm{~cm}$. Very little cultural material of any kind was recovered from Unit 2. Traces of 1 and and aquatic shell and a few flakes constitute the bulk of the cultural remains.

Unit 3 (N30/W25) was placed immediately west of a concentration of shell and burned rock exposed on the surface. The unit was excavated to a depth of $10 \mathrm{~cm}$, exposing the shel1 and burned rock concentration over the entire unit. Charcoal, along with what appeared to be a burned area, possibly a hearth, was identified in the shel1 lens.

The testing of 41 LK 90 indicated the presence of scattered concentrations of cultural refuse, some lithic, some mostiy of shell, shallowiy buried along the fossil floodplain. The surface has been subjected to moderate to severe erosion that has displaced much of the cultural deposit.

\section{Artifact Discussion}

The inventory of artifactual material recovered from 41 LK 90 is small. Most lithic refuse other than burned rock is the product of flintknapping activities. Two implements, a Tortugas point and a Nueces scraper provide the only means of establishing a temporal context. The material dates within the Archaic period.

\section{MC 60}

Situated on the northern edge of the floodpool boundary, the site is located to the middle section of the George Jambers property, approximately $6.88 \mathrm{~km}$ north of the confluence of E7m Creek and the Frio River. 41 MC 60 is located to the east and south and at the foot of Opossum Hill, which appears to be composed primarily of layered gravels. Two large cuts, in the western and eastern slopes of the hill, expose a stratigraphy that shows at least two hiatuses, or flood deposition layers. Most of the chipped material recovered from the site appear to come from these gravel sections. 
Figure 8. 41 LK 90 Site Map.

PAGE 38 REDACTED 
Although two farm roads occurred along the eastern and southern boundaries of the site, it has not been disturbed in the center where the largest amount of material was concentrated. However, the vegetation is extremely thick across the site, composed primarily of hackberry, low mesquite, scrub oak, and several other brush varieties and this hindered the establishment of collection units or transect lines.

The site is basically subrectangular in form, with the long axis trending genera11y north-south some 185 meters. The east-west width is approximately 142 meters and 41 MC 60 blends into the northeastern corner of 41 MC 61 . Because of the vegetational cover we utilized the top of the survey vehicle as a staging platform and ran three-meter wide transect corridors off a temporary datum located at the extreme eastern edge of the site. Each corridor became the spoke of a fully extended fan: Transect 1 ran 90 meters at a 45 degree angle west of north from the datum, Transect 2 extending 120 meters west from datum and Transect 3 running 85 meters 45 degrees west of south from datum. Areas between the spokes were walked, but not collected.

The concentration of material appeared along Transect 2, with Transect 1 yielding little except for large cobbles and Transect 3 revealing only isolated clusters of debitage. So, while the site is extensive in area, the concentration of material is in the central portion of the locality.

\section{Artifact Discussion}

The artifacts recovered from 4] MC 60, like many of the Choke Canyon sites, is dominated by debitage from flintknapping activities. A11 core categories, secondary and tertiary flakes, and Stages 1-4 biface failures are all well represented in the sample. Implements consist of three projectile points and two biface tools. The projectile points, a triangular specimen, a side-notched example and a Dare, suggest utilization of this site during the Middle and Late Archaic times.

\section{$41 \mathrm{MC} 61$}

The western side of Opossum Hill slopes moderately down to Elm Creek. This colluvial slope is littered with cultural debris and is eroded by a series of southwest draining gully tributaries of Elm Creek. The gently sloping areas between these gullies, while part of the same physiographic feature, have been designated as separate archaeological sites. 41 MC 60, the largest and easternmost of these sites, has already been described. Site 41 MC 61 is bordered by two gullies, the one to the east separates it from 41 MC 60 while the one to the west forms the divide between it and 41 MC 62 .

The cultural deposit at 41 MC 61 was reported to be a surface scatter disturbed by erosion. Work carried out included a thorough surface inspection and collecting a small, uncontrolled sample of artifacts. 


\section{Artifact Discussion}

The artifact sample recovered from 41 MC 61 was meager and consisted of a core, flake, and miscellaneous chipping debris. It is not possible to ascertain a date range for the activities that were carried out here. It is also not possible to recognize specific cultural activities from the sample collected.

\section{MC 62}

$41 \mathrm{MC} 62$ is situated to the west-northwest of $41 \mathrm{MC} 60$, approximately $6.24 \mathrm{~km}$ north of the confluence of Elm Creek and the Frio River. Cut along its western and southern edges by ranch roads, the site has extensive gully action to the north. It is located on the valley wall outwash, close to lithic source materials eroding from the large gravel hill to the north (Fig. 9).

According to the property owner, George Jambers, the site locality has been plowed and cleared to allow for pasturage. Only remnant natural vegetational stands are present on the eastern edge of the site, and are composed of predominately creosote, hackberry, and mesquite. Tall grasses cover the site.

Actual site boundaries were never determined at the northern and western edges because of erosional problems. Several transects were walked across the area and determined the primary occupational area is approximately 65 meters eastwest and 103 meters north-south. Because of the hindering grass a general surface collection was made and artifact concentrations were flagged during the collection process.

Two $1 \mathrm{~m}^{2}$ units were laid out adjacent to separate artifact concentrations. The first yielded no artifactual material to a depth of $60 \mathrm{~cm}$. It showed an undifferentiated profile composed of a hard-packed clayey loam, gray to gray-black in color. Little gravel was noted in the matrix, and no shells nor snails were recovered.

Test Unit 2 was situated 20 meters northwest of Unit 1 and again yielded no artifactual material. It was excavated down to a depth of $55 \mathrm{~cm}$, and, as with Unit 1, was composed of extremely hard-packed clayey loam. Two $50 \mathrm{~cm}^{2}$ test units were randomly placed to the north-east and north of Unit 2 and again showed geological composition identical to Units 1 and 2. They, 1 ikewise, yielded no artifactual material.

\section{Artifact Discussion}

Like the sample from 41 MC 61, the collection from 41 MC 62 consists entirely of lithic debris (2 cores, primary, secondary and tertiary flakes, and miscellaneous chipping debris). Because of the absence of implements and temporally diagnostic items, we cannot make functional and temporal assessments regarding the prehistoric activities at this site. 


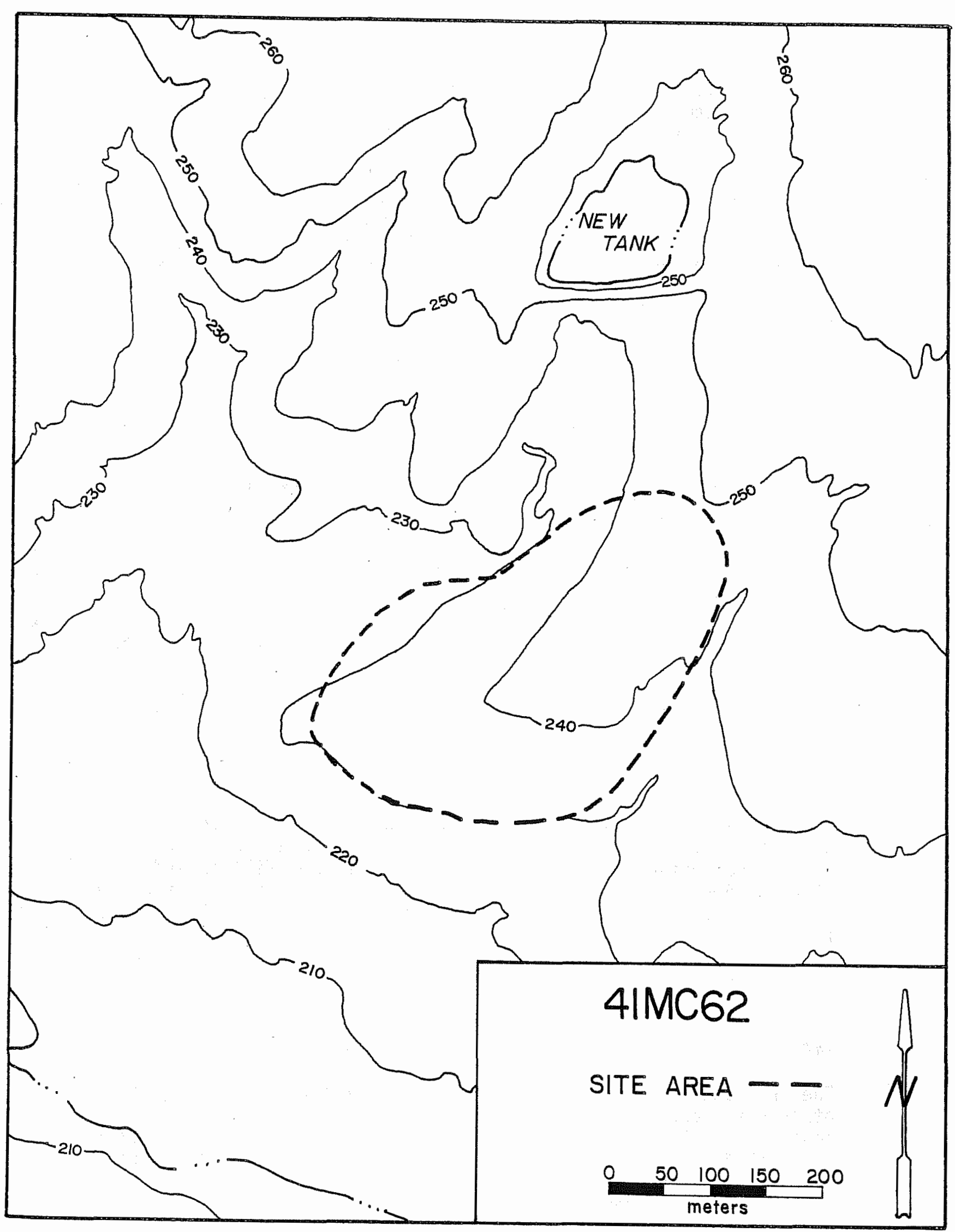

Figure 9. 41 MC 62 Site Map. 
41 MC 63

Site 41 MC 63 is located on the north side of the Frio River a short distance upstream from the mouth of Elm Creek. The site is on the fossil floodplain and covers an area of about 175 meters east-west and 40 meters north-south (Figs. 10, 11).

An east-west grid base line was established for the purpose of making a controlled surface collection and excavating a series of $50 \mathrm{~cm}^{2}$ test pits spaced approximately 10 meters apart. These pits were excavated to evaluate the subsurface structure of the site. The location, depth, and artifacts from each test pit are listed below:

$\begin{array}{lll}\begin{array}{l}\text { Grid Location } \\ \text { N20/E28 }\end{array} & \begin{array}{l}\text { Depth } \\ 0-62 \mathrm{~cm}\end{array} & \begin{array}{l}\text { Observations } \\ \text { she11, flakes, burned } \\ \text { rock }\end{array} \\ \text { N10.4/E32.7 } & 0-60 \mathrm{~cm} & \begin{array}{l}\text { flakes } \\ \text { she11, flakes } \\ \text { N20/E10 }\end{array} \\ \text { N10/E0 } & 0-70 \mathrm{~cm} & \begin{array}{l}\text { she11, fläkes, burned } \\ \text { rock, mano }\end{array} \\ \text { N41/E1 } & 0-45 \mathrm{~cm} & \text { flakes } \\ \text { N20/E40 } & 0-30 \mathrm{~cm} & \begin{array}{l}\text { she11, flakes, burned } \\ \text { rock }\end{array} \\ \text { N20/E700 } & 0-40 \mathrm{~cm} & \text { trace of material } \\ \text { N20/E10 } & 0-53 \mathrm{~cm} & \begin{array}{l}\text { she11, flakes, burned } \\ \text { rock }\end{array}\end{array}$

Field observations noted two levels of cultural refuse concentration in the test pit profiles. The soil matrix is a sandy clay loam varying from light $\tan$ at the surface to a gray-tan charcoal-stained fill extending at least to a depth of 50-70 cm. While some cultural material (namely flakes) was encountered throughout the fill down to the sterile subsoil of a yellow-tan mottled clay, the density of material was relatively high in the upper $20 \mathrm{~cm}$. A similar situation was observed at 41 MC 186 which is located nearby and on the same alluvial formation.

\section{Artifact Discussion}

The artifact sample observed from 41 MC 63 was relatively large compared to other sites and the site is prolific in terms of cultural refuse. While a controlled collection was made in an effort to secure a good sample of cultural material for study, most of this collection was not available for analysis. However, field notes describe finding several biface failures and a Perdiz arrow point. The sample that was not analyzed consists only of flaking debitage 
Figure 10. 41 MC 63 Site Map.

PAGE 43 REDACTED 


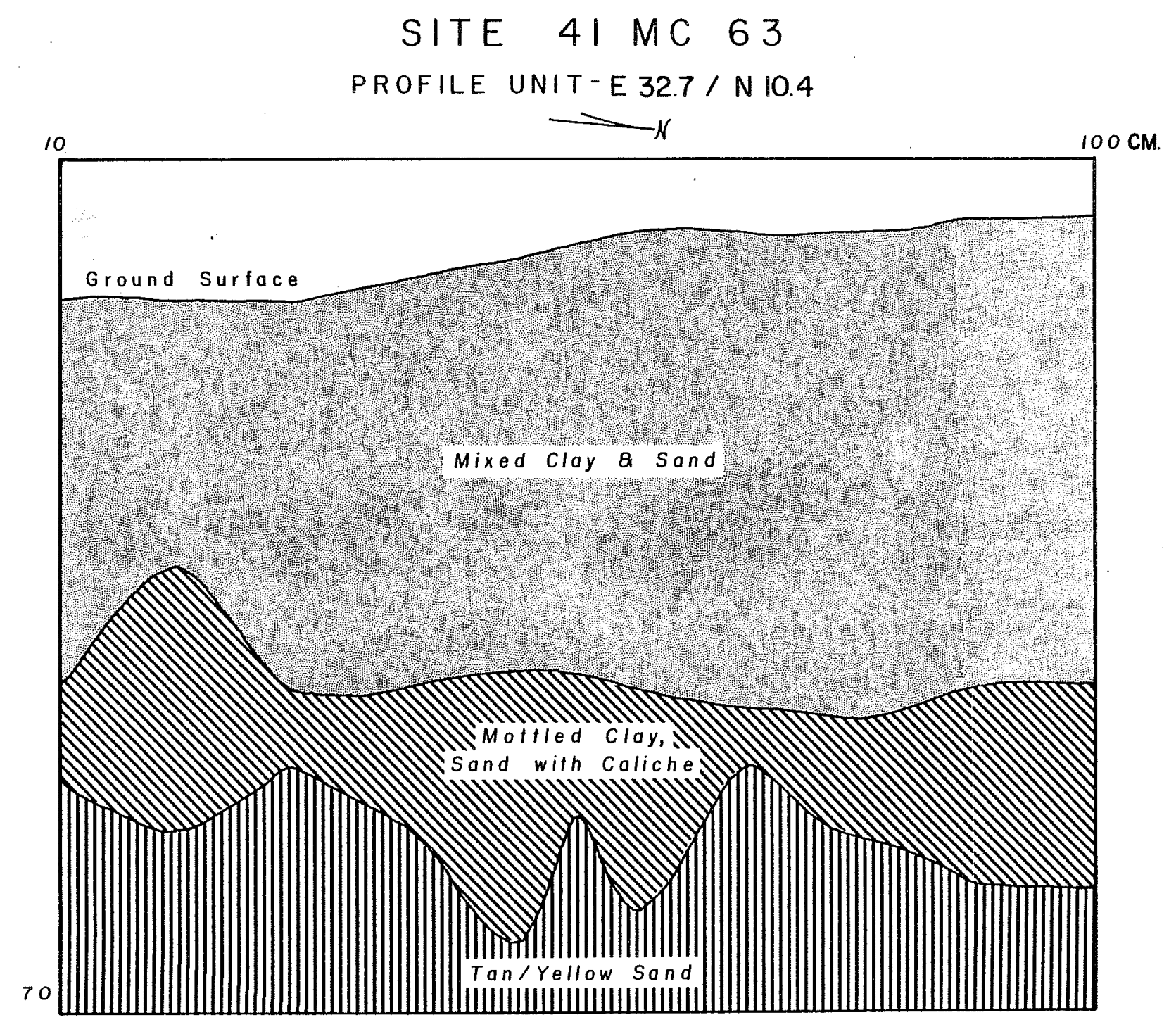

Figure 11. Profile of 41 MC 63. 
thus making functional assessments difficult. Site 41 MC 63 is a stratified cultural resource that bears further investigation. It dates certainly in the Late Prehistoric period and may contain earlier materials as well.

\section{$\underline{41 \text { MC } 70}$}

$41 \mathrm{MC} 70$ is located to the western edge of the test locality approximately $14.40 \mathrm{~km}$ east-northeast of Tilden along an unnamed farm road. It is 400 meters north of the Frio River on the first terrace above the river, but partially overlying onto a remnant finger of the fossil floodplain. Of the nine surfacecollected sites, it is the most disturbed with the main farm road trending west to east through the northern portion and the central and southern portions plowed and disturbed by farm building construction.

The site, as defined prior to surface collection, is an extremely long, narrow oval. The maximum width is 65 meters and the east-west length is 214 meters. Areas where the vegetation has not been cleared are concentrated to the western end of the site, and are composed of tall mesquite trees, grasses, and several large hackberry stands. Because of the extremely disturbed nature of the site, no formal collection strategy was employed. The field locality, which composed approximately 70 percent of the area of the site, was selected as the primary area for concentration of effort.

The crew dispersed across the site in a "scrimmage 1 ine" formation and collected any material identified during the survey. Individuals were no more than two meters apart. Concentrations of material were flagged for inclusion in the sketch map of the site. However, no more than 15 items were identified in any one concentration.

\section{Artifact Discussion}

The artifact sample from 41 MC 70, like most of the Choke Canyon sites, is entirely of chipped stone. The diagnostic materials include single examples of Abasolo, Tortugas, and Pandora dart points and a hint of a Middle Archaic lithic scatter. The cultural activities carried out at this locality were quite numerous and varied; biface tool production is clearly in evidence as refuse. from all stages of biface reduction are in the collection. Also, cores, primary, secondary and tertiary flakes are well represented.

\section{MC 87}

Site $41 \mathrm{MC} 87$ is situated about $13.60 \mathrm{~km}$ north-northeast of Tilden just to the north of the Frio River. It is one of several sites which border the river on the north and form an almost continuous occupational zone for several kilometers in that area. The site has been cleared of brush and plowed revealing a soil matrix which indicates the site rests upon the modern floodplain. Only remnant stands of original vegetation are now present in the site vicinity, principally along the southern edge. 
The site (Fig. 12) is large, elliptical in configuration, with the long axis trending east-west some 326 meters. The site's maximum width is 156 meters. A primary datum was established at the western edge, 78 meters south of the northern boundary which is the unnamed farm road. The datum is a 16-inch long metal stake which was marked with a metal tag bearing the site designation followed by the letters "TAMU 77." It represents the NO/EO point on a grid which was lain out over the site after the determination of the site boundaries.

Only quadrant corner stakes were shot in, using Brunton and stadia 1ine. Each quadrant was subdivided into $2 \mathrm{~m}^{2}$ collection units and a random 33 percent of each of the units were collected. If the initial collection units proved fruitless, a second grouping was drawn. As opposed to other sites surface collected or tested, 41 MC 87 showed a patchy distribution pattern in terms of the artifacts. Concentrations were noted with flagging attached to long wooden stakes driven into the ground. These were plotted on the base map and one concentration was chosen for a $2 \mathrm{~m}^{2}$ test unit. Seven other refuse areas were also chosed for $50 \mathrm{~cm}^{2}$ test pits.

The seven test pits, designated T.P. 1-7, yielded little in the way of geological information indicating primarily that a sterile extremely hard-packed; gray-brown clay layer began between $45 \mathrm{~cm}$ and $70 \mathrm{~cm}$ below present ground surface.

While Test Unit 1 revealed no features, it did show a constant though small number of flakes down through level $4(30-40 \mathrm{~cm}$ below surface). After that until $70 \mathrm{~cm}$ below present ground surface only isolated flakes appeared usually in association with rodent burrows. All fill, from test pits and the test unit, was screened using 1/4-inch heavy duty mesh screen. The soil in al1 the units was a clayey loam extremely hard-packed, and crumbly. Little in the way of mussel shells or snails was noted.

\section{Artifact Discussion}

The artifact sample from 41 MC 87 indicates a multi-component, multi-activity site. Diagnostic artifacts include projectile point types Ensor, Desmuke, and a single-notched arrow point, indicating predominately a Late Archaic and Late Prehistoric utilization. Other implements include a biface tool fragment, grinding slab, and biface cobble choppers. Cores are not common in the sample but reduction debitage in the form of biface failures (all stages), primary, secondary, and tertiary flakes are all well represented.

\section{MC 173}

The site is located $7.52 \mathrm{~km}$ south-southeast of the confluence of the Frio River and $E 7 \mathrm{~m}$ Creek at the extreme southern edge of the Morrill Ranch. It has been cut along its western and southern edges by a ranch road, and the site proper is located in a plowed field, which at the time of collection was partially pasturage and partially sorghum field. The site is situated on the modern floodplain and has, as have sites 41 MC 180, 41 MC 187, 41 MC 188, 41 MC 184, $41 \mathrm{MC} 183,41 \mathrm{MC}$ 181, and $41 \mathrm{MC} 63$, been subjected to periodic inundation by the Frio River. 
Figure 12. 41 MC 87 Site Map.

PAGE 47 REDACTED 
The site measures some 100 meters north-south and 92 meters maximum, east-west. It is basically ovoid in shape with the locality of greatest width occurring at the northern end of the site.

The sampling strategy was initially to be collection transects; however, because of the ground cover which impaired viewing, the site was divided into eight sections of equal area and four were chosen for detailed examination. Because of an extremely low artifact return, two more areas were selected, adding little to the sample size.

\section{Artifact Discussion}

The artifact sample from 41 MC 173 is sma11, consisting only of debitage. Primary, secondary, and tertiary flakes and miscellaneous chipping debris constitute the collection. Because of this fact, little can be said about the temporal span or function of the site.

\section{MC 180}

$41 \mathrm{MC} 180$ is situated just to the east of the Frio River approximately $4.96 \mathrm{~km}$ southeast of the confluence of Elm Creek and the river. The site, as such, was never defined and in all probability became included in the initial reconnajssance of 41 MC 183 and 41 MC 181 which are adjacent to the site. As initially recorded by Lynn, Fox, and 0'Malley (1977) it was only 40-60 m in diameter and separated from 41 MC 183 by a small erosional cut. Resurvey of the locality could not separate, nor define, an entity from the adjacent sites.

Although the site locality was grass-covered, the cover was sporadic and a clear view of the ground was possible. Utilizing the available maps, we essentially backtracked from 41 MC 185, which was a historic house foundation and therefore more definite in its placement than some of the lithic scatters. The presumed locale of the site was carefully examined, and while no definite boundaries could be determined and arbitrarily defined, a $50 \mathrm{~m}^{2}$ unit was flagged and all material, of which there was very little, was collected. It should be noted that prior to testing 41 MC 181 its boundaries were marked and they included 41 MC 180 which during the initial six-week excavation and collection phase was not a site under consideration by TAMU.

\section{MC 181}

Site 41 MC 181 is located on a Pleistocene terrace ridge east of the Frio River and about 300 meters southeast of 41 MC 183. The site is bisected by a northeastsouthwest transecting fence line which crosses the ridge crest at right angles. This fence was used as the basic field reference line for locating two sma71 $50 \mathrm{~cm}^{2}$ test pits which were excavated to examine the subsurface nature of the site.

Unit 1 was located 12 meters north of the fence on the crest of the Pleistocene terrace ridge. The pit was excavated to a depth of $45 \mathrm{~cm}$ and cultural refuse was not seen below $25 \mathrm{~cm}$. The soil is a light tan leached sand. Unit 2 was 
located on the western slope of the ridge 10 meters north of the fence line. This test pit was dug to a depth of $43 \mathrm{~cm}$ through a tan, leached sandy soil. The cultural material, consisting mainly of flakes debitage, was not found below $35 \mathrm{~cm}$.

\section{Artifact Discussion}

The artifact sample recovered from 41 MC 181 is sma 11 , consisting mainly of flake debitage and a single Stage 2 biface failure. A triangular, plano-convex biface and a lunate-shaped biface constitute the only implements recovered. Unfortunately, no information was recovered which would allow for accurate temporal or functional assessments to be made.

41 MC 183

41 MC 183 is situated approximately $5.92 \mathrm{~km}$ south-southeast of the confluence of the Frio River and Elm Creek, south and east of the locality for 47 MC 180. Figure 13 shows 47 MC 183 as a small site, basically teardrop in plan. The site is situated on the modern floodplain at the southern end of the Morrill Ranch.

The site is within a sorghum and pasturage field, and the locale appears to have been under cultivation for several years. The site boundaries were remarkably we11-defined given the cultivation and ground cover at the time of the survey.

After the site boundaries had been defined a grid system was superimposed over the area by establishing a zero datum point in the approximate center of the site and selecting 22 units of $50 \mathrm{~cm}^{2}$ size, drawn randomly within the combined four quadrants of the grid for shovel testing. These test pits, shown in Figure 14, were excavated to sterile yellow clay. The findings of each of the test pits is summarized below:

\begin{tabular}{|c|c|c|c|c|}
\hline Grid Location & Soil & Depth of Test & Artifacts & Comments \\
\hline N135/WO & black clay & $30 \mathrm{~cm}$ & $\begin{array}{l}\text { burned rock, } \\
\text { debitage }\end{array}$ & $\begin{array}{l}\text { Artifacts } \\
\text { from } 0-15 \mathrm{~cm}\end{array}$ \\
\hline N15/W0 & brown sandy loam & $70 \mathrm{~cm}$ & $\begin{array}{l}\text { debitage, } 1 \\
\text { glass fragment }\end{array}$ & \\
\hline N75/W0 & brown sandy loam & $50 \mathrm{~cm}$ & $\begin{array}{l}\text { burned rock, } \\
\text { debitage } \\
\text { snail shel1 }\end{array}$ & $\begin{array}{l}\text { Artifacts } \\
\text { from } 30-50 \mathrm{~cm}\end{array}$ \\
\hline No/E45 & brown sandy loam & $50 \mathrm{~cm}$ & debitage & $\begin{array}{l}\text { Artifacts } \\
\text { from } 10-30 \mathrm{~cm}\end{array}$ \\
\hline S52/W90 & dark brown clay & $50 \mathrm{~cm}$ & $\begin{array}{l}\text { debitage, } \\
\text { snail she11, } \\
\text { burned rock }\end{array}$ & \\
\hline
\end{tabular}


Figure 13. 41 MC 183 Site Map.

PAGE 50 REDACTED 


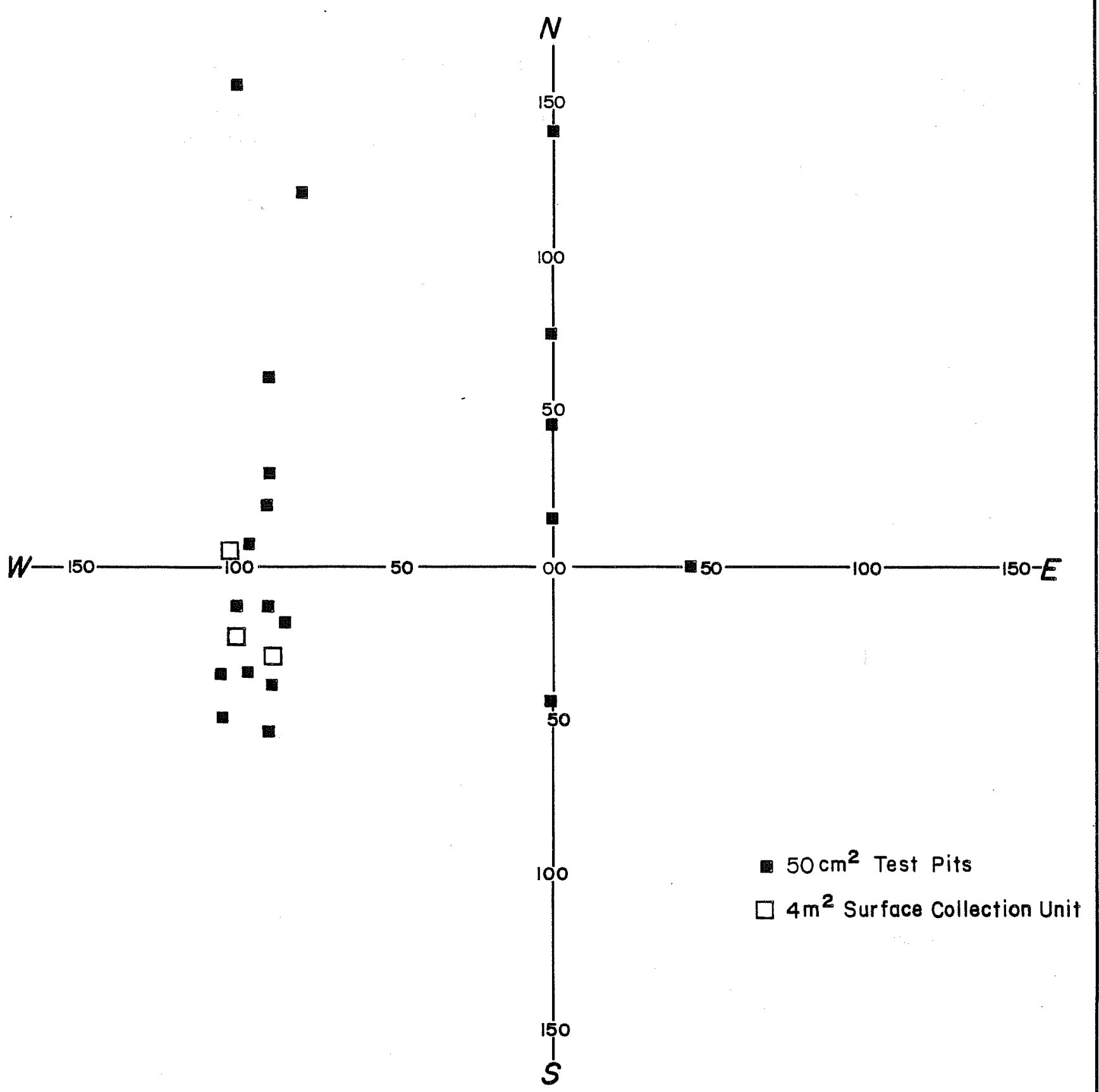

SITE 4 IMCI83

LOCATION OF TEST PITS

Figure 14. Site 41 MC 183, Location of Test pits. 


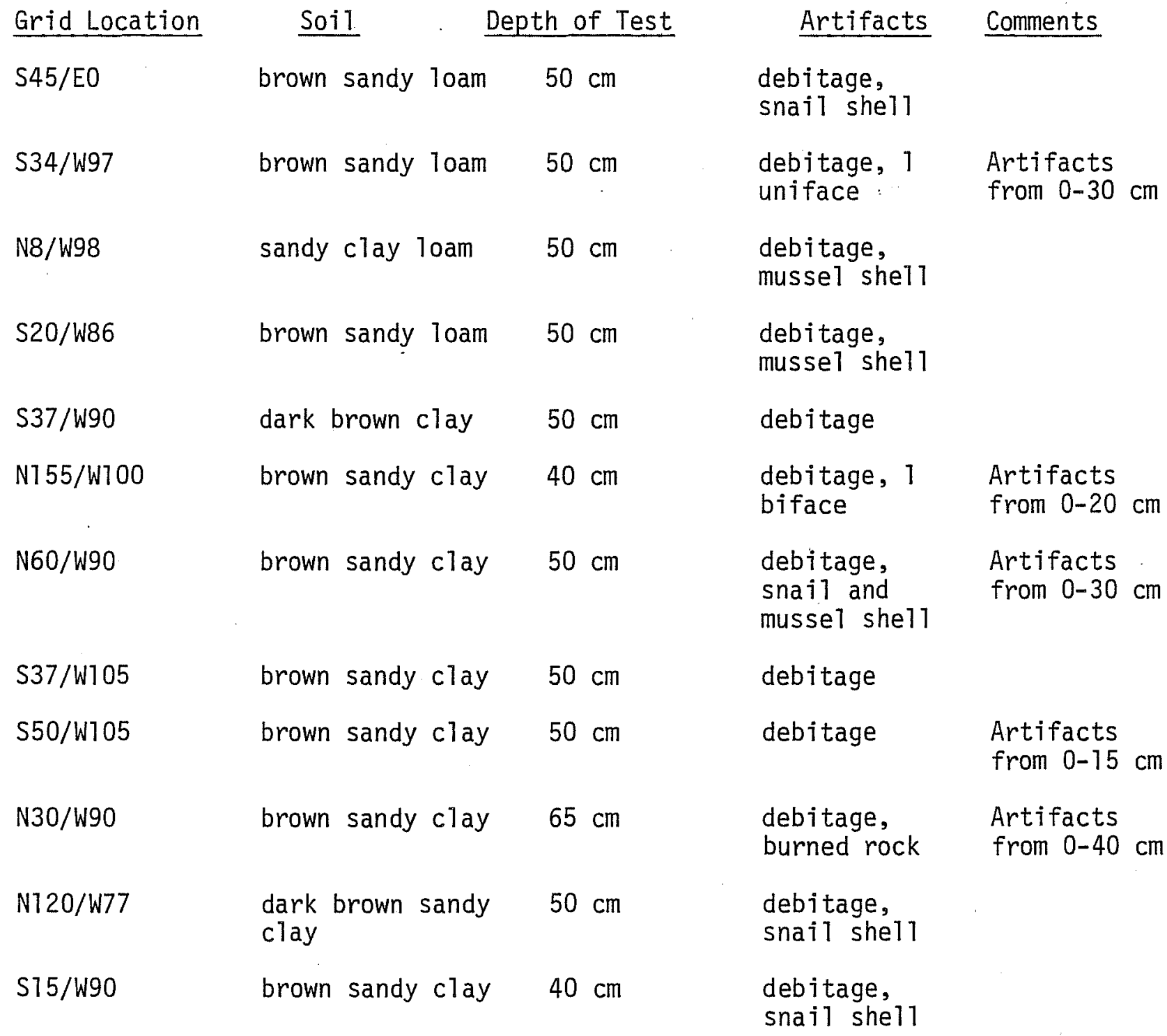

In addition to these test pits, three $4 \mathrm{~m}^{2}$ surface collection units were established from grid points S22/W100, S26/W86 and N8/W700. The intended purpose of these surface collection units was to randomize the surface sample. However, the overall sample was too small for statistical manipulation and was treated analytically as a single surface collection.

\section{Artifact Discussion}

The artifacts recovered from 41 MC 183 indicate that this locality witnessed a diversity of cultural activities during the Middle and Late Archaic periods. Dart point types Catán, Ensor. Bulverde, and Pandora and miscellaneous triangular forms and miscellaneous contracting-stem forms are used as the basis for the chronological placement. Functional tools other than projectile points are not common. 
Debitage is abundant at this site and include all core categories, all aborted biface categories, flakes (primary, secondary, and tertiary), and other chipping debris.

41 MC 184

41 MC 184 is situated on the west side of a small knoll approximately $4.00 \mathrm{~km}$ east of the confluence of Elm Creek and the Frio River. This site completely surrounds 41 MC 185, a historic house foundation. This knoll is at the northern edge of a flat portion of the modern floodplain, which contains 41 MC 173, 41 MC 174, 41 MC 180, 41 MC 181, and 41 MC 183. Geologically 41 MC 184 is a finger remnant of the fossil floodplain which pits into the modern floodplain. The site is covered with chert cobbles which are eroding out of the gravel layers that underlie the present ground surface.

The configuration at the site is virtually round, its north-south length being 120 meters and its east-west length 125 meters. The site was viewed as a circle and divided into eight sections, all radiating from a mid-point within the circle. Four were fully collected, the remainder walked, artifact concentrations marked and noted on the site map.

Because of the amount of unmodified material present on the surface, cobbles in all probability had been broken by cattle, vehicle traffic or through some other means; therefore, any material which did not show bulb, platform, or percussion marking was only occasionally picked up during the collection.

\section{Artifact Discussion}

The artifact sample from 41 MC 184 is very similar in terms of implements and diagnostic items to that recovered from $41 \mathrm{MC} 186$. The site was utilized during the Middle and Late Archaic periods as evidenced by the occurrence of Catân, Ensor, and Pandora dart point types. The presence of mussel shells, burned rocks, and other tools such as a biface tool fragment and a biface cobble chopper hint of varied campsite activities. The debitage sample recovered include aborted bifaces, primary, secondary and tertiary flakes, and other chipping waste.

\section{MC 186}

Site 41 MC 186 (Fig. 15) is located on an outside bend north of the Frio River immediately downstream from the mouth of Elm Creek. The site covers a large area measuring some 800 meters east-west and 300 meters north-south of the fossil floodplain. The internal structure of this site is very similar to 41 MC 63 and, for a11 intents and purposes, may be a continuation of that site. Most of the site was in cultivation at the time of the TAMU investigation but mesquite savannah with intermixed thorny brush covered the portion of the site not in cultivation.

Grid base 1 ines, one oriented 14 degrees east of north intersected by another at right angles to the north-south line, were established. Fifteen $50 \mathrm{~cm}^{2}$ test pits were excavated at random points over the main site area to examine the 
Figure 14. 41 MC 186 Site Map

PAGE 54 REDACTED 
internal structure. The test pits varied in depth from 45 to $90 \mathrm{~cm}$. A $2 \mathrm{~m}^{2}$ unit was also excavated to check the volume of artifactual material.

The subsurface tests revealed a hard-packed, sandy clay soil on the surface which ranged in color from gray, gray-brown to tan. Beneath this topsoil was a zone of homogeneous gray-tan soil to a depth of about $70 \mathrm{~cm}$ where it graded into a tan sandy clay.

Cultural material appears on the surface and within the first $20 \mathrm{~cm}$; from 20-60 cm, very little cultural material was found. Another concentration of cultural material was encountered between $60-90 \mathrm{~cm}$ in some units. The findings in the $2 \mathrm{~m}^{2}$ unit confirmed the pattern observed in the smaller tests. Although the amount of cultural material was modest, an opportunity to gain a good, essentially unweathered sample seems promising at this site.

The possibility that 41 MC 186 is a stratified site should be explored. The general feeling among the field personnel was that two possibilities existed for the seemingly stratified nature of the fill: (1) the stratigraphy actually reflects a temporally separate occupational horizon; (2) the upper or surface material was reworked and redeposited by erosion and was equal in age to the deeper deposit. The artifact sample, discussed below, did not shed any light on the stratigraphic problem.

\section{Artifact Discussion}

Only one implement was recovered in the testing of $41 \mathrm{MC} 186$. This was a triangular biface tool, probably a gouge or adze. The remainder of the lithic material consists of flaking debitage and burned rock. Cores are notably absent but primary, secondary, and tertiary flakes are especially well represented. Only two aborted bifaces were recovered. The absence of diagnostic cultural material makes functional and temporal assessments impossible.

\section{MC 187}

Situated to the north of 41 MC 186, 41 MC 187 forms the medial section of a continuous line of cultural resources which lie just to the east and north of the $\mathrm{Elm}$ Creek-Frio River confluence. The two sites are only differentiated from one another by intermittent gullying. 47 MC 187 has been badly eroded along its western flank, and the central and eastern portions have been disturbed by farm road construction and plowing, respectively.

The site lies on the modern floodplain. The remnant original vegetation is restricted to riparian tree communities along the western edge of the site and rather dense scrub oak and hackberry immediately on the terrace rise above the immediate floodplain of. Elm Creek.

The boundaries to the site were tenuous at best. To the south only a gully separated 41 MC 187 from 41 MC 186, and to the north again only a gully separated 
it from 41 MC 188. The western edge, where the densest artifact return was identified, was badly eroded. Only to the east could a good approximation be made. The site was approximately 87 meters east-west and 133 meters north-south. The site was vaguely D-shaped, with the western edge representing the straight leg of the letter.

The site was completely gridded, as was 41 MC 186 and 41 MC 188. The primary datum at 41 MC 186 was utilized to anchor all three grid systems, in case anyone ever decided to treat the sites as one. However, it should be emphasized that the secondary datums established at 41 MC 187 and 41 MC 188 can function independently of each other and 41 MC 186. The site was gridded into $4 \mathrm{~m}^{2}$ units and a 25 percent sample was collected.

Two $1 \mathrm{~m}^{2}$ test units were established along the western edge of the site. Both Units 1 and 2 were only $43 \mathrm{~cm}$ deep before sterile, hard-packed, gray clayey loam was encountered. Neither yielded more than five artifacts each. Nine $50 \mathrm{~cm}$ shovel tests were randomly placed, again yielding little in the way of artifactual material and reaching a maximum depth of $52 \mathrm{~cm}$ (Shovel Unit 7 ). The upper $10 \mathrm{~cm}$ were a loosely consolidated sandy matrix sharply demarcated from the underlying consolidated gray-brown clay-sand layers. Several narrow cultural lenses of mussel shell, or snail clusters were noted at erratic intervals in the various units, concentrated between $23-41 \mathrm{~cm}$ below surface.

The artifact sample retained from the work at 41 MC 187 numbers only three specimens; all are items of debitage and preclude functional and temporal assessments.

41 MC 188

41 MC 188 is situated immediately north of 41 MC 187, approximately $2.08 \mathrm{~km}$ north-northwest of the confluence of Elm Creek and the Frio River. 41 MC 188 is the least disturbed of the trio, showing some gullying on the southern portion of the site and plowing in the eastern section of the locality. The site is situated on the modern floodplain, and is predominately covered with short grasses and mesquite, the latter confined to the southern and western edges of the site where it slopes down into the immediate Elm Creek floodplain.

The site is somewhat amorphous in shape with the maximum north-south length 145 meters and the maximum east-west width 87 meters. It was gridded into $2 \mathrm{~m}^{2}$ units, and a 25 percent sample was selected for collection. Two $2 \mathrm{~m}^{2}$ units were selected for excavation, one downslope along the southern edge of the site, the other (Test Unit 2) upslope from Unit 1 on the flat of the site. Maximum depth achieved in Unit 1 was $110 \mathrm{~cm}$, al1 artifactual material was concentrated in the first $45 \mathrm{~cm}$ below surface.

Test Unit 2 was taken down to a depth of $40 \mathrm{~cm}$, then halved and taken down another $30 \mathrm{~cm}$. As at $47 \mathrm{MC} 187$, both mussel she11 and snail clusters cultural in origin appeared erratically in narrow lenses beginning at about $24 \mathrm{~cm}$ below present ground surface and extending to $45 \mathrm{~cm}$. No geological lensing was noted, with exception of the initial differentiation between the sandy upper $13 \mathrm{~cm}$ of the stratigraphy and the underlying consistent gray-brown clayey loam. While occasional flakes appeared in this clayey loam, and anywhere from $70-115 \mathrm{~cm}$ 
below the surface, an extremely hard-packed clay, light gray to light orange in color then appears. This was consistently sterile.

The artifact sample from 41 MC 188 consists solely of debitage in the form of aborted bifaces, primary, tertiary flakes, and other chipping debris. Temporally and functionally diagnostic artifacts are absent.

\section{LITHIC TECHNOLOGY}

The lithic artifact samples constitute the largest class of archaeological data from the TAMU survey. An attempt is made here to recover information from the collection which can be used to provide: (1) a better understanding of the technology and use of the lithic resources; and (2) how this technology was integrated in the adaptive strategies of the prehistoric populations.

Although we feel obligated to go beyond a descriptive treatment of the sample, it is necessary to provide descriptions of the assorted categories of chipped stone artifacts. These categories are based on our observations of combinations of attributes; as observations they constitute the first level of anthropological inquiry on which all subsequent interpretaions and generalizations are based. In order for the reasoning and validity of the interpretative statements to be communicated, it is essential that the data from which these generalizations are made be described and, where possible, illustrated.

In an effort to go beyond the purely descriptive treatment, it is essential to frame the lithic study in a way that the analytical procedures are oriented toward providing a set of observations that can be used to deduce patterns of human behavior.

The sorting of the Choke Canyon lithic sample was directed at understanding the choices exercised in the procurement, reduction and use of the lithic resources. The sorting began by separating implements from debitage (Bradley 1975) and further sorting the debitage following a lithic reduction model: [ithic reduction models are not uncommon in the archaeological literature le.g., Mallouf, Fox, and Briggs 1973; Shafer 1973; Fox, et al. 1974; Hester 1975; Bradley 1975; Collins 1975; Patterson 1977; Lynn, Fox, and 0'Malley 1977) and are designed as analytical tools to assist the archaeologists in estab= lishing a functional/behavioral context for the lithic materials.

This idealistic approach to lithic analysis is immediately wrought with problems with the Choke Canyon sample. Given the poor context of each collection (i.e., all are essentially surface collections) there is virtually no time control available. Secondly, the functional range of activities in which stone tools were incorporated is unknown; while certain activities can be inferred (such as repair of hunting weapons on the basis of broken projectile points; use of adzes, etc.,) we are left to rely only on those tools which have been either manufactured to fit some preconcejved form (such as projectile points) or which have been reduced through patterned use and retouch resulting in a patterned shape as with gouges, Nueces scrapers, etc. Implements which have been structured for immediate and one-time use and then discarded (and which in reality probably constitute the largest class of tools) are beyond 
the range of identification. This statement, while open to criticism, is an admission of the limitations posed to the analyst working with surface samples, particularly a surface sample that has been exposed probably since the time of deposit. Flake or core tools meant for single, short-term utilization usually lack formal design and limited wear patterns which make their identification often very difficult. Analysis by Shafer and Holloway (1979) of implements in this class recovered from a dry cave context point out the sober reality that surface samples from open sites such as we have for Choke Canyon pose the greatest limitation for functional studies. Furthermore, the problem of identifying short term or single use implements made on sharp-edged blanks is further complicated by the chances of post-depositional alterations of the flake edges. For this reason we are hesitant to classify all edge-damaged flakes as implements based on an inspection of 50 randomly chosen flakes from the Choke Canyon collections. Microscopic analysis revealed some form of edge damage on all 50 samples and the nature of much of this damage falls into the ranges of that usually considered man-made. We seriously doubt that the incidence of tools was that high.

RAW MATERIAL

Raw materials for the manufacture of chipped stone tools are common in the Choke Canyon area. A summary of the geology and distribution of lithic resources has been provided by Lynn, Fox, and O'Malley (1977). Chert and quartz gravels and silicified wood nodules are abundant along the valley walls and in the stream channels (ibid.:18). Nodules of chalcedony also occur locally as do a variety of sandstones usable for coarse chipped, abrading, and ground stone artifacts.

The cherts, which are general7y of poor quality, are apparently derived from the reworked Uvalde Gravels (Sellards, Adkins, and Plummer 1958:778) and the Cretaceous Edwards Plateau outcrops. The gravel deposits at Choke Canyon are nearing the mature stage as the softer material such as limestone transported from upstream has all but disappeared while cherts occur in the form of we11rounded cobbles and pebbles. The silicified woods occur in more immediate geological deposits (Lynn, Fox, and 0'Malley 1977) and, while the cortex displays noticeable weathering, they are usually elongated subangular nodules. With few exceptions the cortex on the cherts is characteristically battered from transport, displaying innumerable: percussion impact scars and often distinct Hertizian cones. The naturally induced alterations had a significant effect on the chipping quality of the material.

The rounded nature of the chert cobbles posed particular problems to the aboriginal flintknappers and several techniques of reduction have been described by Lynn, Fox, and 0'Malley (1977:100-103). The solution of reducing rounded cobbles was not always easily solved due to the inability at times to establish a suitable striking platform. One interesting technique of rendering these resources usable for biface and sharp edge flake production was to split the cobble using a direct impact blow (Crabtree 1972:41; Hester 1975). This peculiar technique resulted in producing. a split bulb of force and marked concentric rings suggesting that the cores were subjected to a severe compressive 
force, similar to bipolar technique but without evidence of the rebound stress. The bulbar portions of the flakes are sheared resulting in a condition similar to that illustrated by Crabtree (1972:91).

\section{ARTIFACT DESCRIPTIONS}

Brief verbal descriptions are given for each group of artifacts in order to convey both a general idea of form and to point out distinctive characteristics such as fracture or wear patterns not necessarily evident on illustrated examples. Efforts are made to keep these descriptions short and concise. The provenience and metric data for all implements are presented in Table 3; examples of most descriptive categories are illustrated in Figures 16-20.

The initial sorting was set up to follow a functional paradigm separating debitage (flakes, cores, assumed failures in the course of biface production) from those artifacts assumed to be tools. The tools were then sorted on the basis of technology (uniface and biface) and were further subdivided on the basis of more specific attributes.

\section{Biface Implements}

Artifacts classed in this category are interpreted as being implements based on form, edge wear, and technology. While the presumed working edge on certain of these tools may be formed by unifacial retouch, biface technology was used to shape the original blank.

Triangular, Plano-Convex Implements (2 specimens: Fig. 16, A,B)

Both of these objects have wide, steeply beveled distal ends; they taper toward a narrow proximal end which is broken by a roll-snap fracture on one example and is convex on the second. Both specimens exhibit an almost identical wear pattern; the distal edges exhibit light smoothing and polish. The polish extends to the ventral surface along the edge. The polish is very fine and no striations could be seen under 40X magnification.

\section{Biface Tool Fragments (4 specimens; Fig. 16,C-E)}

These items are proximal ends to either adzes or gouges. Their lateral edges uniformly exhibit dulling and smoothing but no polish. The distal ends are all broken or badly damaged; one is broken by a roll-snap fracture and two appear to be damaged by use, retouch or shattering. A11 are apparently portions of once hafted tools; this assumption is based on the characteristic dulling of the lateral edges presumably to aid in securing a haft.

Triangular Biface Tool (1 specimen; Fig. 16,F)

This is a plano-convex triangular biface. The wider end is beveled but no evidence of wear can be seen. While this specimen is classed as an implement on the basis of form and technology, it may be a preform for a gouge or an adze. 
TABLE 3. IMPLEMENTS: PROVENIENCE AND METRIC DATA.

Class Biface Tools

Triangular, Plano-Convex

Biface Tool Fragment

Triangular Biface Tool

Nueces Scrapers

Rectangular Biface

Lunate-Shaped Biface

Biface Cobble Choppers

Abasolo

Catân

Dare

Ensor

Desmuke

Tortugas

Miscellaneous Triangular

Miscellaneous SideNotched

\section{Provenience}

41 MC $60 / 6$

41 MC $181 / 0$

41 LK 56/T2E

41 MC $87 / 0-1$

41 MC $183 / 33$

41 MC $184 / 5$

41 MC $186 / 21$

41 MC $60 / 1$

41 MC $90 / 13$

41 MC $183 / 18$

41 MC $181 / 0$

41 LK $56 / T 1$

41 MC $87 / 30$

47 MC $87 / 35$

41 MC $184 / 12$

41 MC $70 / T-3$

46

41 MC $183 / 22$

41 MC $184 / T-3$

41 MC 69/0-1

41. MC $87 / 44 \quad 38 \quad 21$

41 MC $183 / 0-16$

41 MC $184 / 0-4$

41 MC $87 / 0-1$

41 LK $90 / 2$

$41 \mathrm{MC}: 70 / \mathrm{T}-2$

41 LK 56/1-3

41 MC $60 / 5$

41 MC $783 / 7$

41 MC $183 / 16$

47 MC $60 / 0-2$

41 MC $60 / 0-4$
26

47

42

$34 *$

49

46

56

76

71

42

30

26

78

$45^{*}$

23

24

42

19

37

28

34

30

36

28

38

$52^{*}$

27

29
Thickness Weight

22

14

61.0

35.8

51.8

41.2

38.2

51.3

59.7

24.3

10.0

13.2

53.7
9.0

8.3

8.1

4.8

4.7

8.7

3.6

5.9

9.5

9.2

13.8

11.0

8.9

21.5

*measurement for partial specimen 
TABLE 3. (continued)

Class Biface Tools

Provenience Length Width Thickness Weight

Miscellaneous Contracting

Stem

41 MC $183 / 7$

46

26

29

6

7.0

41 MC $183 / 16$

52

29

8

8.8

Basal Notched

41 MC $183 / 16$

29

18

8

5.7

Single Notched

41 MC $87 / 28$

60

36

4

1.7

Bulverde

41 MC $183 / 16$

8

14.1

pandora

41 LK 56/T1

45

41 MC $70 /$ T4

41 MC $183 / 16$

41 MC $184 / T 2$

41 MC 184/6

78

30

25

27

30

27

8
7
9
10
8

10.6

9.5

19.2

7.6

10.3

Triface

41 MC $56 / T 3$

Hammers tone

41 LK 56/T1

Grinding Slab

41 MC $87 / 37$

Nueces Scrapers (2 specimens; Fig. 16,G)

These two tools are bifacially shaped flakes exhibiting one broad, unifacially beveled end. Lateral edges on both are lightly smoothed; the beveled end (distal end) on the smaller specimen is the result of extensive retouch and the edge shows damage by the removal of many small hinge fractures from both sides near the center. A trace of smoothing can be seen along the edge on the ventral surface. The second specimen has been burned but also bears a trace of smoothing and polish along the distal edge. Although function is uncertain, we follow the Nueces scraper definition previously published by Hester, White, and White (1969).

Rectangular Biface (1 specimen; Fig. 16,H)

This interesting specimen is a small rectangular biface of silicified wood that possesses a single, steeply unifacial retouched edge. The beveled edge is the presumed distal edge; smoothing can be detected along the beveled edge along with a trace of polish; smoothing also occurs along the opposite edge as well.

Lunate-Shaped Biface (1 specimen; Fig. 16,I)

This specimen is a bifacially shaped artifact exhibiting one straight unifacially beveled edge. Light smoothing can be detected along this edge but polish is absent, perhaps due to the fact that the specimen is deeply patinated. 


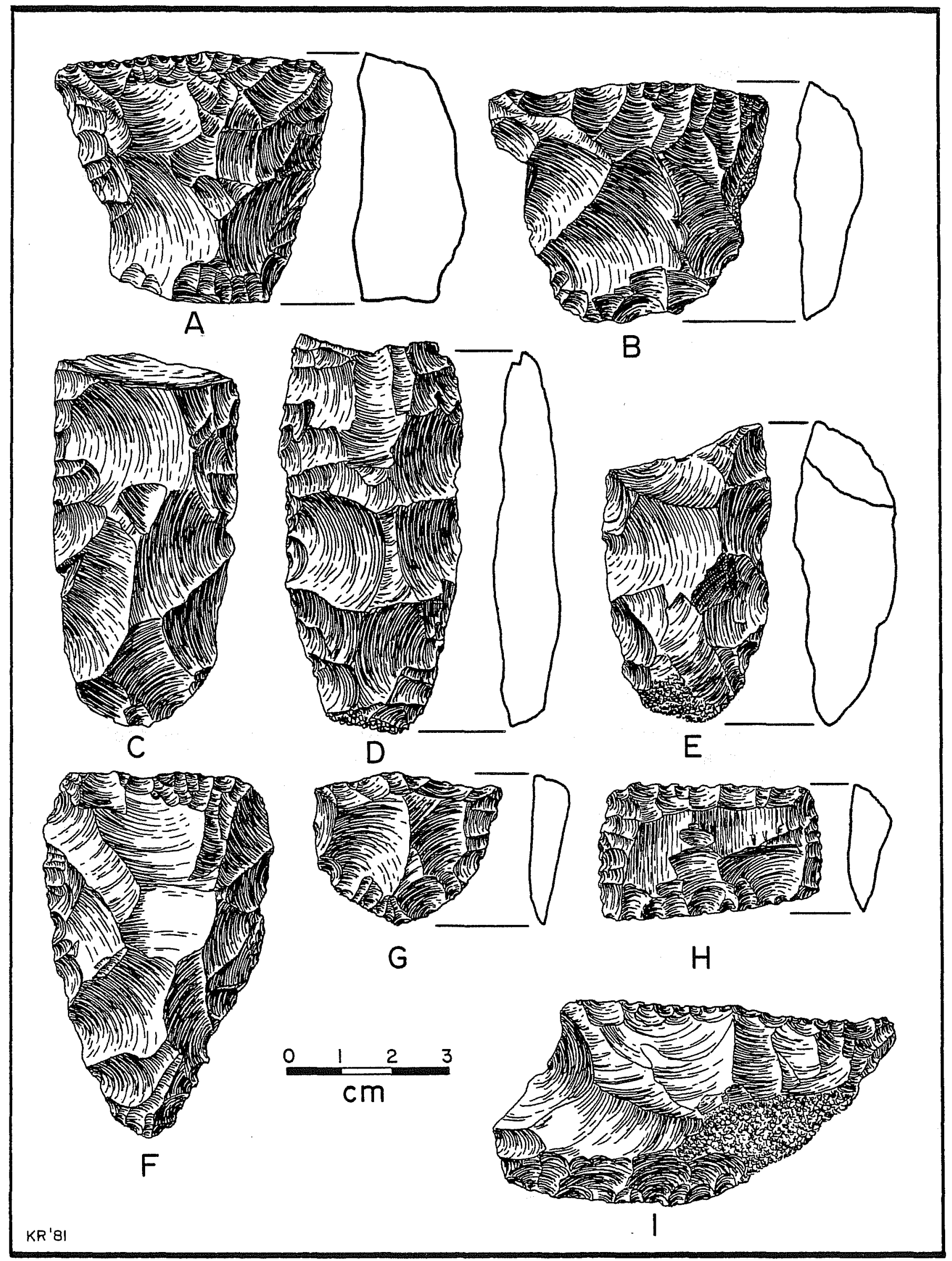

Figure 16. Biface Implements. A, B, triangular, plano-convex implements; C-E, biface tool fragments; F, triangular biface tool; G, Nueces scraper; $H$, rectangular 
Biface Cobble Choppers (3 specimens)

A11 of these artifacts possess one bifacially chipped edge. Two are cobbles retaining mostly cortex surfaces and the third is a recycled core. They are separated from the cores because of the evidence of battering along the bifacial edge. The battering is not extensive on any of the specimens.

\section{Bipolar Pieces (3 specimens)}

Each of these items exhibits evidence of bipolar impact (Shafer 1973:107-114). One is a small spall exhibiting a ridge of percussion (Binford and Quimby 1963) formed by direct impact against rigid material that resulted in numerous stepped and hinge fractures. This edge, viewed from the top, is slightly concave and most of the stepped fractures occur on the concave surface. This item compares closely to MacDonald's (1969:88) pièce écailles and the White's (1968:660) outil écailles. A second specimen is a much larger fragment of a split cobble and is plano-convex in cross-section. One edge is formed by the intersection of the flake facet with a cortex surface and battering is extensive along this edge; the battering resulted during the removal of numerous stepped or hinge fractures from the flatter face and creating what Binford and Quimby (1963) refer to as an area of percussion. The opposite edge exhibits bifacial battering and moderate edge crushing, again from direct impact blows. The artifact appears to have been used as a wedge-like tool. The third specimen is a chert pebble exhibiting one damaged edge from direct impact blows; the opposite edge and end is flat and no evidence of percussor marks can be seen.

\section{Projectile Points (18 specimens)}

The small sample of projectile points was sorted on the basis of form using the Handbook of Texas Archeology: Type Descriptions (Suhm and Jelks 1962) as a guide in identifying the formal types. The validity of these types is open to debate in instances where certain types such as Bulverde, Darl, etc., are on the periphery of their area of common distribution. We chose to follow the type concept to facilitate communication and to provide convenient reference to certain diagnostic forms that may have chronological significance. We did this at the risk of perpetrating the use of possible invalid assumptions regarding the type status and functional connotations of certain bifaces.

Chronologies of projectile point styles have been worked out in the southwest (Johnson 1967) and central Texas (Johnson, Suhm, and Tunnel1 1962; Sorrow, Shafer, and Ross 1967; Wesolowsky, Hester, and Brown 1976) and occasionally variations of the prevalent forms in these areas appear in the coastal plain sites. The potential of cross-dating on the basis of point styles would seem to be promising for Choke Canyon materials. The dominant projectile point (or assumed projectile point) forms are the lanceolate, leaf-shaped and triangular styles, all of which display a 7 imited range of diagnostic attributes compared to the stemmed central and southwest Texas forms. In short, the specimens we sorted into types were done so in hopes that data useful for cross-dating might be preserved. 
The use of diagnostic projectile point forms as temporal indicators on surface sites, particularly the large areas of deflated surfaces common in the choke Canyon area, is one avenue, sometimes the only one, available to date many sites. The archaeologist should exercise a degree of caution, however, and not rely too heavily on the validity of such dates. The lack of buried accumulations of cultural material in the Choke Canyon area, the semiarid nature of the environment and the frequent exposure of ground surface due to erosion and plant dessication have exposed the lithic scatters to human eyes and hands almost since the day they began to accumulate. The possibility that chipped stone artifacts were collected by aborigines for either resource material or to be directly incorporated into their technological repertoire must also be considered. Mixing of materials spanning several centuries is predicted for most of the shallow, mostly surface accumulations further complicating the problem of dating sites.

We must eventually approach the problem of function regarding projectile points. By classing these artifacts under the rubric of "projectile points" commits us to the assumption that they served that function. In truth, we can feel secure only in about 50 percent of the cases. The best indicator of projectile point function is the presence of an impact fracture either on the distal end, base, or both. Few specimens display these features. The next best criterion (although a less secure one) is formal design such as careful thinning, notching, and stemming. This further increases our number of probable known but leaves 68 percent of our sample being composed of unstemmed, thinned, and generally well made bifaces. The assumption that many of these unstemmed forms served as projectile points is founded mainly on circumstantial evidence. The sheer numbers with which they occur in south central Texas, their formal design size and occasional presence of impact fractures, all serve as adequate evidence of their function. The problems one encounters in working with a sample such as this is that latter stage lanceolate and triangular preforms are very difficult to separate from defined type categories such as Pandora, Kinney, and Abasolo. Furthermore, one could justifiably question the validity of the Abasolo-Desmuke separation or the Catan-Desmuke separation due to the overlap in variation. The Abasolo and perhaps certain specimens classed as Pandora may even be a preform to the Catan-Desmuke forms. What we wish to stress is that when these types were set up in the 1950s the concept of biface manufacture following a reduction sequence and the occurrence of failures in the sequence was not fully realized nor anticipated in the classification scheme. Consequentiy, what one classes as a latter stage preform or a lanceolate projectile point is purely arbitrary and based on the kind of subjective feeling that dominated Krieger's (1944) criteria for initially sorting artifacts into tentative types. In Krieger's system, used widely throughout Texas, anything that was not regarded as a projectile point was dismissed from typological consideration. So we are left with a classification system that is dated and serves only specific ends. It can be legitimately argued that to continue to employ such a system hampers substantive research. However, we have stated the reason for referring to the type of system in this report regardless of its shortcomings.

\section{Abasolo (1 specimen; Fig. 17,A)}

The specimen exhibits a convex base and slightly asymmetrical blade. Flaking appears to be mostly by percussion with little or no pressure trimming. 


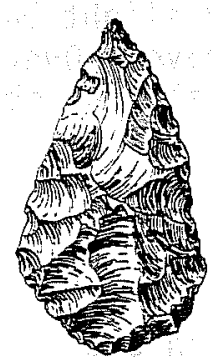

A

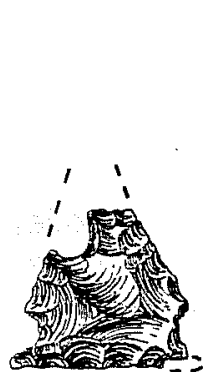

G
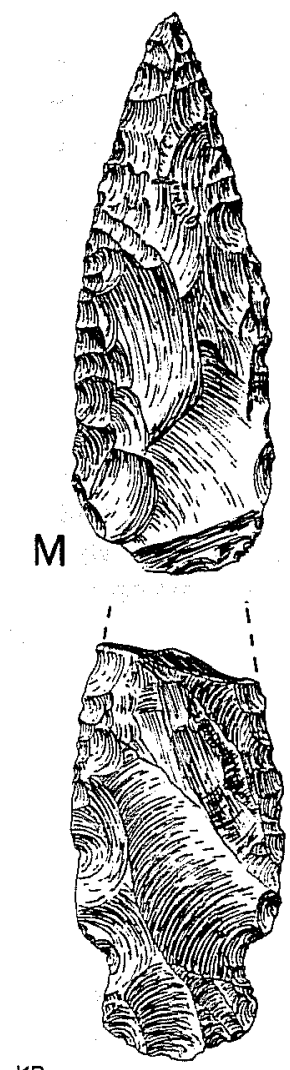

$\underset{\mathrm{BI}}{\mathrm{K}} \mathrm{R}$

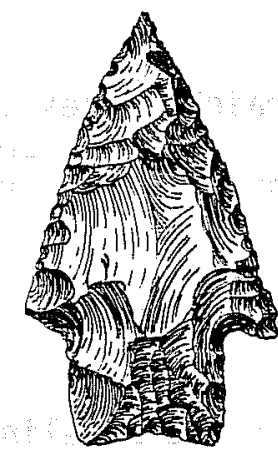

B

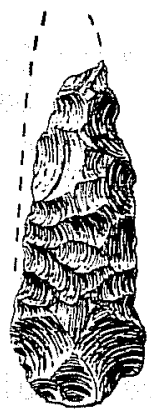

C

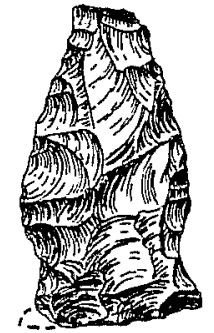

$\mathrm{H}$

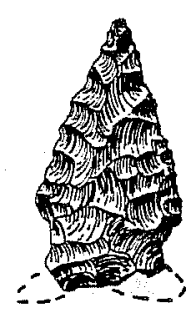

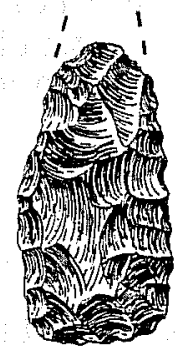

D

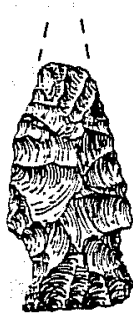

$E$

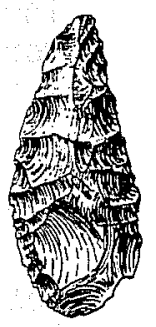

$\mathrm{F}$
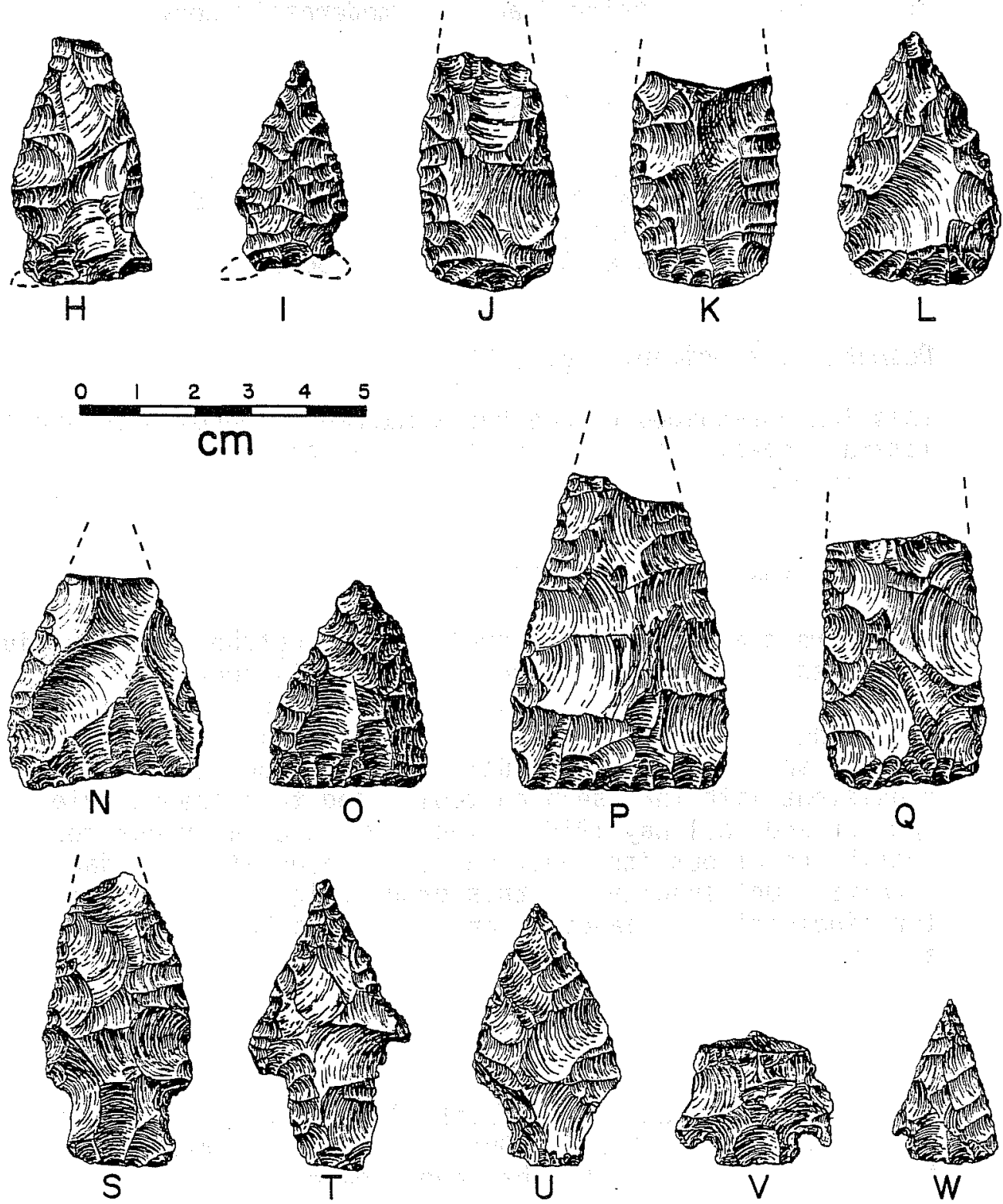

Figure 17. Projectile Points. A, Abasolo; B, Bulverde; C, D, Catän; E, Darl; F, Desmuke; G-I, Ensor; J-M, Pandora; N, O, Tortugas; P, Q, miscellaneous triangular; $R, S$, untyped side-notched; $T, U$, contracting stem; $V$, basa 7 notched; $W$, single notched. 
Bulverde (1 specimen; Fig. 17, B)

The blade is triangular with approximately straight edges and slight barbs. The stem is faintly contracting and the base is slightly concave. Overall workmanship is good and the material is a light gray-tan translucent moderately patinated flint.

Catân (2 specimens; Fig. 17, C,D)

Both specimens have alternately beveled blades; the beveling on one is to the left and to the right on the second example. Both exhibit direct impact fractures. Bases are thinned and are moderately convex.

Dare (1 specimen; Fig. 17,E)

Sma11, expanding stem biface with a straight base. Shoulders are moderate and blade is narrow with straight lateral edges. Specimen appears to have been reworked after suffering an impact fracture. Lateral edges exhibit pressure retouch which forms a slight bifacial bevel.

Desmuke (1 specimen; Fig. 17,F)

This lozenge-shaped biface has a markedly convex base and slightly convex lateral edges. It is alternately beveled to the left on both faces by pressure retouch.

Ensor ( 3 specimens; Fig. 17,G-I)

These are characterized by shallow side notches near the juncture with the base. The bases on two are straight and slightly convex on the third. One specimen (Fig. $17, \mathrm{H}$ ) has evidently been recycled and used as a slicing tool since smoothing and extensive polish occurs on one edge and surface. This smoothed and polished edge has been unifacially retouched. The nature of the wear is consistent with that seen on tools used to slice succulent plant material (Shafer and Holloway 1979). The form is clearly one resembling an Ensar projectile point but its function, or perhaps its secondary function, was that of a knife. One specimen in this group ( $F i g . ~ 17, G$ ) exhibits a severe impact fracture indicating a glancing contact with a hard surface. All Ensor specimens are pressure retouched.

Pandora (5 specimens; Fig. 17,J-M)

These are lanceolate points with slightly concave lateral edges, rounded basal corners and convex bases. One specimen was broken by an impact fracture while the distal end of another has been reworked. 
Tortugas (2 specimens; Fig. $17, N, 0$ )

Both of these specimens are triangular in outline. One (Fig. 17,0) is basally thinned and is alternately beveled along the right edge of both faces. This specimen was also reworked at the distal end. The second specimen is better thinned but does not exhibit beveled edges.

Miscellaneous Triangular (4 specimens; Fig. $17, P, Q$ )

Each of these have straight bases, squared or slightly rounded basal corners and straight lateral edges. A11 are well thinned lateral edges and are trimmed by pressure retouch. The bases are similar to Pandora but are straight instead of being convex; likewise for the same reason they differ from the indented base Kinney.

Untyped Side-Notched (2 specimens; Fig. 17,R,S)

Both of these specimens have expanding stems; one exhibits a bulbar stem with rounded basal corners and a markedly convex base. The second has a straight base. Lateral edges on both are mildly convex.

Contracting Stem (2 specimens; Fig. $17, T, U$ )

These two artifacts have contracting stems and triangular blades with prominent shoulders. One specimen is manufactured from a well thinned distal end of a biface. The base is formed by the break and shows thinning efforts. The stem is formed by alternate unifacial chipping which created beveling along the left side of both faces. The specimen may appear to be a Nolan but the similarities in the stem attributes are, we believe, fortuitous. The second specimen has a straight base and weakly beveled shoulders. Both exhibit pressure thinning and pressure retouch.

Basal Notched (1 specimen; Fig. 17,V)

This very poorly made stem fragment has a short, wide stem formed by two shallow basal notches. The blade has small barbs and the lateral edges are sinuous. The flake scars exhibit curious patterning in that compression rings are common in facets on both surfaces.

Single Notched (1 specimen; Fig. 17,W)

This expertly made small arrow point exhibits a single corner notch on the edge of an otherwise triangular preform. The material is translucent silicified wood. The base and lateral edges are straight. 
Uniface Toots

Tools classified under this heading exhibit one or more edges formed by unifacial retouch or trimming. Retouch is defined as deliberate flaking struck to prepare an edge such as in beveling whereas trimming is the unifacial alteration of an edge formed by either pressure flaking using an instrument or by pressing the flake against a rigid surface and pressing off a continuous series of tiny flakes along the edge.

\section{Pointed Uniface (1 specimen; Fig. 18,A)}

This specimen is a secondary cortex flake that has been unifacially retouched to a tapered point. Minute edge grinding can be seen near the top along the left lateral edge.

Unifacially Retouched Flake (1 specimen; Fig. 18,B)

This artifact is a cortex flake produced when a cobble was split by a direct impact blow. One edge exhibits steep beveling produced by retouch. Steep, small hinge flakes were removed from the center of the edge; the ventral surface exhibits a trace of polish along the edge near the center.

Cobble Uniface (1 specimen)

A plano-convex chert cobble possesses one wide, coarse unifacially retouched end. A trace of polish could be seen near the edge on the ventral face but this may be the result of stream abrasion rather than wear.

Uniface with Tip (1 specimen; Fig. 18,C)

This is a secondary cortex flake possessing a carefully chipped tip (possibly used as a graver) formed by unifacial chipping. The top is slightly smoothed and rounded presumabiy from use.

Miscellaneous Unifaces (5 specimens; Fig. 18,D,E)

One (Fig. 18,E) is a secondary cortex flake with retouched distal edges; the edge is denticulate and shows no evidence of use. A second specimen (Fig. 18,D) is also a cortex flake with one sinuous unifacially retouched edge. The opposite edge exhibits evidence of numerous direct impact blows creating an area of percussion (Binford and Quimby 1963). There is no evidence of wear seen in the microscopic examination.

Another miscellaneous uniface is a fragment. The unifacially trimmed edge exhibits some smoothing but due to heavy patination, no polish can be detected. A crescent-shaped thermal spall from a plano-convex tool represents another 


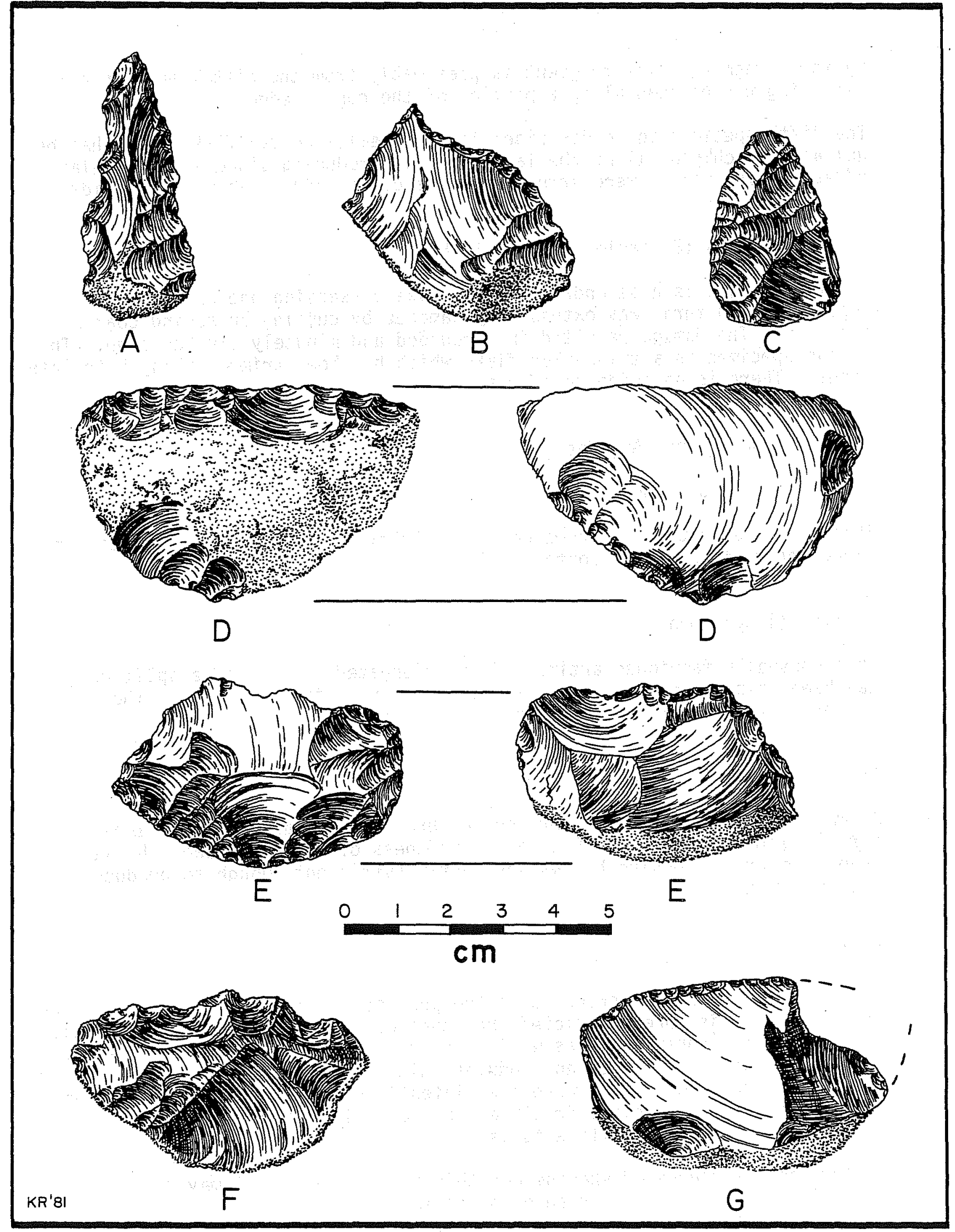

Figure 18. Uniface Tools. A, pointed uniface; B, unifacially retouched flake; $C$, uniface with tip; D, E, miscellaneous unifaces; F, G, utilized flakes. 
uniface fragment. The fragment is presumably from the distal end since moderate smoothing can be seen along a portion of the convex edge.

The fifth specimen to be described is an annealed cortex flake which has been unifacially chipped along the lateral edges producing sinuous, denticulate edges. These flakes were struck from the cortex side. No wear is evident.

Utilized Flakes (2 specimens; Fig. 18,F,G)

One (Fig. 18,F) is a secondary cortex flake possessing one unifacially trimmed edge which, in turn, was extensively damaged by cutting or sawing coarse material. The damage resulted in a rounded and minutely crushed edge. The second specimen is a triangular flake which has been trimmed along both lateral edges. There is no evidence of wear.

\section{Miscellaneous Lithic Artifacts}

Hammerstone (1 specimen)

This is a fragment of a burned chert cobble exhibiting noticeable battering along one portion of the cortex surface.

\section{Triface (1 specimen)}

This unusually fashioned artifact is an elongated section of a split cobble that has been chipped on three faces as well as across the wider end. The narrower end exhibits possible dulling along a portion of the edge.

\section{Grinding Slab (1 specimen)}

A smal1, soft sandstone slab broken in three pieces has one flat, apparently abraded grinding surface. Due to the sofitness of the sandstone, the wear could have been very extensive but was evidently sufficient enough to produce a noticeable facet.

\section{Debitage}

Debitage is the residue produced in the purposeful reduction of lithic resources. The definition is more restricted than that of Crabtree (1972:58) who includes the remains of broken tools as we11. The debitage is sorted into cores, flakes, and biface failures. Cores and nodules which exhbit one or more flake removals and flakes are pieces which have been intentionally removed from a core and bear evidence of conchoidal fracture. Biface failures represent unsuccessful attempts to manufacture biface tools.

Failure in the course of shaping and thinning a biface tool may result from several factors including crushing or collapsing of the striking platform; premature hinge or snap fractures (cf. Crabtree 1972) of thinning flakes that 
result in the inability of the knapper to remove a thick portion; end shock where the vibrations of a specific blow cause the biface to exceed the material's elasticity and snap; overshot or outrepasse and perverse fractures which occur in the course of thinning; and material flaws. The skill of the knapper and the quality and nature of the raw material are other factors that affect the frequency of failure.

The provenience and metric data for biface failures and cores are presented in Table 4. The measurements for the biface failures include length, width, thickness, and weight. The cores are measured only across the maximum dimension.

\section{Biface Failures}

The biface debitage is sorted into four stages based on the relative degree of reduction, thinning, and shaping. This concept of sorting biface debitage was first suggested for the Choke Canyon 1ithics by Shafer (1976) and the sorting here follows closely that of Patterson (1977).

Stage 1 (28 specimens; Fig. 19,A-C)

These artifacts represent the initial step in the bifacial thinning of thick flakes or cobbles. Failures resulted in the inability to adequately shape or thin the chosen blank as indicated by unsuitable platforms, hinge fractures, collapsed platforms or material flaws. Most of the blanks chosen for reduction are thick flakes produced by splitting rounded flint cobbles; three are flat oval cobbles (one of silicified wood) which have been initially bifaced. One is a recycled patinated flake. The shapes vary considerably from oval to roughly rounded. One characteristic of this group is that no definite form had been achieved.

Stage 2 (24 specimens; Fig. 19,D-F)

The reduction of these examples was carried further than those of Stage 1 in that steps were taken to begin to thin or shape the bifaces. These specimens compare closely technologically to Patterson's (1977:40) Thick Biface or Blank. Failures are principally due to the inability to thin because of stepped fractures, hinge fractures, end shock, platform collapse and perverse fracture (Crabtree 1972:81).

Stage 3 (37 specimens; Fig. 20,A-F)

These bifaces exhibit a much greater degree of thinning and display a more intentional form. Fractures are readily identified as being associated with the thinning process. For example, perverse, end shock (Fig. 20,B,C) and overshot ( $F i g .20, E, F$ ) are a.11 represented and a 11 but two of the specimens are broken. This group compares closely in technology to Patterson's $(1977: 40,41)$ Stage 3 Thinned Blank. 
TABLE 4. DEBITAGE, BIFACE FAILURES AND CORES: PROVENIENCE AND METRIC DATA.

Class

Stage 1, Bifaces

Stage 2, Bifaces
Provenience

41 LK $56 /$ T1

41 LK $56 / \mathrm{Tl}$

41 LK $56 /$ T1

41 LK $56 /$ T1

41 LK $56 /$ T2

41 LK 56/T2

41 LK $56 /$ T2E

41 LK 56/T2W

41 LK $56 / 0$

41 LK 90/1

$41 \mathrm{MC} 70 / \mathrm{T} 2$

41 MC $70 / T 2$

41 MC $70 / T 3$

41 MC $70 / T 3$

41 MC $70 / T 4$

41 MC $70 / \mathrm{T} 4$

41 MC 60/1

41 MC 60/1

41 MC $60 / 2$

41 MC $87 / 33$

41 MC $87 / 35$

41 MC $87 / 35$

41 MC $87 / 35$

$41 \mathrm{MC} \cdot 87 / 41$

41 MC $183 / 79$

41 MC $184 / 12$

41 MC $187 / 0$

41 MC 188/0

41 LK $56 / 11$

41 LK 56/T3

41 MC $60 / 7$

41 MC $60 / 1$

41 MC $70 / T 2$

41 MC 70/T3

41 MC $70 / T 3$

41 MC $70 / T 3$

41 MC $70 / T 3$

41 MC 70/T4

41 MC 70/T4

41 MC $70 / T 4$

41 MC $70 / T 4$

41 MC $87 / 44$

41 MC $87 / 29$

41 MC $181 / 0$

41 MC $183 / 5$
Dimension Width Thickness Weight

63

59.3

16

81

57

70

51

60

49

94.3

57

56

65

77.2

60

59

43

59

30

43

46

37

50.2

49

44

46

44

60

43

46

38

47

38

65

65

59

64

61

66

31

62

55

41

40

50

48

62

43

\section{4}

$39 *$

60

32

70

41

60

56

36

37

59

57

24

57

53

57

85

82
38

41

59

60
26

20

17

21

11

21

34

15

23.0

28

19

15

29

19

17

31

10

20

14

19

30

20

20

20

18

19

12

\section{6}

$23^{*}$

15

25

14

22

14

16

14

24

14

14

20

19

16

18
69.5

148.2

80.3

35.0

86.0

12.5

44

62

25.5

108.2

62.5

33.0

44.3

59.8

71.4

22.5

105.2

25.2

46.1

15

92.6

54

41.1

54.6

56.0

69

20.0

35.5

22.0

25.7

25.7

75.5

26.6

49.9

16.7

23.7

20.2

65.1

13.5

34.4

37.7

37.7

82.2

96.3

*measurement for partial specimen 
TABLE 4. (continued)

\section{Class}

Stage 2, Bifaces $\left(\operatorname{con}^{\prime} t\right)$

Stage 3, Bifaces
Provenience

41 MC $183 / 35$

41 MC $183 / 33$

$41 \mathrm{MC} \mathrm{184/T1}$

41 MC 184/T2

41 MC $184 / \mathrm{T} 2$

41 MC 184/1

41 MC $184 / 1$

41 LK 56/0

41 LK 56/T2E

41 LK 56/T2E

41 LK 56/T2E

41 MC 20

41 MC 60

$41 \mathrm{MC} 70 / \mathrm{T} 2$

41 MC $70 / T 3$

$41 \mathrm{MC} 70 / \mathrm{T3}$

$41 \mathrm{MC} 70 / \mathrm{T3}$

$41 \mathrm{MC} 70 / \mathrm{T3}$

41 MC $70 / T 4$

41 MC $70 / T 1$

41 MC $87 / 29$

41 MC $87 / 29$

41 MC $87 / 35$

41 MC $87 / 35$

41 MC $87 / 35$

41 MC $87 / 35$

41 MC $87 / 35$

41 MC $183 / 7$

41 MC $183 / 7$

41 MC $183 / 7$

41 MC $183 / 7$

41 MC 183/16

41 MC $183 / 32$

41 MC $183 / 32$

41 MC 183/35

41 MC 183/35

41 MC $183 / 35$

41 MC $183 / 37$

41 MC 183/37

41 MC $184 / 4$

41 MC $184 / 12$

41 MC $184 / 12$

41 MC $186 / 5$

41 MC 188

Stage 4, Bifaces
41 LK $90 / 5$

41 MC $60 / 6$

41 MC $60 / 6$

Dimension Width Thickness Weight

57

52

53

65

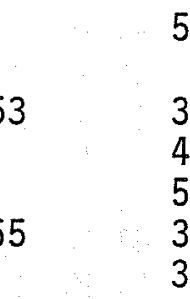

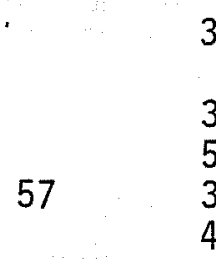

23

49

39

47

32

52

29

41

24

32

40

38

\section{9}

40

39

52

67

35

40

30

26

42

32

46

42

30

28

45

32

44

25
$67 \quad 31$
$\quad 30$

$\begin{array}{ll}23 & 74.1 \\ 12 & 11.6 \\ 17 & 27.8 \\ 14 & 21.0 \\ 18 & 58.7 \\ 19 & 39.0 \\ 11 & 23.3\end{array}$

26.3

13.9

18.9

31.1

24.5

27.7

12.8

8.2

18.4

23.0

24.5

14.3

37.7

9.6

21.5

4.6

13.5

16.1

19.4

28.1

26.8

23.8

38.5

5.9

31.7

12.1

7.6

43.6

15.0

29.9

13.4

8.0

9.9

15.4

11.7

11.0

29.3

10.6

24.1 
TABLE 4. (continued)

Class

Stage 4, Bifaces $\left(\operatorname{con}^{\prime} t\right)$
Provenience Dimension Width Thickness Weight

41 MC $70 / T 1$

41 MC $87 / 29$

41 MC $87 / 33$

41 MC $87 / 33$

41 MC $87 / 41$

41 MC $183 / 32$

41 MC $183 / 32$

41 MC $183 / 32$

41 MC $186 / 10$
37

27

18

21

26

25

28

20
12.8

11.8

4.2

7.9

8.5

11.1

4.2

5.6

3.1

Cores

Cortex Platform

$\begin{array}{llll}41 & \text { LK } & 56 / \text { T1 } & 51 \\ 41 & \text { LK } 56 / \text { T1 } & 50 \\ 41 & \text { LK } 56 / \text { T1 } & 70 \\ 41 & \text { LK } 56 / \text { T1 } & 65 \\ 41 & \text { LK } 56 / \text { T1 } & 59 \\ 41 & \text { MC } 60 / 7 & 69 \\ 41 & \text { MC } 70 / \text { T1 } & 66 \\ 41 & \text { MC } 70 / 11 & 59 \\ 41 & \text { MC } 183 / 34 & 86\end{array}$

Prepared Platform

41 LK 19/21

41 LK 56/T1

41 LK $56 /$ T1

41 MC $60 / 5$

41 MC $60 / 5$

41 MC $183 / 19$

41 MC $183 / 34$

86

75

77

60

94

46

106

Split Cobble Platform

$\begin{array}{llr}41 & \text { LK } 56 / \text { T1 } & 80 \\ 41 & \text { LK } 56 / \text { T3 } & 39 \\ 41 & \text { LK } 56 / \text { T3 } & 48 \\ 41 & \text { LK } 56 / T 3 & 39 \\ 41 & \text { LK } 56 / \text { T3 } & 48 \\ 41 & \text { LK } 56 / \text { T3 } & 51 \\ 41 & \text { LK } 56 / \text { T3 } & 53 \\ 41 & \text { MC } 60 / 2 & 100 \\ 41 & \text { MC } 60 / 2 & 75 \\ 41 & \text { MC } 61 / 0 & 68 \\ 41 & \text { MC } 70 / T 1 & 61 \\ 41 & \text { MC } 70 / T 2 & 64 \\ 41 & \text { MC } 70 / T 2 & 54 \\ 41 & \text { MC } 70 / T 3 & 65 \\ 41 & \text { MC } 70 / \text { T4 } & 107 \\ 41 & \text { MC } 87 / 42 & 92 \\ 41 & \text { MC } 87 / 42 & 25 \\ 41 & \text { MC } 183 / 19 & 57 \\ 41 & \text { MC } 183 / 33 & 81\end{array}$


TABLE 4. (continued)

\begin{tabular}{|c|c|c|}
\hline Class & Provenience & Dimension \\
\hline \multicolumn{3}{|l|}{$\underline{\text { Cores }}\left(\operatorname{con}^{\prime} t\right)$} \\
\hline Interior Platform & $\begin{array}{lll}41 & \text { LK } & 56 / T-1 \\
41 & \text { LK } & 56 / T-1 \\
41 & \text { LK } & 56 / T-1 \\
41 & \text { LK } & 56 / T-W 2 \\
41 & \text { LK } & 56 / T-3 \\
41 & \text { LK } & 56 / T-3 \\
41 & \text { LK } & 56 / T-3 \\
41 & M C & 62 / 0 \\
41 & M C & 60 / 2 \\
41 & M C & 60 / 2 \\
41 & \text { MC } & 60 / 2 \\
41 & \text { MC } & 60 / 2 \\
41 & \text { MC } & 60 / 0 \\
41 & \text { MC } & 60 / 5 \\
41 & \text { MC } & 60 / 5 \\
41 & \text { MC } & 70 / T 1 \\
41 & M C & 70 / T 2 \\
41 & M C & 70 / T 3 \\
41 & M C & 70 / T 3 \\
41 & M C & 70 / T 4 \\
41 & \text { MC } & 70 / T 4 \\
41 & \text { MC } & 87 / 42 \\
41 & M C & 183 / 32 \\
41 & \text { MC } & 183 / 32\end{array}$ & $\begin{array}{l}115 \\
75 \\
52 \\
40 \\
58 \\
54 \\
55 \\
78 \\
77 \\
60 \\
73 \\
60 \\
69 \\
92 \\
62 \\
69 \\
53 \\
70 \\
53 \\
54 \\
76 \\
64 \\
47 \\
70\end{array}$ \\
\hline Variable Platform & 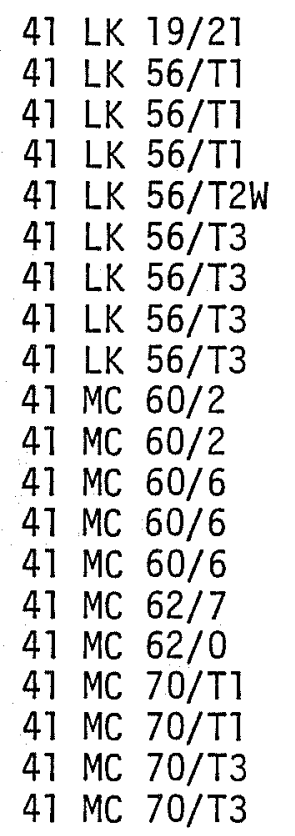 & $\begin{array}{r}70 \\
72 \\
77 \\
58 \\
89 \\
86 \\
47 \\
58 \\
57 \\
81 \\
61 \\
84 \\
84 \\
55 \\
62 \\
112 \\
72 \\
48 \\
72 \\
66\end{array}$ \\
\hline
\end{tabular}


TABLE 4. (continued)

Class

Provenience Dimension

Cores $\left(\operatorname{con}^{\prime} t\right)$

Variable Platform

$\begin{array}{lll}41 & \text { MC } 70 / \mathrm{T} 4 & 48 \\ 41 \text { MC } 70 / \mathrm{T} 4 & 55 \\ 41 \text { MC } 183 / 33 & 75 \\ 41 \text { MC 183/33 } & 76 \\ 41 \text { MC 184/T2 } & 68 \\ 41 \text { MC 184/T2 } & 86\end{array}$

Stage 4 (11 specimens; Fig. 20,G-J)

The Stage 4 bifaces are thinned and have form but lack the final step of lateral edge trimming and shaping. All but one are broken and in only four cases do the breaks appear to be associated with thinning. The forms vary from straight, rounded to lozenge-shaped bases. One specimen (Fig. 20,H) is an arrow point preform.

Cores (84 specimens)

Cores are cobbles or nodules of chert, quartzite, silicified wood or other siliceous material which exhibit one or more flake removals. The Choke Canyon sample has been sorted primarily on the basis of striking platform location or locations. Since the striking platform and configuration of the outer surface is crucial in systematically removing flakes having desired characteristics as well as providing the major controls in shaping a core, the platform locations are emphasized in the study.

As mentioned earlier, the raw materials consist of chert cobbles selected from either late Pleistocene or Holocene gravel deposits. The Holocene deposits are mostly found along the contemporary gravel bars and the aggregates here presumably contain a large amount of reworked Pleistocene materials. Examining the cortex the cobbles selected for raw material provides at least a minimum of information on where this selection took place. Most of the cores are rounded to subrounded nodules with a battered, cherty cortex exhibiting literally hundreds of smal1 percussor scars resulting from stream transport and contact with other similarly hard stones. The cortex is normally much darker than the interior chert and does not give an adequate indication of quality.

Another source of chert must be coming from older cobble outcrops iying above the more recent Pleistocene and Holocene deposits. This is an assumption based on the presence of specimens with a different kind of cortex. The cortex in this group is characteristically a chalky chert which is lighter than the interior. The cortex exhibits thermal spall scars sometimes to the point that these scars cover much of the outer surface. These thermal spalls were 

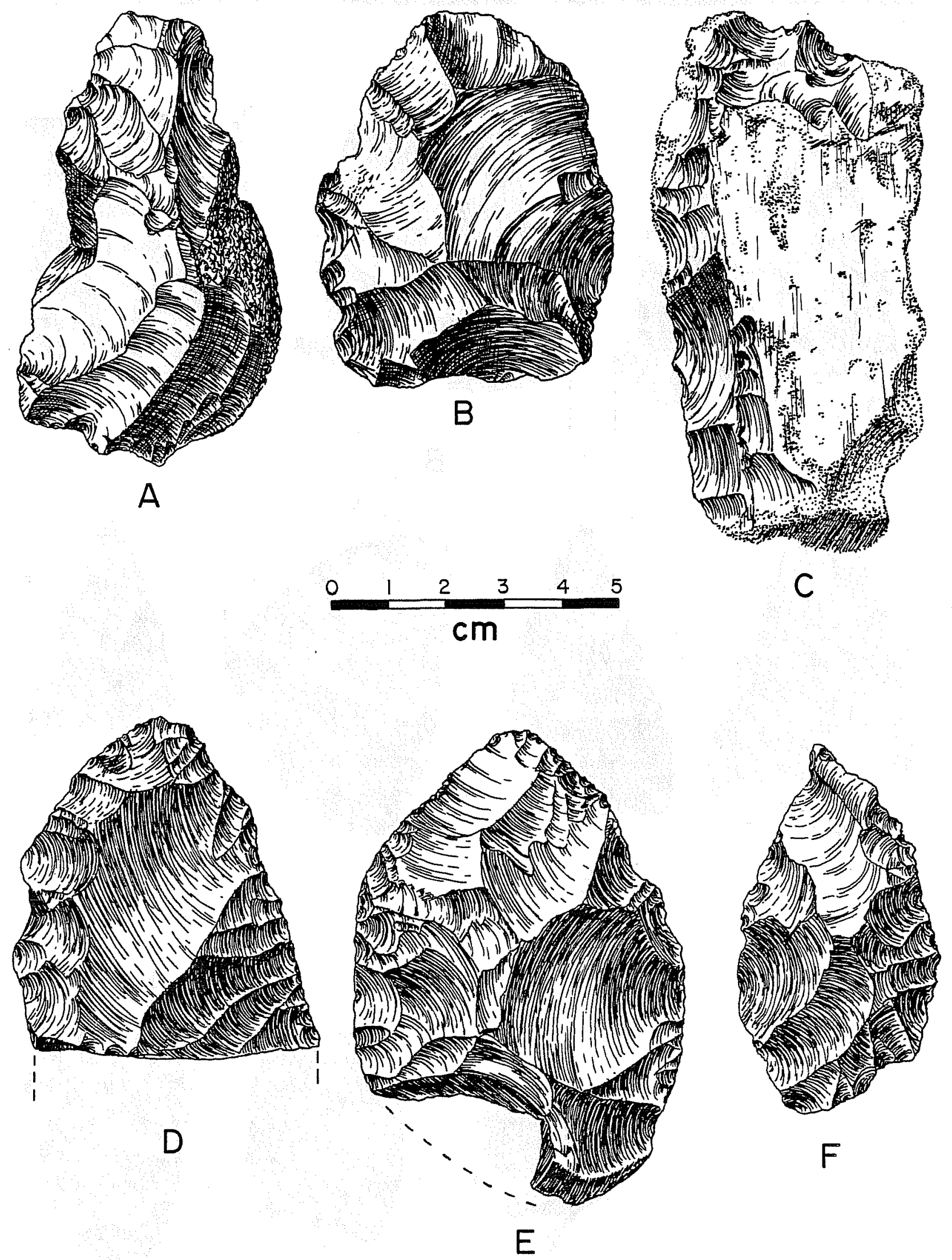

KR'BI

Figure 19. Biface Failures. A-C, Stage 1; D-F, Stage 2. 

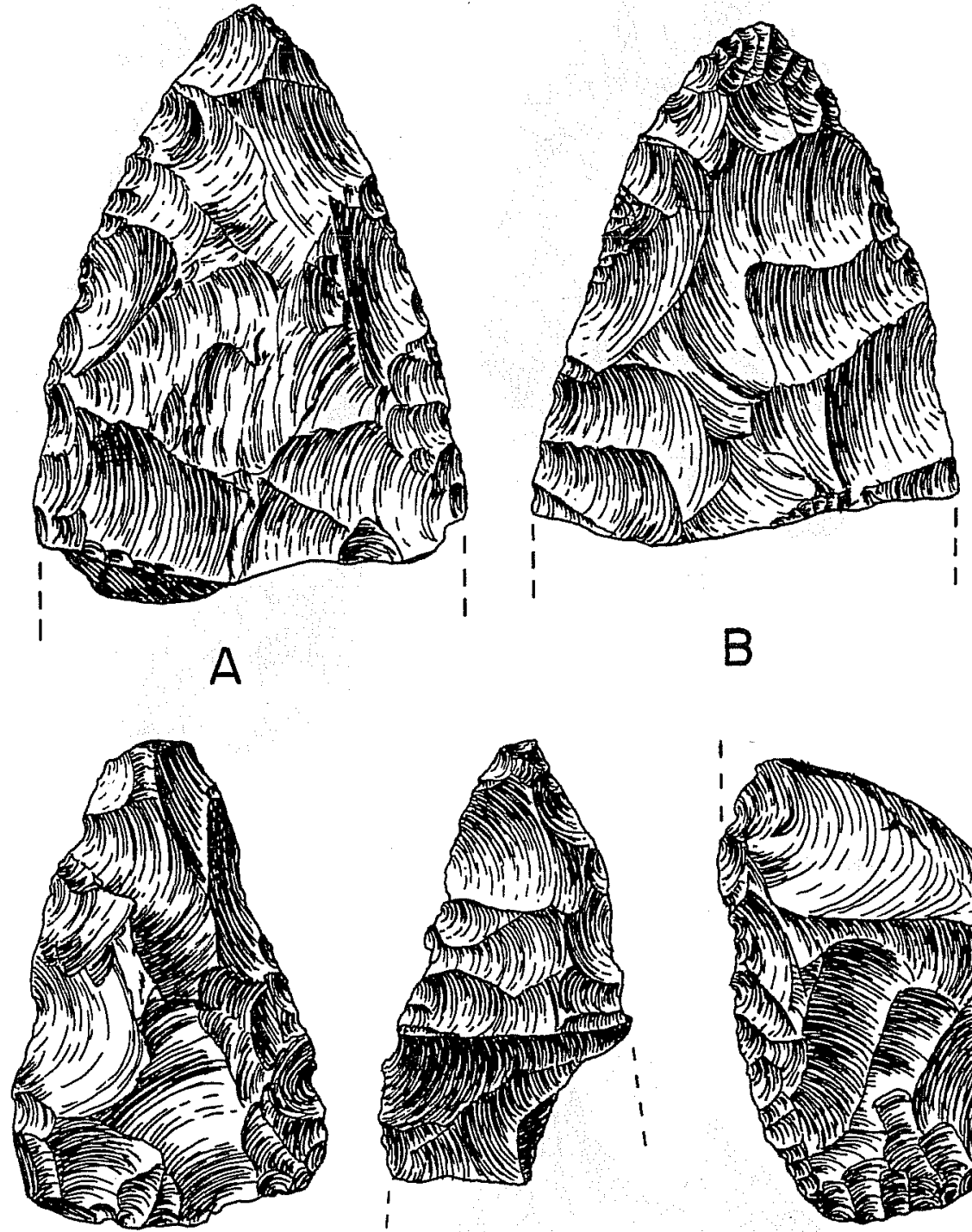

E
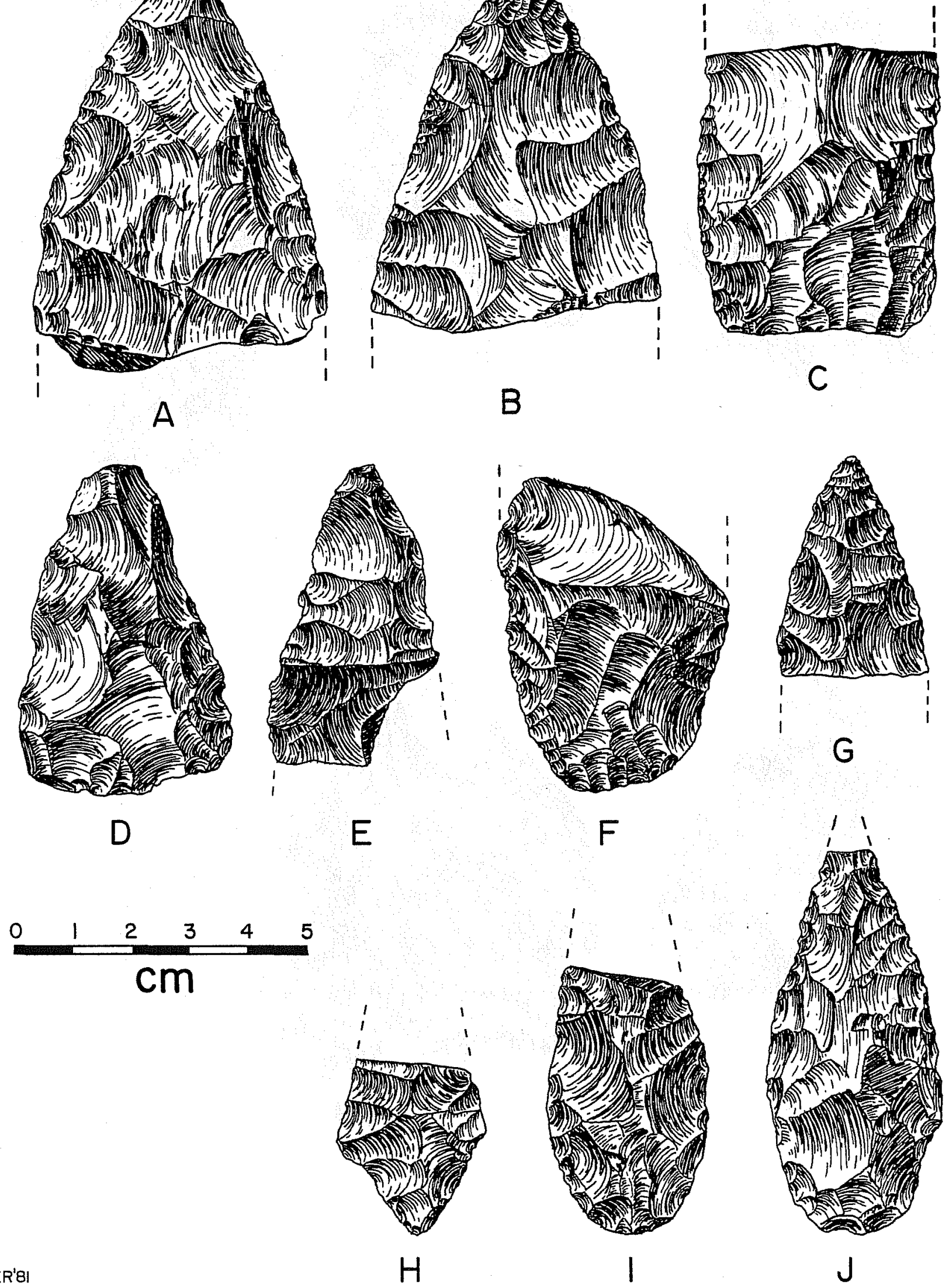

Figure 20. Biface Failires. A-F, Stage 3; G-J, Stage 4 . 
probably caused by frost fracturing and post-date the stream battering which is still evident on some specimens. Thermal weathering of the cortex is a characteristic of Uvalde Gravels seen in the Blackland Prairies and which have not been reworked by more recent stream action ( $H$. J. Shafer, personal observations). Their occurrence here may indicate the presence of in situ Uvalde Gravels in the Choke Canyon district. These interpretations are based on laboratory observations and need to be examined in the field.

The cores are divided into five descriptive groups: prepared platform, cortex platform, split cobble interior platform, interior platform, and variable platform (cortex and prepared or cortex and interior). It is quite possible that these cores represent the end of a reduction continuum that could have included splitting a cobble and using one or more interior platforms. The sorting was done, however, on the basis of the platforms which are presentiy observable.

\section{Cortex-Platform (9 specimens)}

These cores are reduced segments of cobbles exhibiting only cortex platform removals. The intent appears to have been to reduce the core into usable flakes.

\section{Prepared Platform (7 specimens)}

These cores exhibit one or more flake removals designed to establish a suitable striking platform for subsequent flaking. For example, a flintknapper would remove the end of a cobble and use the newly created facet as the striking platform to remove a series of flakes. The suitable flakes would presumably then be used either as tools or as blanks.

\section{Split Cobble Prepared Platform (17 specimens)}

As noted in the discussion of Raw Materials, one technique of circumventing the problem of establishing a suitable striking platform on a rounded cobble was to split the core with a massive, direct blow (Hester 1975). Many examples of this technique are in the flake and core sample. The cobble halves were often further reduced by using the newly created facet as a striking platform.

Interior platforms (2 specimens)

These are interior segments of cores that evidence one or more striking platforms. Most are considerably reduced and few even retain traces of cortex.

Variable Platforms (27 specimens)

These cores all exhibit a combination of cortex and prepared interior striking platforms. They probably best illustrate the basic strategy of reduction for these cores, that is, strike wherever the conditions are best for achieving the desired results whether it is on the cortex or a faceted surface. 


\section{Discussion}

The strategies for reducing the rounded cobbles into suitable blanks, flakes, or core tools vary and were probably dictated by the nature of the core. Flintknappers will almost always change the reduction strategy as needed to either conform to a successful sequence of flake removals or to recover from a mistake or problem. Indeed when considering a raw material source such as the Choke Canyon lithic materials, one would hardly expect to find a consistent, single trajectory strategy as one might find in an ideal flow diagram of lithic reduction. An inspection of the artifact sample reveals the diversity in the end products of the various reduction strategies utilized over a several thousand year time span.

There is one particular characteristic that has been observed on sma11, unusually thoroughly reduced cores from both Choke Canyon and a nearby Lignite Mine area in Atascosa County. Small cores often display numerous poorly directed percussor marks on faceted surfaces. These marks occur at considerable distances from the edge and do not always seem to be the product of an attempt to remove a flake; if so the knapper was unskilled and was quite consistent in not hitting near enough to the edge to cause a flake removal. The function of these interesting artifacts is unknown. They are recorded from 41 LK 56 and 47 MC 70.

\section{Flakes (3018 specimens)}

Flake samples constitute the only cultural remains collected from certain Choke Canyon sites. The reason for this is that aside from occasional mussel or snail shells, which were not collected except from excavated units, flakes were the only other tangible cultural evidence observed.

The flakes were sorted on the basis of their relative position on the core. Primary flakes were the first flakes removed from a core and retain cortex over the entire outer surface. Secondary flakes retain a portion of the cortex on the outer surface whereas tertiary flakes retain no trace of cortex. Chips are flake fragments that lack the bulbar end. The term "chunk" is used for the lack of a better word to designate chert nodule sections that are the product of lithic reduction but lack either clearly defined flake removals as do cores or attributes indicating that they are flake fragments.

The striking platforms of the secondary and tertiary flakes are also divided into subcategories: cortex (consisting of the cortex surface of the parent core); single facet (a flat, interior surface); multiple facet (two or more facets on the platform); and lipped flakes (flakes removed with a cushioned blow during the process of bifacial thinning). The multiple platform flakes were sorted on the basis of relative size in the assemblage in which they occur. Many of the smal1, multiple faceted platform flakes are probably the byproducts of bifacial thinning although their functional association cannot be determined for certain.

Tables charting the provenience of the flakes are filed at CAR. The tables are available to interested researchers, but are not reproduced here because most of 
the samples are much too small for meaningful site function and site correlation studies. Several variables may affect the nature of the lithic debitage present at a site. For example, the site's proximity to lithic resources may determine the relative degree of "staging" in reducing raw materials (Shafer 1969:94), the number and frequency of manufacturing trajectories represented in the debitage assemblage and the kinds of activities performed at one time or over time at a site in which the manufacture of lithic tools was necessary.

The data accumulated during our study should be viewed as providing information on kinds and nature of the activities carried out at the respective sites and which lead to the production and discarding of flake debitage. It would have been plausible perhaps had we proposed certain hypotheses regarding site function and settlement behavior and tested these hypotheses. For example, we could propose that sites yielding large (relative to the other frequencies) numbers of cortex flakes were either resource procurement sites or sites which were located very near or at resource procurement outcrops. At least five sites (41 MC 56, 41 MC 60, 41 MC 62, and 41 MC 173) would fall into this cluster. We would like to demonstrate, however, that the flake samples are not necessarily reflective of the activities performed at the sites. A comparison of the sample of biface thinning flakes from 41 LK 56 (4 of 216 or less than $0.5 \%$ ) with the biface failures from the same site (15 of 20 bifaces or $75 \%$ ) illustrated a very marked disproportionate frequency of biface thinning flakes. We would expect a much higher frequency of thinning flakes than were actualiy identified.

The low frequency of biface thinning flakes was probably due to several factors including sampling procedures, the nature of the flake classification and the problems of identifying all biface thinning flakes. Many secondary and tertiary flakes are undoubtedly the products of bifacing but due to the variation in the removal techniques and variability in the platforms, their identity becomes obscured by the more rigid taxonomic rather than functional classification scheme employed for the flakes.

The problems we encountered in our Choke Canyon study of interpreting small flake samples should be taken into consideration in designing future sampling procedures and classification schemes. The classification schemes for flakes, bifaces, and cores should be internally consistent and logical in terms of the problems addressed. Our flake sorting was in conformance with the UTSA Choke Canyon classification and was used with the intent to make the collections comparable. If the aim is to use the flake data independent of other artifact categories, then an analytical classification for flakes is perhaps justified. If the intent is to integrate the flakes with other artifact categories in efforts to look for internal relationships and integrating the various lithic classes into behavior sets, then the overall classification must be internally consistent.

The decision was made to divide the artifact samples into two broad classes, implements and debitage in order to provide immediate functional information about each site. To a degree, we feel that this was successful. Beyond this level of interpretation, however, we do not feel comfortable that the core and flake classification represents the reality of the sample. Also, we do not feel that our samples were sufficient to investigate more specific behavioral problems. 


\section{RECOMMENDATIONS}

Six sites of the 19 tested or collected by the Texas A\&M Anthropology Research Laboratory are being recommended for further, more detailed work. Five of the six sites are situated within the Elm Creek/Frio River site complex which will be described in some detail forthwith. One site, 41 LK 56, was initially a surface collection site and it is now also being recommended for limited testing.

While it is recognized that it is somewhat unusual to recommend site complexes for investigation, in the case of the cluster of localities adjacent to the Elm Creek/Frio River junction an exception must be made for the reasons now presented. At the time initial work was conducted, only hand excavation was carried out. We now feel that more extensive and deeper excavations will clarify several of the tentative conclusions which have been reached concerning these clusterings of sites. These conclusions are presented in the short discussion which follows. The five sites selected are considered representative of all the sites in the immediate area. The sites (41 MC 60, 41 MC 61, 41 MC 62, 41 MC 63, 41 MC 73, 41 MC 173, 41 MC 180, 41 MC 181, 41 MC 182, 41 MC 183, 41 MC 184, 41 MC 185, 41 MC 186, 41 MC 187, 41 MC 188) situated along Elm Creek, north of the Frio River represent a continuous cultural complex. As noted previously, the sites were somewhat arbitrarily divided from one another on the basis of physical or topographic features.

Following analysis of the cultural material from all the sites, it was, for instance, apparent that each of the sites immediately adjacent to the Frio River was similar in relation to tool assemblage and implied periods of occupation. The sites further along the upper reaches of Elm Creek display a lithic assemblage with significantly higher percentages of cores and primary flakes than the downstream sites. As an example of the differentiation, in an analysis of 1 ithic material types, it was discovered that 92.3 percent of the stone types occurring at the upstream sites were present at the downstream localities; however; 7.7 percent of the lithic material types occurred only at downstream sites, and not in any significant percentage at the upstream localities. It would appear that the upstream sites were quarry sites, materials roughly sorted from the geologic strata, initially prepared cores with a high percentage of exhausted cores present in the assemblage.

The 12 sites which make up the Elm Creek/Frio River complex represent obviously only a smal1 percentage of the total number of sites throughout the reservoir area. The interrelationships between the sites are assumed on the basis of similar assemblages and materials utilized. There is no practical way at this time to determine the actual periods of occupation for the sites. It is sufficient to say that the diagnostics recovered indicate occupations beginning in the Middle Archaic Period and extending up through the Neo-American or Post-Archaic Period; however, the duration of each occupation remains in question.

In all probability, the occupations represent a sporadic exploitation of the same locality over a long span of time. The close accessibility of the downstream sites to the quarry locations, and the fact that the sites were situated as to take full advantage of both riparian and upland biota, point to their optimum placement. 
It is possible that additional cultural complexes of a similar nature can be identified throughout the reservoir area. The close physical proximity of the sites enabled a detailed comparison of materials recovered from each site, al though requirements for mitigation varied from site to site. As the artifact assemblage for each site indicated there is little differentiation from location to location, other than the previously mentioned differences noted between the upland and downstream sites. The downstream complex must be viewed as a continuous exploitation and occupation zone. Given the clustering of sites at several localities along the Frio, the apparent patterning is one of consistent exploitation along the river, close to a constant water source and within walking distance to several of the principal plant communities within the area. Further investigation, and the combining of results from the various investigative teams, may reinforce the conclusions presented here, which is the definitive reason for the recommendation that the following five sites be subjected to limited testing: 41 MC 60, 41 MC 63, 41 MC 186, 41 MC 187 , and 41 MC 188.

The aforementioned recommendations for the sites in the Elm Creek are is predicated on several factors. One, that the recommendations take into consideration the previous minimal and/or limited testing already conducted on the sites. Second, that the five sites under evaluation are representative of the remaining seven in the immediate vicinity. Third, that limited testing will allow for the addressing of specific questions concerning stratigraphy which were not addressed in the initial effort. This is to be accomplished through most extensive hand excavations and the selective use of backhoe trenching. Fourth, and last, it is of some importance that a more extensive excavation be conducted at the lowland sites in order to determine not only the absolute depth of the sites, but whether or not any of these sites still possess features which will lend data for conclusions concerning the seasonality or nature of occupations in the area.

The previously cited rationale for the recommendations of the sites in the Elm Creek locale also partially apply to 47 LK 56. The northern portion of the site has not been subjected to erosion as has the southern section; therefore, a possibility exists that features may still remain intact at the site. Additiona11y, 41 LK 56 represents a site so located as to take maximum advantage of both high and low land resources. The surface collection and reconnaissance of the site showed the presence of burned rock and diagnostics, plus several other tool types, that would indicate the site locality had been continually exploited for a long period of time. In conclusion, the nature of the artifact assemblage and the locality of the site would indicate a probability for more data retrieval directly pertinent to questions of length of occupation in the canyon area and exploitative strategies being utilized therein.

Sites not recommended for further testing were so designated for three primary reasons. One, they were similar to recommended sites, and in certain instances represented, in al1 probability, actual portions of recommended sites. Second, they did not upon initial evaluation, display any depth or surface clusterings of artifactual material. Third, they were heavily disturbed by roads cutting across them, erosion, or agricultural activity. 
Of the six sites chosen for further testing, all warrant minimum consideration for inclusion in the National Register of Historic Places. . It is understandable that this evaluation does not require preservation of the resource on a long-term basis. But it does stress the necessity for further work on the sites recommended. Listed below are the justifications of the recommendations.

\section{Evaluation and Recommendation}

41 LK 19: tested; maximum depth $(30 \mathrm{~cm})$; disturbed by road and agricultural activity; no further work recommended.

41 LK 90: tested; minimal artifactual material; heavily dissected; no further work recommended.

41 LK 56: surface collected; diagnostics and burned rock present; minimal disturbance; recommended for 1 imited testing.

41 MC 60: surface collection and minimal tested; erosion to the northern edge; minimal disturbance to site; artifact clusters and diagnostics; recommended for 1 imited testing.

41 MC 61: locality heavily disturbed; no further work recommended.

41 MC 62: surface collected and minimal tests to determine depth (maximum $40 \mathrm{~cm}$ ); heavily disturbed by road cutting and erosion; no further work recommended.

41 MC 63: surface collected; limited testing; two occupation zones identified (maximum depth estimated $110 \mathrm{~cm}$ ); some disturbance to western edge by arroyo cut; road cut through site; recommended for further work to more fully define stratigraphy and relationship with 41 MC 186, 41 MC 187, and 41 MC 188; 1imited testing recommended.

41 MC 70: surface collected; heavily dissected by road cutting and agricultural utilization; no further work recommended.

41 MC 75: no access.

41 MC 87: surface collected and limited testing; some disturbance through agricultural utilization; shallow (maximum depth $40 \mathrm{~cm}$ ); artifacts highly scattered; no further work recommended.

41 MC 173: not found as such; included in a11 probability in surface collection of 41 MC 180 and 41 MC 181.

41 MC 174: inaccessible to survey crew.

41 MC 178: surface collected; road cutting and heavy agricultural utilization; artifactual material highly scattered; no further work recommended. 
41 MC 180: surface inspected; road cutting and heavy agricultural utilization; artifactual material highly scattered; no further work recommended.

41 MC 181: surface collected and minimal testing; maximum depth $60 \mathrm{~cm}$; heavy vegetation along western edge; road cutting and significant agricultural utilization; artifact return minimal; no further work recommended.

41 MC 183: surface collected and minimal testing; maximum depth $70 \mathrm{~cm}$; heavy agricultural utilization; no further work recommended.

41 MC 184: surface collected; significant erosion to south and southeast road cutting; artifactual material highly scattered; no further testing recommended.

41 MC 186: surface collected and minimal testing; some disturbance to eastern edge through agricultural utilization; maximum depth $110 \mathrm{~cm}$; two possible occupation layers; limited testing recommended to determine stratigraphy, depth and relationship to 41 MC 63.

41 MC 187: surface collected and minimal testing; erosion to western edge; maximum depth $60 \mathrm{~cm}$; artifactual materials clustered; limited testing recommended to determine the relationship to 41 MC 186 .

41 MC 188: surface collected and minimal testing; erosion significant to western edge; depth $45 \mathrm{~cm}$; artifactual materials clustered; further work recommended to determine reason for high numbers of burned rock and to establish relationship to 41 MC 186; lịmited testing recommended. 


\section{REFERENCES CITED}

Binford, L. R. and G. I. Quimby

1963 Indian Sites and Chipped Stone Materials in the Northern Lake Michigan Area. Fieldiana Anthropology 36(12):277-307.

Blair, F. W.

1950 The Biotic Provinces of Texas. The Texas Journal of Science $2(1): 230-250$.

Bradley, B. A.

1975 Lithic Reduction Sequences: A Glossary and Discussion. In Lithic Technology: Making and Using Stone Tools (ed. Ear1

Swanson):5-14. Mouton Publishers, The Hague, Netherlands.

Butzer, K. W.

1971 Environment and Archeology: An Ecological Approach to Prehistory. Aldine Publishing Co., New York.

Campbe11, T. N.

1975 The Payaya Indians of Southern Texas. Southern Texas Archeological Association Special Publication 1. San Antonio.

Campbe11, T. N. and T. J. Campbe11

1981 Historic Indian Groups of the Choke Canyon Reservoir and Surrounding Area, Southern Texas. Center for Archaeological Research, The University of Texas at San Antonio, Choke Canyon Series: volume 1.

Collins, M. B.

1975 Lithic Technology as a Means of Processual Inference. In Lithic Technology: Making and Using Stone Tools (ed. Ear1 Swanson): 15-34. Mouton Publisher, The Hague, Netherlands.

Crabtree, D. E.

1972 An Introduction to Flintknapping. Idaho State University Museum Occasional Papers 28. Pocate170.

Dering, J. P.

1979 Pollen and Plant Macrofossil Vegetation Record Recovered from Hinds Cave, Val Verde County, Texas. Masters Thesis, Texas A\&M University, College Station. 
Dering, J. and H. J. Shafer

1976 Analysis of Matrix Samples from a Crockett County Shelter: A Test for Seasonality. Bulletin of the Texas Archeological Society 47:209-230。

Evans, G. L.

1941 Artifact Occurrence in the Second Terrace of the Rio Grande in Starr County, Texas (abstract). Bulletin of the Geological Society of America 52(12), Pt。2:1998-1999.

Fenneman, N. M.

1938 Physiography of Eastern United States. McGraw-Hi11, New York.

Fox, D., R. J. Mallouf, N. O'Malley, and W. M. Sorrow

1974 Archeological Resources of the Proposed Cuero I Reservoir, DeWitt and Gonzales Counties, Texas. Archeological Survey Report 12. Texas Historical Commission (Office of the State Archeologist Report 16)。State Building Commission, Austin。

Godfrey, C. L., G. S. McKee, and H. Oaks

1973 General Soil Map of Texas. Texas A\&M University. Texas Agricultural Experiment Station, College Station.

Hester, T. R.

1971 Archeological Investigations at the La Jita Site, Uvalde County, Texas. Bulletin of the Texas Archeological Society 47:51-148.

1975 Chipped Stone Industries on the Rio Grande PTain of Texas. The Texas Journal of Science 26(1-2):213-222.

1976 Hunters and Gatherers of the Rio Grande Plain and the Lower Coast of Texas. Center for Archaeological Research, The University of Texas at San Antonio.

1977 The Current Status of Paleoindian Studies in Southern Texas and Northeastern Mexico。 In Paleo-Indian Lifeways, Eileen Johnson (ed.). The Museum Journal, XVII:169-186. West Texas Museum Association, Texas Tech University, Lubbock.

1980 Digging into South Texas Prehistory. Corona Publishing Company, San Antonio.

Hester, T, R, and T. C. Hill, Jr.

1971 An Initial Study of a Prehistoric Ceramic Tradition in Southern Texas. Plains Anthropologist 16(53):195-203. 
1975 Some Aspects of Late Prehistoric and Protohistoric Archaeology in Southern Texas. Center for Archaeological Research, The university of Texas at San Antonio, Special Report 1.

Hester, T. R. and R. C. Parker

1970 The Berclair Site: A Late Prehistoric Component in Goliad County, Southern Texas. Bulletin of the Texas Archeological Society $41: 1-23$.

Hester, T. R. and H. J. Shafer

1975 An Initial Study of Blade Technology on the Central and Southern Texas Coast. Plains Anthropologist 20(60):175-186.

Hester, T. R., L. 0. White, and J. White

1969 Archeological Materials from the Oulline Site (41 LS 3) and Other Sites in La Salle County, Southwest Texas. The Texas Journal of Science 21(2):131-166.

Hi11, T. C. and To R. Hester

1971 Isolated Late Prehistoric and Archaic Components at the Honeymoon Site, Southern Texas. Plains Anthropologist 15(54):52-59。

Inglis, J. M.

1964 A History of Vegetation on the Rio Grande Plain. Texas Parks and Wildlife Department Bulletin 45. Austin.

Johnson, $E_{0} H$.

1931 The Natural Regions of Texas. The University of Texas Bulletin 3113. Austin.

Johnson, L. Jr.

1967 Toward a Statistical Overview of the Archaic Cultures of Central and Southwestern Texas. Texas Memorial Museum Bulletin 12. Austin。

Johnson, L., Jr., D. A. Suhm, and C。 D. Tunne11

1962 Salvage Archeology of Canyon Reservoir: The Wunderlich, Footbridge and 0blate Sites. Texas Memorial Museum Bulletin 5. Austin。

Kearney, T, H. and R. H. Peebles

1960 Arizona Flora (2nd ed. with Supplement by John Thomas Howell and Elizabeth McClintock). University of California Press, Berkeley. 
Krieger, A. D.

1944. The Typological Concept. American Antiquity 9(3):271-288.

1956 Food Habits of the Texas Coastal Indians in the Early Sixteenth Century. Bulletin of the Texas Archeological Society 27:47-58.

Lynn, W. M., D. E. Fox, and N。O'Malley

1977 Cultural Resource Survey of Choke Canyon Reservoir, Live Oak and McMullen Counties, Texas. Archeological Survey Report 20 (Office of the State Archeologist). Texas Historical Commission. Austin.

MacDona ld, G. F.

1969 Debert: A Paleo-Indian Site in Central Nova Scotia. Anthropology Papers 16, National Museum of Canada. Ottowa.

Mallouf, R. J., D. E. Fox, and A. K. Briggs

1973 An Assessment of the Cultural Resources of Palmetto Bend Reservoir, Jackson County, Texas. Archeological Survey Report 11. Texas Historical Commission (Office of the State Archeologist) and Texas Water Development Board. Austin.

Newcomb, W. W., Jr.

1961 The Indians of Texas: From Prehistoric to Modern Times. University of Texas Press, Austin.

Nunley, P. and T. R. Hester

1966 Preliminary Archeological Investigations in Dimmit County, Texas. The Texas Journal of Science 18(3):233-253.

1975 An Assessment of Archeological Resources in Portions of Starr County, Texas. Center for Archaeological Research, The university of Texas at san Antonio, Archaeological Survey Report 7.

Odum, E. P.

1971 Fundamentals of Ecology (3rd edition). W. B. Saunders Co. Philadelphia.

Patterson, P. E.

1977 A Lithic Reduction Sequence: A Test Case In the North Fork Reservoir Area, Williamson County, Texas. Bulletin of the Texas Archeological Society 48:53-82. 
Patterson, P. E. and M. M. Ford

1974 Oso Creek Flood Control Project Area, Nueces County, Texas: A Report on the Archeological and Historical Resources. Texas Archeological Survey, Research Report 35.

Ruecking, F. H., Jr.

1955 The Social Organization of the Coahuiltecan Indians of Southern Texas and Northeastern Mexico. The Texas Journal of Science $7(4): 347-388$.

Russe1, R. J.

1945 Climates of Texas. Annals, Association of American Geographers $34: 37-52$.

Sayles, E. B.

1935 An Archeological Survey of Texas. Medallion Papers 17. Gila Pueblo, Globe, Arizona.

Sellards, E. H.

1940 Pleistocene Artifacts and Associated Fossils from Bee County, Texas. Bulletin of the Geological Society of America 51:373-432.

Sellards, E. H., W. S. Adkins, and F. B. Plummer

1958 The Geology of Texas, Volume I: Stratigraphy. Bureau of Economic Geology, university of Texas Bulletin 3232. Austin.

Shafer, H. J.

1969 Archeological Investigations in the Robert Lee Reservoir Basin, West Central Texas. Papers of the Texas Archeological Salvage Project 17.

1973 Lithic Technology at the George C. Davis Site, Cherokee County, Texas. Ph.D. Dissertation, The University of Texas at Austin.

1976 The Consideration of Lithic Refuse at Archeological Sites. La Tierra 3(2):8-10.

Shafer, H. J. and E. P. Baxter

1975 An Archeological Survey of the Lignite Project, Atascosa and McMullen Counties, Texas. Anthropology Laboratory Report 7. Texas A\&M University, College Station.

Shafer, H. J. and V. M. Bryant, Jr.

1977 Archeological and Botanical Studies at Hinds Cave, Val Verde County, Texas. Anthropology Laboratory Special Series 1. Texas A\&M University, College Station. 
Shafer, H. J. and T. R. Hester

1971 A Study of the Function and Technology of Certain Bifacial Tools from Southern Texas. Texas Historical Survey Committee Archeological Report 20.

Shafer, H. J. and R. G. Holloway

1979 Organic Residue Analysis in Determining Stone Tool Function. In Lithic Use Wear Analysis (edited by Bryan Hayden):385-400. Academic Press, New York.

Sorrow, W. M., H. J. Shafer, and R. E. Ross

1967 Excavations at Sti11house Hollow Reservoir. Papers of the Texas Archeological Salvage Project 11.

Suhm, D. A., A. D. Krieger, and E. B. Jelks

1954 An Introductory Handbook of Texas Archeology. Bulletin of the Texas Archeological Society 25.

Suhm, D. A. and E. B. Jelks

1962 Handbook of Texas Archeology: Type Descriptions. Texas Memorial Museum Bulletin 4. Austin.

Vines, R. A.

1960 Trees, Shrubs and woody Vines of the Southwest. The University of Texas Press, Austin.

Wakefield, W. H.

1968 Archeological Surveys of Palmetto Bend and Choke Canyon Reservoirs, Texas. Texas Archeological Salvage Project, Survey Report 5.

Weir, F. A.

1956 Surface Artifacts from La Peridida, Starr County, Texas. Bulletin of the Texas Archeological Society 27:59-78.

Wesolowsky, A. B., T. R. Hester, and D. Brown

1976 Archeological Investigation at the Jetta Court Site (41 TV 151), Travis County, Texas. Bulletin of the Texas Archeological Society: 25-28.

White, J. P.

1968 Fabricators, Outils Écailles or Scalor Cores? Mankind 6(2): 658-660. 
